PART 3

The Low Countries 
Karl Enenkel - 9789004378216

Downloaded from Brill.come4/26/2023 01:36:12PM via free access 


\title{
From Chivalric Family Tree to "National" Gallery: The Portrait Series of the Counts of Holland,
}

ca. $1490-165^{0}$

\author{
Karl Enenkel
}

Strikingly, it was in the very era of the Dutch Revolt that portrait series of the Counts of Holland were printed in large number in the Low Countries. ${ }^{1}$ At first sight, this might seem odd, since the Habsburgs, including the Spanish monarch Philip II, were the owners of the title of Count of Holland, and they were the country's political and military opponents during the Revolt. In the year of his death (1598), Philip gave the Netherlands to his nephew Albert (1559-1621), later Archduke of Austria. This ensured that the title of Count of Holland, and the territorial claim connected with it would remain in Habsburg hands in future. From the Habsburgs's point of view, then, the publishing of a portrait series of the Counts of Holland might have been intended to underpin that claim. Nevertheless, publication of the series did not straightforwardly mean that those responsible for them (authors, artists, publishers and patrons) were opponents of the Revolt or adherents of Philip. It should be borne in mind that the Revolt was an exceedingly drawn-out process, involved several stages, and that its end result - recognition that the seven northern

1 This contribution is a revised, altered and augmented version of my "Van ridderlijke familiegalerij tot 'nationale' portrettengalerij: de reeksen van de graven van Holland, ca. 1490-1650", published as chapter 8 in Enenkel K.A.E. - Ottenheym K.A., Oudheid als ambitie. De zoektocht naar een passend verleden 1400-1700 (Nijmegen: 2017) 205-242. For early modern printed series of the Counts of Holland, cf. Jong J. de, "Gravenportretten in de zestiende en zeventiende eeuw", in Anrooij W. van (ed.), De Haarlemse gravenportretten. Hollandse geschiedenis in woord en beeld (Hilversum: 1997) 78-102. Jan de Jong examines the question of how authentic or realistic the printed portraits were regarded, but does not discuss their political and ideological significance. For the portraits of the counts cf. also Weissman A.W., "De portretten der graven van Holland te Haarlem", Oud-Holland 35 (1917) 61-70. The portrait series in the town hall of Haarlem was researched by Wim van Anrooij, Truus van Bueren, Reindert Falkenburg and Marijke Moijaart, in Anrooij W. van (ed.), De Haarlemse gravenportretten; for this series cf. also Kurtz G.H. (ed.), "De afbeeldingen der graven en gravinnen van Holland op het stadhuis te Haarlem", Jaarboek Haerlem (1958) 40-58. For historical questions regarding the Counts of Holland see, inter alia, Boer D.E.H. de - Cordfunke E.H.P., Graven van Holland. Portretten in word en beeld (880-1580) (Zutphen: 1995).

(C) KARL ENENKEL, 2019 | DOI:10.1163/9789004378216_012

This is an open access chapter distributed under the terms of the prevailing CC-BY-NC-ND License at the time of publication. 
provinces were an independent state - was not foreseen at the outset. Within the Seven Provinces themselves, there was a long period in which there was no clarity on the political course to be charted, not even after the official abjuration of Philip in $1581 .^{2}$ Although the north achieved key military successes between 1574 and 1576 , a number of attempts were made to restore the monarchy, even after 1581, when the Northern Netherlands went actively looking for a suitable replacement prince. The Queen of England and the King of France were among the candidates considered, but ultimately the attempts to secure a new head of state faltered. ${ }^{3}$ During this quest for an appropriate new Lord of the Netherlands, "independence", whether a conscious aim or a necessity that

2 For the development of the Dutch Revolt and the political thought connected with it cf., inter alia, Parker G., The Dutch Revolt (London:1977); idem, "Success and failure during the first century of the Reformation", Past and present 136 (1992) 43-82; Elias B.G.J., De Tachtigjarige Oorlog (Haarlem: 1977); Lem A. van der, De Opstand in de Nederlanden 1568-1648: De Tachtigjarige Oorlog in woord en beeld (Nijmegen: 2014); Gelderen M. van, The political thought of the Dutch Revolt 1555-1590 (Cambridge: 1992); idem (ed.), The Dutch Revolt. Cambridge Texts in the history of political thought (Cambridge: 1993); and furthermore Baalbergen, J., Van Opstand tot onafhankelijkheid. De Unie van Utrecht en het ontstaan van een zelfstandige staat 1559-1609 (,s-Gravenhage: 1979); Bremmer R.H., Reformatie en rebellie. Willem van Oranje, de calvinisten en het recht van opstand. Tien onstuimige jaren: 1572-1581 (Franeker: 1984); Demandt K.E., "Wilhelm I. von Nassau, Prinz von Oranien, und die Bedeutung und Stellung des Abfalles der Niederlande im Rahmen der europäischen Revolutionen", Nassauische Annalen 80 (1969) 121-136; Deursen A.Th. van, "De Republiek der Zeven Verenigde Nederlanden (1588-1780)", in idem, De hartslag van het leven. Studies over de Republiek der Verenigde Nederlanden (Amsterdam: 1996) 13-87; Duke A.C., "From king and country to king or country? Loyalty and treason in the revolt of the Netherlands", in Transactions of the Royal Historical Society,

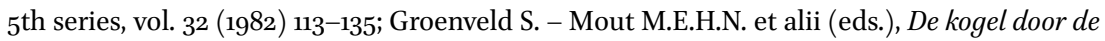
kerk? en De bruid in de schuit, 2 vols. (Zutphen: 1991 ${ }^{3}$ ); iidem - Leeuwenberg H.Ph. (eds.), De Tachtigjarige Oorlog: opstand en consolidatie in de Nederlanden (ca. 1560-1650) (Zutphen: 2008); Groenveld S., Unie - Bestand - Vrede. Drie fundamentele wetten van de Republiek der Verenigde Nederlanden (Hilversum: 2009); Israel J.I., The Dutch Republic. Its Rise, Greatness, and Fall 1477-1806 (Oxford: 1995); idem, Conflicts of Empires. Spain, the Low Countries and the Struggle for World Supremacy, 1585-1713 (London - Rio Grande: 1997); Mout, M.E.H.N., "Van arm vaderland tot eendrachtige republiek. De rol van politieke theorieën in de Nederlandse Opstand", Bijdragen en Mededelingen betreffende de Geschiedenis der Nederlanden 101 (1986) 345-365; eadem, "Reformation, revolt and civil wars: the historiographic traditions of France and the Netherlands", in Benedict Ph. et alii (eds.), Reformation, revolt and civil war in France and the Netherlands 1555-1585 (Amsterdam: 1999) 23-34; Arnade P., Beggars, iconoclasts, and civic patriots: the political culture of the Dutch Revolt (Ithaca, N.Y.: 2008); Saage R., Herrschaft, Toleranz, Widerstand. Studien zur politischen Theorie der niederländischen und der englischen Revolution (Frankfurt am Main: 1981).

3 Cf., inter alia, Koenigsberger H.G., Monarchies, States Generals and parliaments: the Netherlands in the fifteenth and sixteenth centuries (Cambridge: 2001); Dunthorne H., Britain and the Dutch revolt, 1560-1700 (Cambridge: 2013); Oosterhoff, F.G., Leicester and the Netherlands $1586-1587$ (Utrecht: 1988). 
had arisen, remained a fait accompli. From the 1590s onwards, an increasing proportion of society in the Northern Netherlands was convinced that it was unachieavable, and ultimately not even desirable, to return to a monarchist system under a foreign prince. By the time of the Twelve Years' Truce, ${ }^{4}$ such a model had almost completely been discounted. Ultimately, the aim was to found an independent state in some form or other. We see the enunciation of this aim most particularly in the Netherlands' key province, Holland. In this regard, the Counts of Holland took on new significance: they now came to be back-projected as the leaders of a previous 'independent' state, one which was now being restored. In this way, they could be invoked as a means of shaping and legitimising the identity of the new independent Holland. ${ }^{5}$

\section{The Counts as Opponents to the Revolt: Vosmeer's and Galle's Principes Hollandiae (1578)}

The first portrait series of the Counts of Holland appeared in 1578, brought out by the renowned publisher Christopher Plantin at Antwerp. The artist was engraver Philip Galle (1537-1612) of Haarlem [Fig. 10.1], and the appended verses were by lawyer Michiel Cornelis Vosmeer (ca. 1550-1616). ${ }^{6}$ The political aim of this publication is evident already on its title page [Fig. 10.2], which depicts a personification of the Province of Holland as a young woman holding a coat of arms with a lion, the heraldic symbol of the Counts of Holland. In the year in

4 Cf., inter alia, Groenveld S., Het Twaalfjarig Bestand 1609-1621. De jongelingsjaren van de Republiek der Verenigde Nederlanden (Hilversum: 2009); Lem A. van der, "Een voordelige vrede: het Twaalfjarig Bestand, 1609-1621", Geschiedenis magazine 44.3 (2009) 14-19.

5 For the question of the new Dutch identity cf., inter alia, Duke A., "The elusive Netherlands. The question of national identity in the early modern Low Countries on the eve of the Revolt", Bijdragen en Mededelingen betreffende de Geschiedenis der Nederlanden 119 (2004) 10-38; Groenveld S., "Natie en nationaal gevoel in de zestiende-eeuwse Nederlanden", Nederlands Archievenblad 84 (1980) 371-387; idem, "Nation und 'patria': Begriff und Wirklichkeit des kollektiven Bewusstseins im Achtzigjährigen Krieg”, in: idem - Lademacher H. (eds.), Krieg und Kultur: die Rezeption von Krieg und Frieden in der Niederländischen Republik und im Deutschen Reich, 1568-1648 (1998) 77-109, and 524-534; Groenveld S., "Natie' en 'patria' bij zestiende-eeuwse Nederlanders", in: Sas N.C.F. van (ed.), Vaderland (Amsterdam: 1999) 55-81; Kossmann E.H., Een tuchteloos probleem. De natie in de Nederlanden (Leuven: 1994); Pollmann J., "No man's land: reinventing Netherlandish identities, $1585^{-1621}$ ", in Stein R. Pollmann J. (eds.), Networks, regions and nations: shaping identities in the Low Countries, 13001650 (Leiden: 2009) 241-262; Pollmann J, Catholic identity and the Revolt of the Netherlands 1520-1635 (Oxford: 2011).

6 Vosmeer Michiel, Principes Hollandiae en Zelandiae, domini Frisiae [...]. Cum genuinis ipsorum iconibus [...] (Antwerp, Christopher Plantin: 1578). 


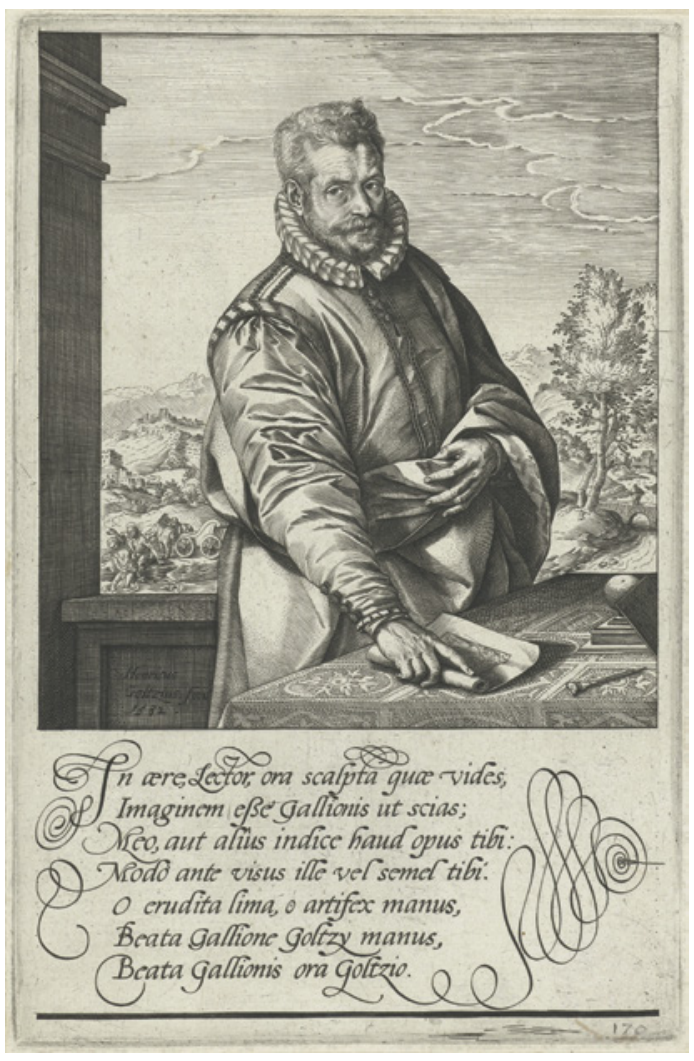

FIGURE 10.1

Hendrick Goltzius, Portrait of the engraver Philip Galle (1582). Engraving $22.3 \times 14.5 \mathrm{~cm}$ IMAGE (C) RIJKSMUSEUM, AMSTERDAM

which this publication appeared, the Revolt was in full flow in the Province of Holland. Following the battlefield successes of 1574 and 1576, the Province was no longer prepared to submit to Philip II by this stage. However, we see something quite different from militarism on the title page: Lady Holland holds a palm branch in her hand, denoting that the Province acknowledges the King of Spain as her rightful Count and wishes him victory.

The author of the texts in the series, Michiel Vosmeer, makes no secret of his political loyalties: he devotes the work to Master Sir Arnoud Sasbout (d. 1583), Lord of Spalant, who had been appointed in 1575 chairman of Philip's Privy Council in Brussels. ${ }^{7}$ In the northern provinces, the Privy Council was feared

7 Ibidem, fol. A2r. However, circa 1576 he seemed to have moved to The Hague, which is not mentioned by Vosmeer. Nevertheless, Sasbout's salary as counsellor to Philip was still being paid in 1579. For, Sasbout cf. Baelde M., De collaterale raden onder Karel V en Filips II (15311578). Bijdrage tot de geschiedenis van de centrale instellingen in de zestiende eeuw (Brussels: 1965) 304, and Nieuw Nederlands Biografisch Woordenboek, vol. II, cols. 1264-1265. 


\section{P R I N C I P E S \\ HOLLANDIAE \\ ET Z Z L A N I AE,}

DOMINI FRISIA:

Auctore Michaële Vofmero.

Cv M genuinis ipformm iconibus, ì Theodorico Aquitanie ad Iacobam Bawaries diser forum quondam pilfor wm opera, ad viuum fedulo depiCtis : Nunc autem primim ex vetuffi 3 mis parictibus, in Carmelo obfe fJe vrbis Harlemi, per prefidiarios direpto, indufris Guilielmi Thybauti repertis, ac fincerè vnà cum religuorum Princtpom figuris, ad instar probati Stmorum exemolarum delineatis.

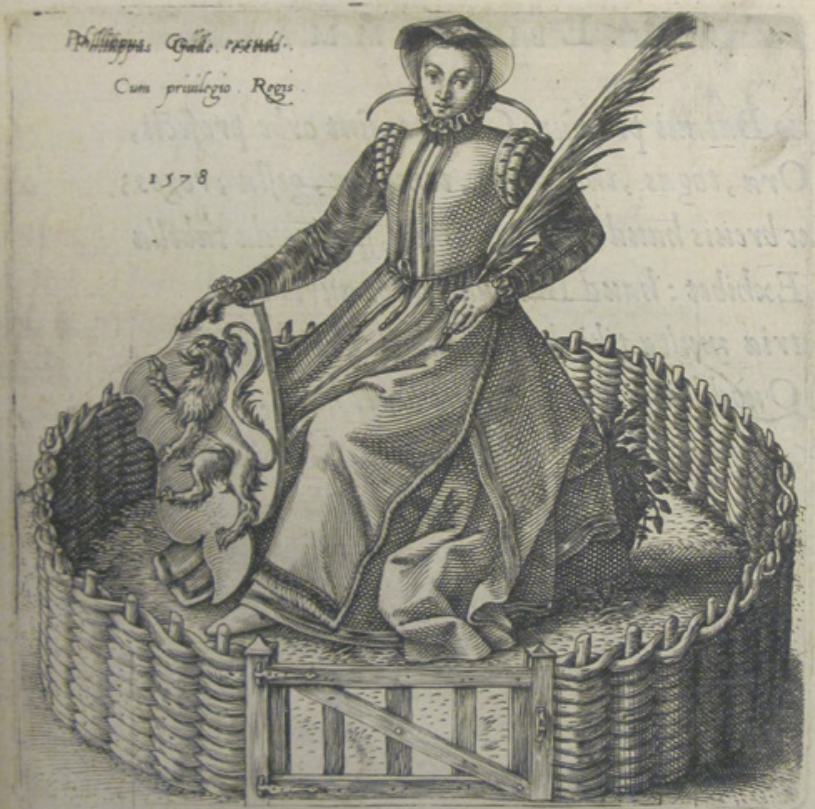

$$
\begin{gathered}
\text { A N T V E R P I } \\
\text { Excudebat Chriftophorus Plantinus } \\
\text { Philippo Gallxo. } \\
\text { M. D. Lxxvirx. }
\end{gathered}
$$

FIG URE 10.2 Michiel Vosmeer, Principes Hollandiae et Zelandiae, domini Frisiae (Antwerp, Christopher Plantin: 1578), title page

IMAGE (C) UTRECHT UNIVERSITY LIBRARY 
and loathed as much as Philip himself, because it was held responsible for the injustices and violence afflicting the population. Sasbout was one of the most implacable opponents of both the Dutch Revolt and the Reformation. For instance, in 1565, he went, Saul-like, in person to Leiden to haul Calvinists off to jail. It is of major political significance that Vosmeer dedicated the work to none other than the Chairman of Philip II's Privy Council and that he even praises him as its 'most vigilant president'. In his dedicatory poem, Vosmeer deplores the present political unrest, which he characterises as a civil war. Complaining about how 'the loyalty of those who are not content with any leader at all has evaporated', he expresses the hope that better times may come again. Remarkably, the political intent of Vosmeer's work has recently been misunderstood. ${ }^{8}$

Given his politics, it will not be surprising that Vosmeer acknowledges Philip as Count of Holland and actual political authority in the province. Philip is presented as the thirty-sixth legitimate count [Fig. 10.3]. In his dedicatory poem, Vosmeer emphasises the legitimacy and continuity of Philip's reign. In the associated epigram, Philip is made to say of himself: 'Now I, Philip, in a line of direct descent, hold this sceptre, passed on by countless forefathers [...].$^{9}$ In addition, Philip is fêted as the great victor over the Turks. ${ }^{10}$ This is an allusion to the glorious sea-battle of Lepanto (1571), whose commander had been Philip's half-brother, Don Juan of Austria. Philips is presented glorying in his role as saviour of European Christendom. The engraved image contains both Philip's impressive coat of arms and the chain of the Order of the Golden Fleece, in minute detail, so that none can doubt his legitimacy.

8 Acuriousinterpretation of Vosmeer and Galle's series is that of Miriam Volmert(VolmertM., Grenzzeichen und Erinnerungsräume. Holländische Identität in Landschaftsbildern des 15.-17. Jahrhunderts [Berlin - New York: 2013] 75): she asserts that the publication was intended to express the rebels' new political stance; in place of the old counts, it was now the Seven United Provinces which were claiming the right to rule in defiance of the sovereign Philip II. It will be evident that this cannot be a correct understanding, even discounting what Vosmeer himself says. After all, the book was dedicated to none other than the chairman of Philip's privy council and was published at Antwerp 'with royal privilege' ('cum privilegio regis') - i.e. by permission of Philip II himself. A book supportive of the rebels would never have obtained such publishing privileges. Volmert erroneously supposes that the lion coat of arms was new and was intended to represent the new-born state of Holland. In fact, the lion is nothing more than the old heraldic symbol of the Counts of Holland.

9 Vosmeer, Principes Hollandiae, p. 78: 'Haec ego (continua veniens de stirpite) Philippus / Sceptra gero, innumeris tradita nuper avis'.

10 Ibidem: 'Auspice me $[\ldots]$ / Turcorum [...] phanlanx funditus acta ruit'. 


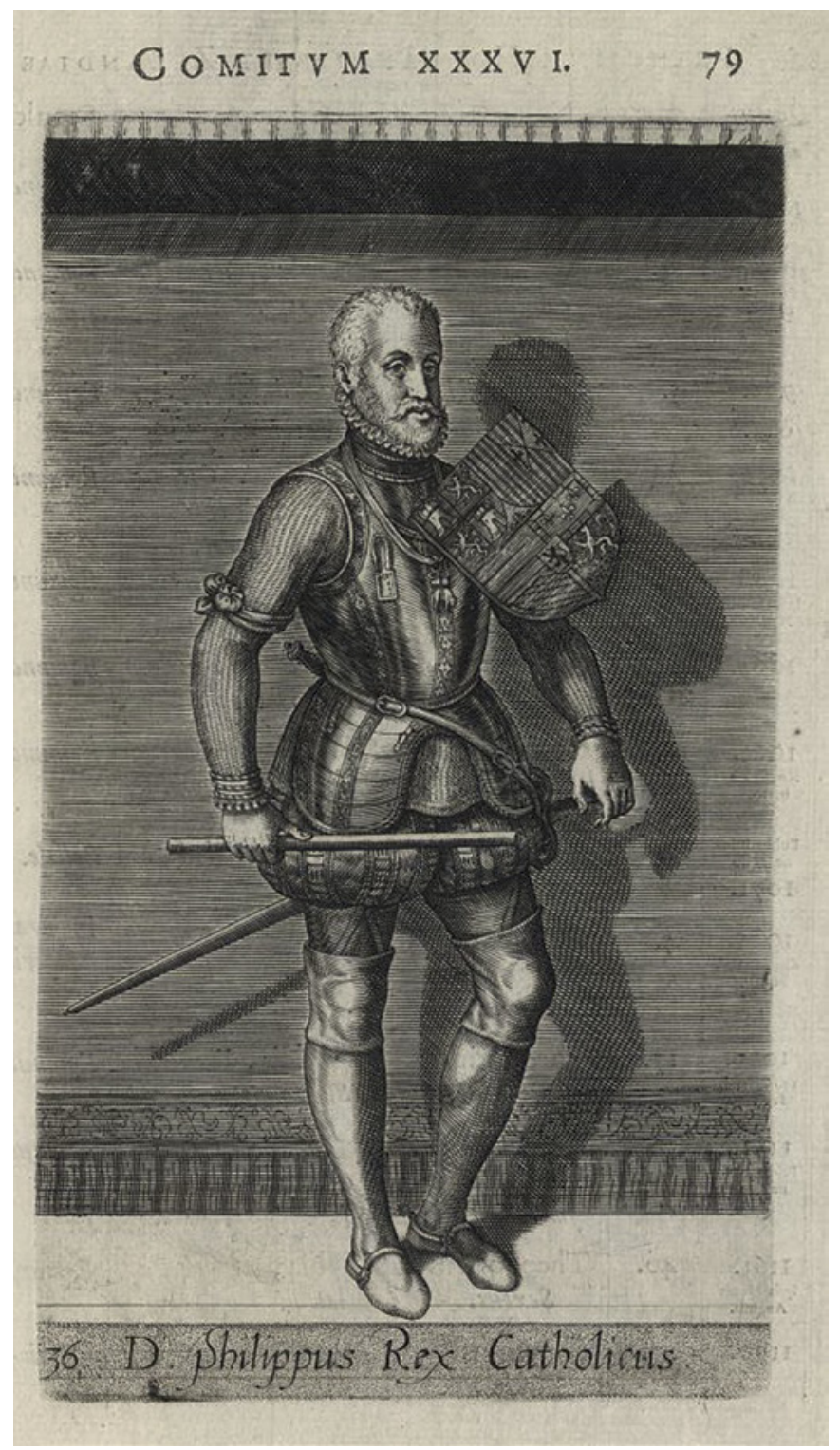

FIGURE 10.3 Philip II of Spain as the 36 th Count of Holland. Engraving by Philip Galle, taken from: Michiel Vosmeer, Principes Hollandiae et Zelandiae, domini Frisiae

(Antwerp, Christopher Plantin: 1578) 79

IMAGE (C) UTRECHT UNIVERSITY LIBRARY 
The formal presentation and layout of the printed series was intended to portray the counts as imposingly as possible. This was one of the reasons why the format chosen for these portraits was the most solemn of all: the state portrait, presenting the full body, in Early Modern times usually the preserve of princes. Each of the 36 portraits takes up a whole page (the right-hand page) and depicts the whole body of the count in question, who is presented standing and posing in full armour. The left-hand page in each case contains Vosmeer's associated poem, a Latin epigram recounting the count's key genealogical details and feats.

\section{Vosmeer's Counts of Holland as Trojans}

Even the first portrait in the series is so conceived as to depict the Counts of Holland with maximum legitimacy. We find 'Dirk of Aquitania' ('Theodoricus Aquitaniae') presented as the first Count of Holland [Fig. 10.4], whom Vosmeer specifies as 'the younger son of the Duke of Aquitania, Sigisbertus..1 The accompanying poem for his portrait informs us that this Dirk is counted among 'the Trojan forebears'.12 This Dirk is thus no indigenous nobleman (as the historical Dirk and his real father, Gerulf, actually were), ${ }^{13}$ but an exotic foreigner from distant Aquitania (in south-western France), with Trojan blood coursing through his veins. In line with this approach, Galle's portrait depicts Dirk as a Trojan prince, in the way oriental rulers were imagined: wearing as headgear a fantastical turban adorned with a bunch of feathers, and shrouded in a long royal robe lined with ermine fur. His shield depicts the lion: the shared heraldic symbol of both the Counts of Holland and the Troyan royal family. Several counts in the series are similarly depicted, such as William I [Fig. 10.5].

Vosmeer embroiders the Trojan origin of the counts in his introductory poem to the reader: ${ }^{14}$ we are told that Dirk's father was one Sigisbertus, a scion of the royal house 'with the lily' (an allusion to the French royal family). ${ }^{15}$ According to the legend as related, the founder of the Merovingian dynasty,

\footnotetext{
11 Ibidem, fol. A2r: 'Didericus Aquitaniae, Sigiberti ducis Aquitaniae filius minor'.

12 Ibidem, p. 8: 'Trojae dinumerandus avis'.

13 For Dirk I and his father Gerulf cf. de Boer - Cordfunke, Graven van Holland 13-17. Dirk I was regarded as the first Count of Holland even as early as in the chronicle of Melis Stoke. De Boer - Cordfunke (14) emphasise that, according to the documents, the first Count of Holland was actually a certain 'Gerulf' who is mentioned in a document of 889 (kept at Egmond Abbey). In this view, Dirk was the second Count of Holland.

14 Vosmeer, Principes Hollandiae, p. 5-6.

15 Ibidem, p. 6: ‘[...] genus alto a sanguine regum, / Patre Sigisberto [...]'.
} 


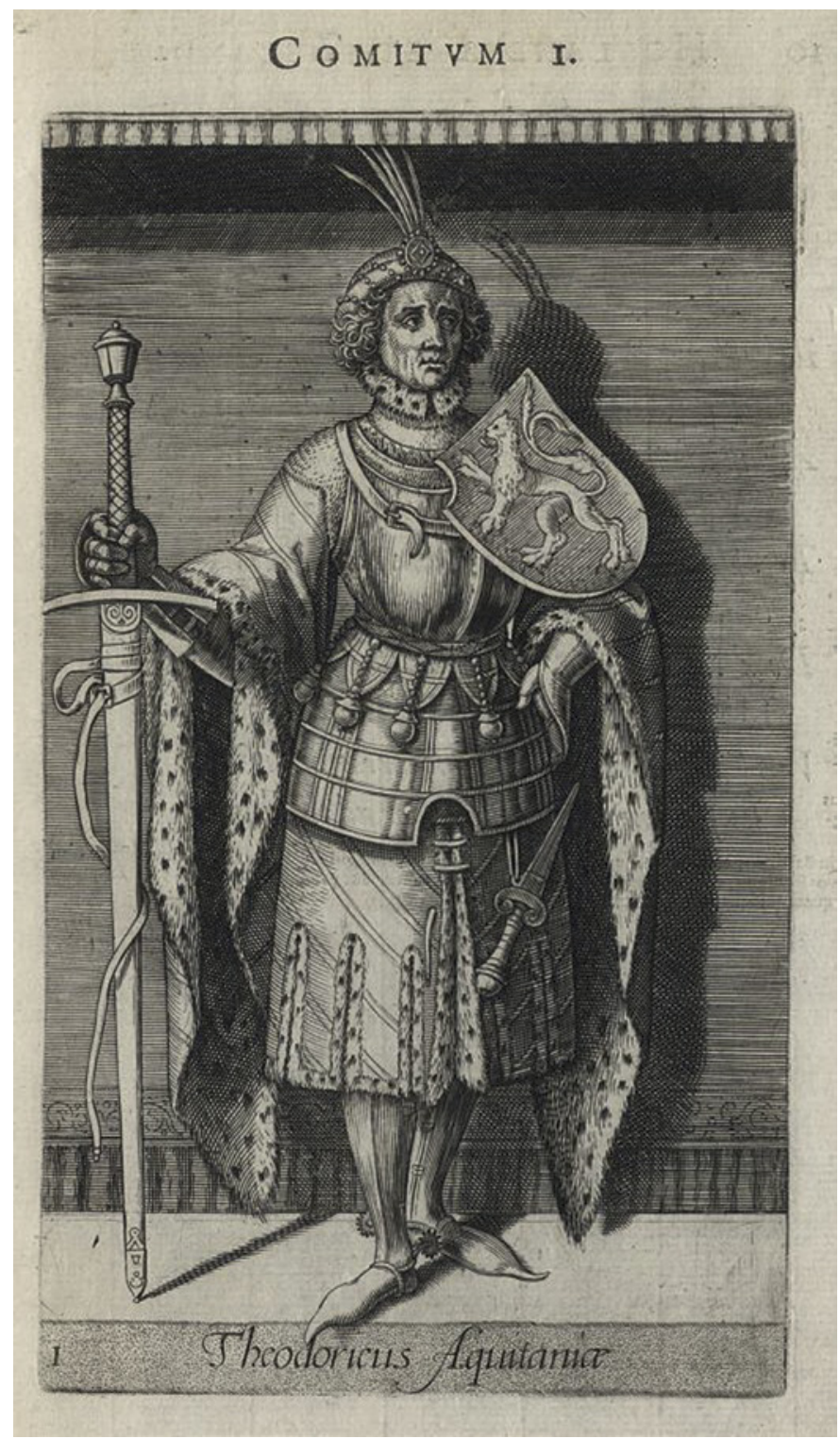

FIGURE 10.4 Dirk I ("Theodoricus [ab] Aquitania”), the First Count of Holland. Engraving by Philip Galle, taken from: Michiel Vosmeer, Principes Hollandiae et Zelandiae, domini Frisiae (Antwerp, Christopher Plantin: 1578) 3 IMAGE (C) UTRECHT UNIVERSITY LIBRARY 


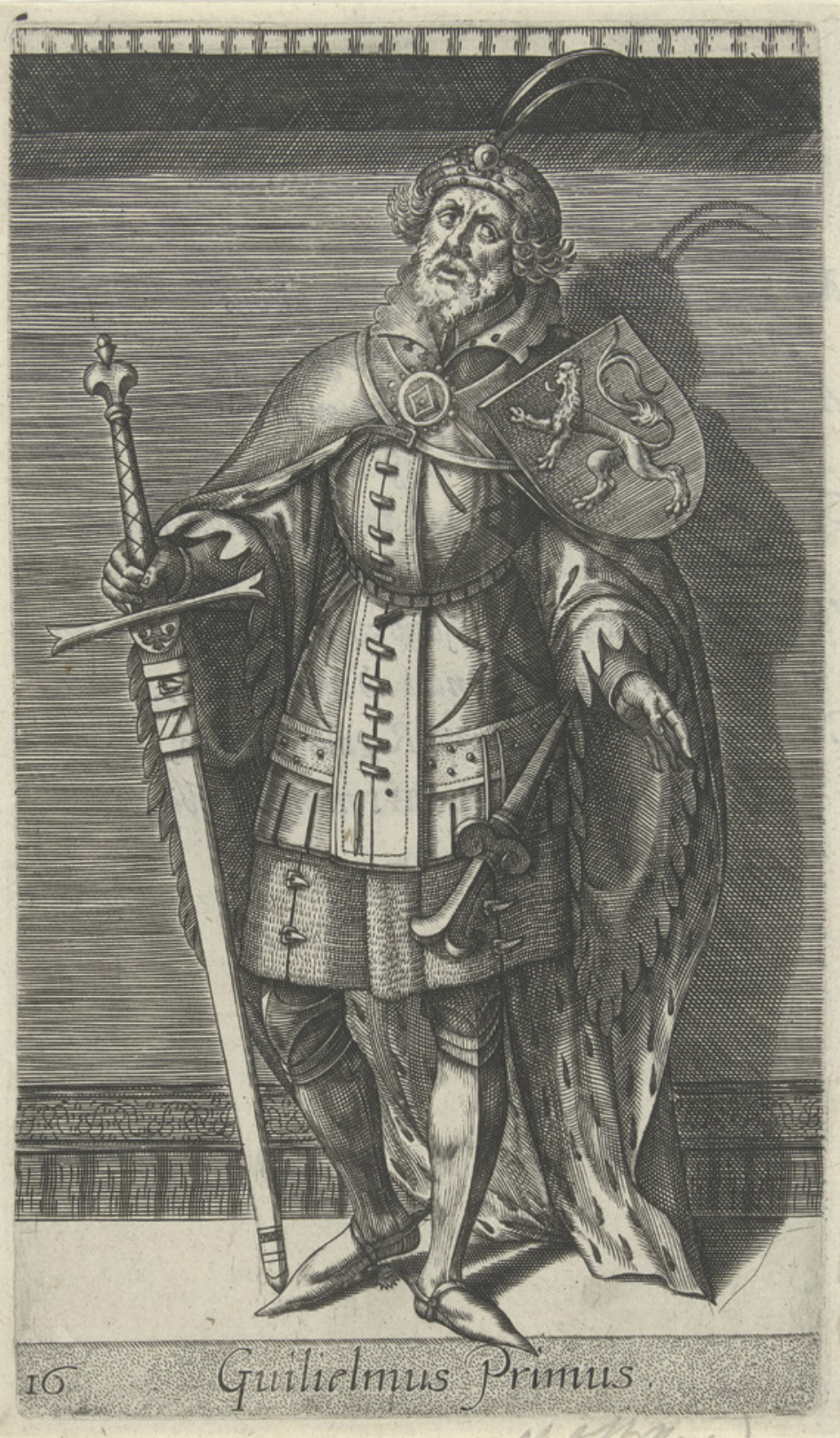

FIGURE 10.5 William I, the 16th Count of Holland. Engraving by Philip Galle, taken from: Michiel Vosmeer, Principes Hollandiae et Zelandiae, domini Frisiae (Antwerp, Christopher Plantin: 1578) 35 IMAGE (@) UTRECHT UNIVERSITY LIBRARY 
Clovis I, received his lily crest from heaven at the hands of an angel, subsequent to his having obtained his greatest victory following his christening (496). Both Clovis and his Merovingians and the Carolingian dynasty traced their lineages back to Hector of Troy, Priam's son. In the poem, Dirk is accorded 'the lilies', thereby associating him with just about the most ancient forefathers that anyone could imagine, namely the Trojan princes. Nevertheless, Dirk's coat of arms is actually older and more original than that of Merovingians, the first French kingly line: rather than the lilies, he bears the lion in his coat of arms, reputedly the heraldic symbol of the Trojan royal family. 'Theodoricus of Aquitania', the founder of Holland, echoes Aeneas of Troy, the founder of Rome (through Alba Longa), and Antenor of Troy, supposedly the founder of Padua. Vosmeer's verses refer to the discourse of the heroic poem (epos), and particularly to Virgil's Aeneid. The transfer of power to Dirk I is presented as a 'decision of the gods' ('Sic placitum superis'). ${ }^{16}$ This is a quotation from the Aeneid, taken from Jupiter's speech in which the chief god predicts that Aeneas will ultimately found the Roman Empire, the realm of 'the toga-wearing people, the lords of the world. ${ }^{17}$ The Trojan origin of Dirk I of Holland is thus portrayed as a parallel to the genealogical ambitions of the Habsburgs, who claimed to trace their own descent from the Trojans and indeed from Aeneas himself.

On top of this, Vosmeer inflates Dirk's I impressive-enough noble ancestry by adding that his consort was also of Trojan origin: one 'Gena' or 'Gunna', daughter of Pepin Carloman or Pepin of Italy (also Pippin Carloman or Peppino, 773-810), the second son of Charlemagne, who was made King of Italy at the age of only eight years (r. 781-810) when his father conquered the Lombards (810). ${ }^{18}$ Because the Carolingians likewise traced their family tree back to King Priam of Troy, a marriage with a granddaughter of Charlemagne meant yet another injection of Trojan blood into the counts' veins. Vosmeer was not the inventor of this fraudulent implant in the family tree, but he nevertheless took it over without a critical note. In reality, Pepin of Italy had five daughters born to him between 798 and 809, Adelheid (Adelaida), Atala (Adele), Gundrada, Bertha, and Theodrada (Tetrada). Atala (Adele), Gundrada, and Bertha all died in childhood, namely before Charlemagne's death in 814. Pepin's eldest daughter Adelheid (b. 798 [or 799], d. ca. 825), married Lambert I Count of

\footnotetext{
16 Ibidem: 'Sic placitum superis, sic magnus Rector Olympi / Annuit' - 'So it was decided by the gods, so it was ratified by the great ruler of the Olympus'.

17 Virgil, Aeneid I, 282-283.

18 Cf. the marginal note added by Vosmeer, Principes Hollandiae, p. 8: 'Uxor Theodorici Gena, seu Gunna, filia Pippini minoris, regis Italiae' - 'The consort of Dirk [was] Gena or Gunna, a daughter of Pepin the Younger, the King of Italy'. In Vosmeer's poem, line 8: 'uxor regia Gena fuit' - 'his wife was Gena the decendant of a king'.
} 
Nantes (d. 836), and died before her husband (ca. 825); Pepin's younger daughter Theotrada married Lambert II Count of Nantes (d. 851), and died in 939. She bore the him three children, among them Lambert, later the III Count of Nantes. Thus, there was no daughter of Pepin of Italy Dirk I could have married. It is clear in itself that this genealogical construction must be mere fake, no matter whether one departs from the wrong early date of Dirk's I reign (863), as Vosmeer does, or from the historical date confirmed by documents (922). ${ }^{19}$

Equally woundrous is Vosmeer's claim that Dirk's father was one 'Sigisbertus' (Sigibert or Siegbert), 'Duke of Aquitania.' ${ }^{20}$ The origins of this supposed Sigisbert are a mystery. For the period in which Dirk I was supposed to have taken control over Holland (863) the list of Dukes of Aquitania features no-one of the name Sigisbert or Siegbert. But in Merovingian times there had been three kings of Austrasia with that name: Siegbert I (r. $5^{61-575)}$, the fifth son of king Chlothar I (d. 561); Siegbert II (b. 602, d. 613) an illegitimate son of Theuderic II who for a short period in 613 became king of Austrasia (as an infant); and finally Siegbert III (634-ca. 660), a son of Dagobert I. However, none of these Merovingian Siegberts can possibly have been Dirk's father. Siegbert II died aged eleven, without issue. Neither Siegbert I nor Siegbert III had a son called Dirk (or Theodoricus). ${ }^{21}$ None of the three chronologically fits the year given by Vosmeer as the accession of Dirk I to the County of Holland, 863. There are fully three centuries between Siegbert I's reign and the year 863 !

19 Cf. de Boer - Cordfunke, Graven van Holland 13.

20 Vosmeer, Principes Hollandiae, fol. A2r: 'Didericus Aquitaniae, Sigiberti ducis Aquitaniae filius minor'. For the origins of the connection with Aquitania, see:AnrooijW.van, "Aquitanië en de herkomst van de Hollandse graven, een 14de-eeuwse traditie", in Boer D.E.H. de Cordfunke E.H.P. - Hugenholtz F.W.N. (eds.), Holland in wording. De ontstaansgeschiedenis van het graafschap Holland tot het begin van de vijftiende eeuw, Muiderberg symposia 5 (Hilversum: 1991) 125-142: Peeters J., "Die internationalen Beziehungen des ersten Grafen von Holland. Sagenhafte Elemente in der niederländischen Geschichtsschreibung des Mittelalters", in Gemert G. van - Ester H. (eds.), Grenzgänge. Literatur und Kultur im Kontext [...] (Amsterdam: 1990) 3-32, and recently, Keesman W., De eindeloze stad. Troje en Trojaanse oorsprongsmythen in (laat)middeleeuwse en vroegmoderne Nederlanden (Hilversum: 2017), esp. 543-550, and 555-557. According to Keesman, the genealogical construction of the Trojan origins of the Counts of Holland did not yet exist in the 14th

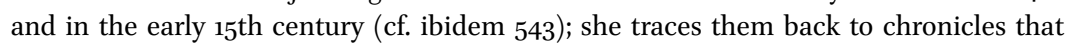
were composed in the second half of the 15th century, for example to Jan Gerbrandzoon van Leiden's Brederode chronical or Dirk Frankenzoon Pauw's chronical (esp. 544-545). For the historical genealogy: Dek A.W.E., Genealogie der graven van Holland (Zaltbommel: 1969).

21 Siegbert I had a son called Childebert who also became king of Austrasia (570-595). 
If one departs from the historically documented date of Dirk's accession, 922, the genealogical construction becomes even more wondrous. ${ }^{22}$

The Counts of Holland were simply implanted into the family tree of the Dukes of Aquitania for felicitous effect. Vosmeer did not invent the fake, but he was following a tradition, which was among the $15^{\text {th }}$ century chroniclers such as Jan van Leiden very popular, ${ }^{23}$ and he was not particularly accurate or critical with his historical sources either. He was largely concerned with magnifying the Counts of Holland by claiming a descent that was as much timehonoured, and hence as impressive, as possible.

Arnout I (or Arnulf I), the third Count of Holland, brought according to Vosmeer an additional injection of Trojan blood into the counts' veins. In the poem we are told that Arnout I was married to one 'Lutcharis', the daughter of a 'Trojan emperor' ('Dardanus induperator'). ${ }^{24}$ The Latin noun induperator is an archaic form of imperator, the title from the ist century BC on used to denote the Roman emperors. This Trojan princess is said to have born Arnout children including a son 'Zyphridus', who went on, we are told, to found the lineage of the Brederodes. ${ }^{25}$ Dardanius is a synonym for Troianus much used

22 Keesman, De eindeloze stad 544, gives the puzzling information that Dirk I, Count of Holland, was an offspring of the 'Merovingian Chilperik, hertog of Aquitanië en broer van koning Dagobert II [...]. Chilperiks nakomelingen, de laatsten uit het Trojaanse koningshuis en de eigenlijke rechthebbers op de troon, bleven na Pippins opvolging heersen in Aquitanië'. However, Dagobert's II brother was not a 'Chilperik' (or Chilperic), but Childebert (i.e. Childebert the Adopted) who was 656-657 (or 662) king of Austrasia (Aquitania being the most important part of Austrasia). Moreover, Chilperich was surely not a Merovingian, but a Karolingian (Pippinide), being the true son of the Frankian Hausmeier Grimoald (ca. 615-657 or 662). Childebert the Adopted was killed very soon by Clovis II. Childebert cannot possibly have been a forbear of Dirk I, because he died without offspring. The same goes for another Chilperic, who only very briefly (in the year 632) occupied the throne of Aquitania, as infant child of Charibert II, Duke of Aquitania who died at the young age of 18 . This Chilperic was killed shortly after he came to power by orders of king Dagobert I. He was a Merovingian, but not the brother of a 'king Dagobert II'.

23 Cf. Anrooij, "Aquitanië en de herkomst van de Hollandse graven"; Keesman, De eindeloze stad esp. 543-545. Keesman says that Dirk Pauw's chronical is the oldest known source of the Trojan origin of the Counts of Holland (ibidem 545, note 220); according to van Anrooij the myth existed already in the 14th century. De Boer - Cordfunke, Graven van Holland 13, call the Trojan anchestry of the Counts in the 15th century a 'successtory'.

24 Vosmeer, Principes Hollandiae, p. 12: 'Sic Arnoldus eram, quem Dardanus induperator / Lutcharidis natae praetulit esse virum' - 'Such was I, Arnout, whom the Trojan emperor chose as husband for his daughter Lutcharis' (emphasis mine).

25 For the genealogical construction supposedly tracing the Brederodes back to Arnout I, cf. Lulofs M., "Die van Brero heeft men eens gezien. De 'Brederode-kroniek' van Jan van Leyden", in Ebels-Hoving B. - Santing C.G. - Tilmans C.P.H.M. (eds.), Genoechelijcke ende 
by Virgil in his Aeneid, referring to Dardanus the founder of Troy. ${ }^{26}$ Frequently, the Roman poet called the Trojans Dardanidae ${ }^{27}$ or Dardanii, Troja Dardania, and the military leader of the Trojans (i.e., Aeneas), Dardanus. ${ }^{28}$ Dardanus as an adjectivum is more rare, but it nevertheless occurs, e.g., in the phrase 'Dardana pubes.' ${ }^{29}$ Vosmeer is, however, transferring this adjective to the later inhabitants of the Dardanelles, i.e., to the Byzantines. From a marginal commentary note it becomes clear that he identifies the 'Dardanus induperator' with the Byzantine Emperor: 'Lutcharis, daughter of Theophanes, the emperor of Byzantia, was given in marriage to Arnout. The Brederodes descend from Zyphridus. ${ }^{30}$

These assertions are remarkable. There was never a Byzantine emperor named Theophanes, just as history knows of no Byzantine princess called Lutcharis. These are historical fantasies, consciously created - and perhaps also arising from a kind of "creative error": although there was no Byzantine emperor with the name 'Theophanes', there were Byzantine princesses and empresses named Theophanou (also 'Theophano') such as Theophanou of Athens (d. after 811), the daughter of the Byzantine Emperor Nikephorus I and the wife of Emperor Stauriakos (after 778-812), Theophanou (d. 893), the consort of Byzantine Emperor Leo the Wise (866-912), Theophanou of Sparta (941-978), the wife of the Emperors Romanos II and Nikephoros II Phokas, and especially Theophanou (ca. 959/60-991), the niece (or granddaughter) of the Byzantine Emperor Johannes Tzimiskes (b. 925; r. 969-976), who was given in marriage to Otto II in 972, and who was crowned together with Otto Holy Roman Emperor and Empress in 980. This Theophanou was an important figure: after Otto II died unexpectedly in 983 (from malaria) she actually ruled the Holy Roman Empire from 983 to 994 as regent for her immature son Otto (later Otto III). ${ }^{31}$ Because Vosmeer does not mention the name 'Theophanes' in the

lustige historiën. Laatmiddeleeuwse geschiedschrijving in Nederland (Hilversum: 1987) 79-99.

26 Cf. e.g. Aeneis II, 618; IV, 662; V, 119; VI, 57; VII, 219; XI, 287. For Dardanius cf. e.g. Aeneis I, 494; 602; 617; II, 582; III, 596; IV, 163; 224; 626; 640; 647; 658; V, 30; 711; VI, 169; X, 92; X, 133; $\mathrm{X}, 603$ etc. Dardanus the founder of Troy is mentioned e.g. in Aeneis III, 167; III, 503; IV, $365 ; \mathrm{VI}, 650$.

27 Cf. ibidem I, 560; II, 59; 72; 242; 445 etc.

28 Cf. ibidem, e.g. IV, 662; XI, 287.

29 Cf. ibidem, II, 618 'Dardana arma'; IV, 662 'Dardana pubes'; V, 119 'Dardana tela'; XI, 287 'Dardana pubes'.

30 Vosmeer, Principes Hollandiae, p. 12: 'Lutcharis, Theophanis Byzantiae Imperatoris filia, Arnoldo nupsit'.

31 For Theophanou cf. Davids A. (ed.), The Empress Theophanu. Byzantium and the West at the turn of the first millennium (Cambridge U.P.: 1995); Wolf G. (ed.), Kaiserin Theophanu. 
poem, but only in an explanatory commentary note, he was probably not the inventor of this family tree construction, but used an already exisiting tradition to which he refers in his comment. And indeed, he could build on such a tradition, as we will see. ${ }^{32}$ In this tradition, the father of Arnout's wife was called 'Theophanus', which is the Latin form of a (supposed and construed) Greek name 'Theophanos'. 'Theophanou' could have been regarded as a patronymic form (father's name), and it may well be that the familiy tree construction was ultimatively build on a grammatical derivation: if there is a daughter called 'Theophanou', there must have been a father with that name. If the daughter was an Empress, why could not her father have been an Emperor as well?

However, it is fair to notice that Vosmeer actually does not mention an/the Empress Theophanou. He confines himself to the construed emperor's name. Nevertheless, in the way in which Vosmeer rendered his name he proofs to be a philologist. In his source Vosmeer found the name as 'Theophanus', obviously the Latin form for the Greek 'Theophanos'. Unfortunately, 'Theophanos' was not a current Greek name, and Vosmeer was obviously aware of that fact. The correct masculin form is 'Theophanes'. In Byzantine history and literature, this name occurs quite frequently, and there are numerous examples of well-known bearers of it, e.g. the historiographer Theophanes of Byzantium (6th century), the monk and chronicler Theophanes the Confessor (ca. 758ca. 817), the monk and hymnographer Theophanes the Branded (775-845), Theophanes the chief minister of Emperor Romanos Lekapenos (1oth century), Theophanes Nonnus, a Byzantine physician who authored a medical compendium dedicated to Emperor Constantine VII Porphyrogenitus (1oth century), etc. Thus, Vosmeer corrected the grammatical form of the name of the Byzantine Emperor that actually did not exist, into Theophanes.

The name 'Lutcharis' likewise seems to be based on a grammatical construction made up by Vosmeer, representing a combination of the Dutch word lout ('pure') and the Greek word Xápı ('womanly attractiveness, charm'), thus meaning 'pure charm'. This philological construction possibly reflects the real name of Arnout's wife, Liutgarde or Luijtgaert. ${ }^{33}$ Lutgardis or Liutgarde, however, was not the daughter of a Byzantine Emperor, but of Siegfried of Luxembourg, Count of the Ardennes and Luxembourg (ca. 922-998), the founder of the castle of 'Lucilinburhuc' (Luxembourg), and his wife Hedwig of

Prinzessin aus der Fremde - des Westreichs große Kaiserin (Cologne: 1991); von Euw A. Schreiner P. (eds.), Kaiserin Theophanu. Begegnung des Ostens und Westens um die Wende des ersten Jahrtausends. Gedenkschrift zum 10oo. Todesjahr der Kaiserin (Cologne: 1991), 2 vols.

32 See below, the next section.

33 For Lutgardis see de Boer - Cordfunke, Graven van Holland 23-24. 
Nordgau. Lutgardis was born in 955 and grew up in the castle 'Lucilinburhuc'. Her sisters were Cunigunda, Eva, and Ermentruda, her brothers Henry (later Henry I Luxembourg), Siegfried, Dietrich II (later bishop of Metz), Adalberon, and Gislebert. After Arnout's death, she ruled Holland during the minority of her son Dirk (993-1005).

Fanciful philology seems, too, to be responsible for the fantastic name of Lutgardis's second son, 'Zyphridus', ${ }^{44}$ which is obviously intended to suggest Greek origin. 'Zyphridus', which is of course not an attested Greek word, is vaguely redolent of 'Zephyros', the Greek name for the west wind. However, this 'Zyphridus' actually covers the standard Germanic 'Siegfried' (or Sicco), the real name of Lutgardis' and Arnout's younger son (985-1030). It could be that Vosmeer was inspired for the construction of this fantasy name by the captions of the Haarlem panels, too. There, his name was given as 'Sijvert', 35 or, in the edition of $1516 / 1518$, as 'Zyevert', 36 which is, however, an equivalent of 'Sievert' or 'Siegwart', but not of 'Siegfried'. But that remains speculative. Anyway, Vosmeer was inclined to come up with fanciful philological constructions. Probably he was the one who invented the Greek-sounding names 'Zyphridus' and 'Lutcharis', and who "corrected" the name of the supposed father of Lutcharis, 'Theophanus', into 'Theophanes'; and it was certainly Vosmeer who transformed the Byzantine emperor into an epic 'Trojan' ('Dardanus') of Virgilian dimensions, thus adding to his pedigree by substituting Trojan for Hellenic blood. This is not so in his source, the Haarlem series of counts' portraits; there, he is properly referred to as 'the emperor of the Greeks. ${ }^{37}$

\section{From Habsburg Propaganda to Identity Formation of Holland's Cities and Families: The Haarlem Panels}

There was another way in which Vosmeer and Galle's pro-Habsburg portrait series was connected to the Habsburgs' political agenda: it harked back to the portrait series of the Counts of Holland that was rediscovered at Haarlem in 1573 in the Carmelite monastery. This series was painted on large wooden panels between 1486 and 1491. Each portrait is accompanied by a caption in Dutch

34 Vosmeer, Principes Hollandiae, p. 12: 'Didericum prius, hinc Zyphridum sustulit uxor'.

35 Cf. the edition in van Anrooij (ed.), De Haarlemse gravenportretten, "Bijlage" II, p. 125, line 73 .

36 Cf. ibidem, "Bijlage III", p. 166, line 73.

37 Cf. ibidem, "Bijlage II", p. 125, lines 68-69. 
verse by an anonymous poet. ${ }^{38}$ The series was financed by the Holy Roman Emperor, Maximilian I, who probably had a propagandistic aim in mind. Whatever its particular intent, this portrait series must certainly have been meant as a tribute to the Habsburgs and a sign of loyalty to Maximilian, to whom the final portrait of the series was dedicated. ${ }^{39}$

That Vosmeer and Galle's series recapitulates the Haarlem portraits of the Counts is immediately apparent even from the title page [cf. Fig. 10.2], where we read that the paintings were recently rediscovered 'on very old walls' by the glass painter Willem Thybaut (ca. 1524-1597 or 1599$)^{40}$ when serious damage was incurred to the Carmelite monastery during the 1573 Siege of Haarlem. The wording that the paintings were discovered 'on very old walls' suggests that they were mediaeval in origin, from earlier than 1300 at least. This assertion was intended to boost the prestige of the paintings - and thus also of the reproductions. We also read on the title page that the old paintings were copied faithfully and that Galle painstakingly transferred Thybaut's drawings into engravings.

It is, incidentally, not true that Galle carefully reproduced Thybaut's drawings; it would be fairer to say that he was highly creative and free-spirited with the material. For instance, the print of Dirk I is - aside from the long sword and the coat of arms - not a faithful likeness at all of the painting of Dirk [Figs. 10.4, 10.6 and 10.7]. In the painting, Count Dirk I is an aged man with a long white beard [Fig. 10.7]: in Galle's print, he is a young and beardless man [Fig. 10.4]. Dirk II in the painted version has a long dark beard and wears a fantastical headdress of bright colours [Fig. 10.6]; in Galle's print, we see no beard but we do see a knight's helmet with open vizier [Fig. 10.6]. Similar observations can be made with respect to almost all of Galle's engraved portraits: they differ from their painted precursors in bodily attitude, age, attire, facial expression and hairstyle. The series was primarily concerned with establishing the counts' legitimacy; a legitimacy which depended neither on accuracy of representation of individual facial characteristics (most of which were of course entirely unknown to posterity anyway) nor on faithful copying of the Haarlem portraits. What was considered vital, however, was that the portraits be 'true

38 For the series, see van Anrooij (ed.), De Haarlemse gravenportretten; for the dating, see $16-18$.

39 Falkenburg R., "Politiek en propaganda omstreeks 1490", in van Anrooij (ed.), De Haarlemse gravenportretten 69-72, here 71 .

40 Cf. Winter J.M. van, "Willem Thybaut en de Hollandse gravenportretten", Spieghel historiael 6 (1971) 614-623; Ruyven-Zeman Z. van, "Willem Thybaut”, in Luijten G. - Suchtelen A. van - Baarsen R. et alii (eds.), The Dawn of the Golden Age. Northern Netherlandish Art 1580-1620 (Zwolle: 1993) 493-500 [exhibition catalogue, Rijksmuseum, Amsterdam]. 


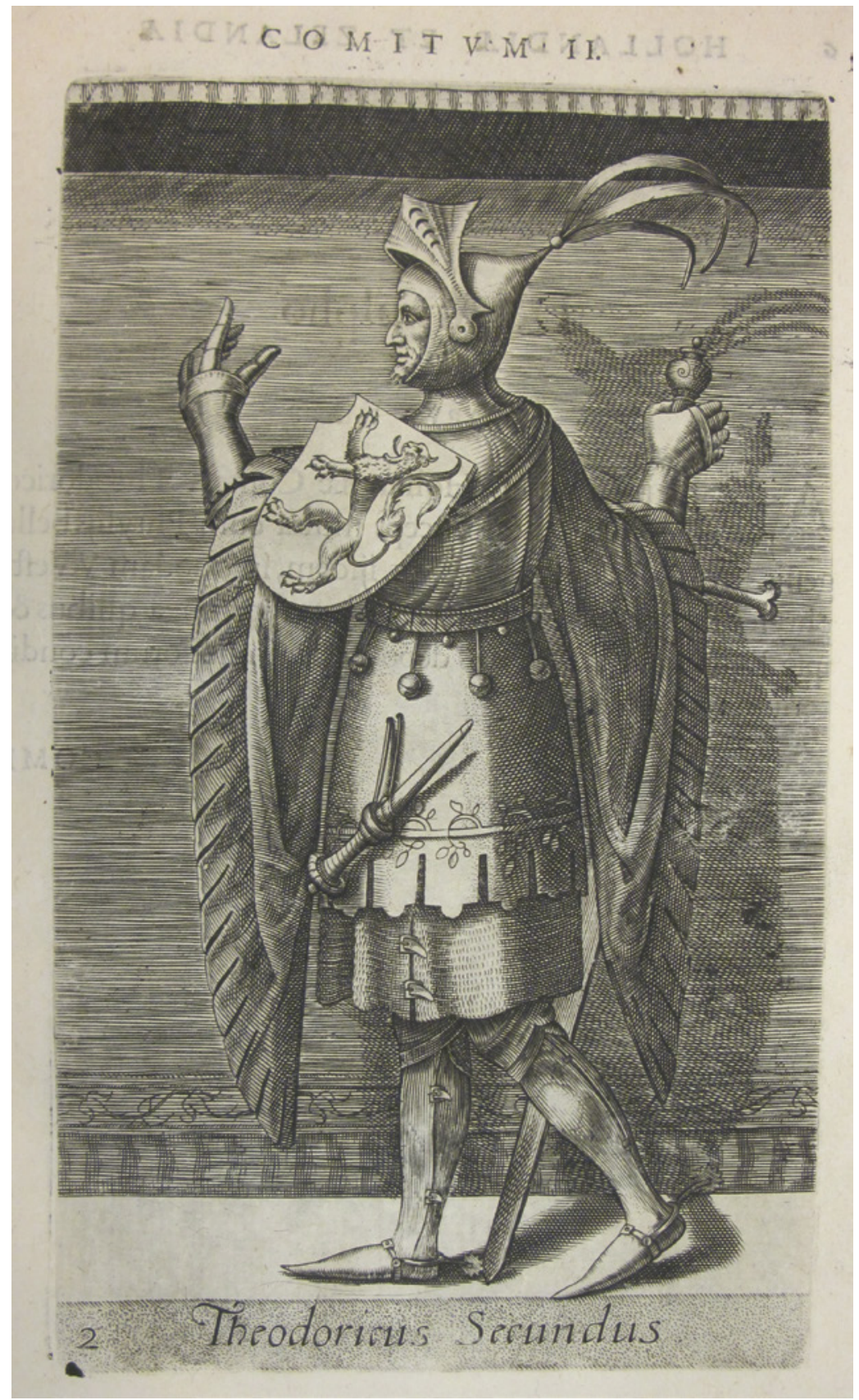

FIGURE 10.6 Dirk II, the Second Count of Holland. Engraving by Philip Galle, taken from: Michiel Vosmeer, Principes Hollandiae et Zelandiae, domini Frisiae (Antwerp, Christopher Plantin: 1578) 5

IMAGE @ UTRECHT UNIVERSITY LIBRARY 


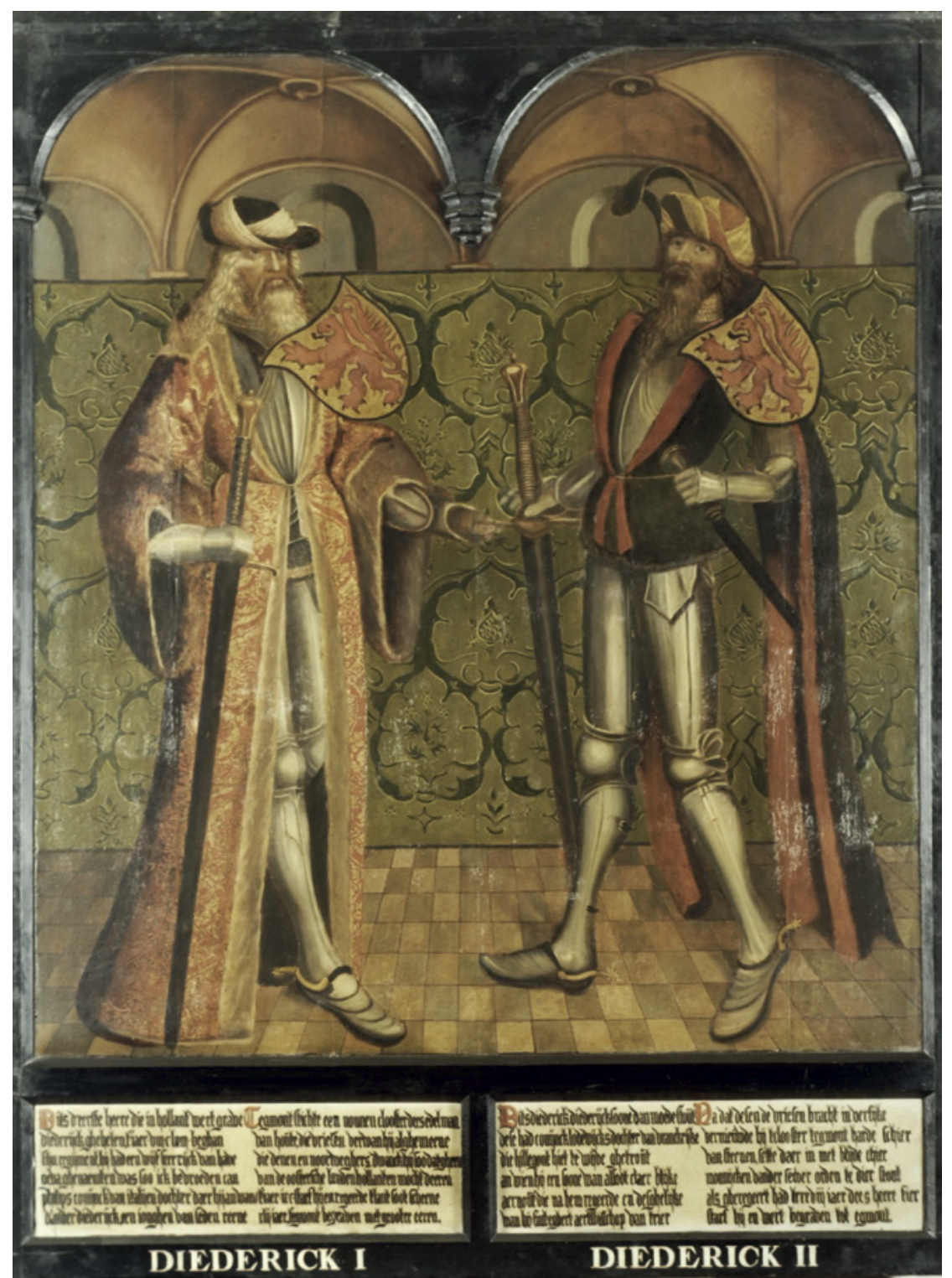

FIGURE 10.7 Dirk I (Diederick I) and Dirk II (Diederick II), the First and Second Counts of Holland. Haarlem, Town Hall, Gravenzaal, second painted panel in the series Counts of Holland (ca. 1486-1491). Oil on panel IMAGE (C) NOORD-HOLLANDS ARCHIEF, HAARLEM 
to life' (ad vivum), but this was a term interpreted freely and in varied ways in the sixteenth and seventeenth centuries. With respect to Galle's engravings, ad vivum did not mean much more than that the portraits resembled real human beings.

In the Haarlem painting cycle, the anonymous writer reveals the origins of the Counts of Holland in Dutch poems, placing the historical narrative in the mouth of a herald (depicted on the first panel) [Fig. 10.8]. The account bears similarities with Vosmeer's version, although there are also a number of discrepancies. In the herald's account, 'Aquitania brought forth a youngest son, to whom he (his name was Charles the Bald) gave Holland in perpetuity'.41 The unnamed Duke of Aquitania lived under the reign of Pepin the Short, King of the Franks (r. 751-768), founder of the Carolingian dynasty and father of Charlemagne. ${ }^{42}$ This Duke of Aquitania, as the account wants to have it, was himself a scion of the Carolingian family and had the right to use the house's crest, the one bearing the lilies (or fleurs-de-lys). However, we are told, Pepin was determined to monopolise power, so he denied all other branches of the family the right to use the lily crest. According to the account, the (unnamed) Duke of Aquitania, complied and immediately substituted the old crest of Troy, the lion, for the lily emblem:

Van Aquijtanijen die hertoch en dorst hem niet reuen, $\mathrm{Al}$ was hij ghecommen van sconijncx stam.

Hij liet de lelijen ter selver euren

Ende dit wapen van Troijen hij wedernam. ${ }^{43}$

The Duke of Aquitania dared not defy this, / Although he descended from the royal lineage. / He immediately abandoned the lilies / And took up this crest of Troy again.

It was then, we are told, the youngest son of this Duke of Aquitania, Dirk, who migrated to Holland and brought the heraldic symbol of Troy with him:

Een leeuw van keel te voeren plaghen [cf. Fig. 10.9A]

Int velt van ghulden, Trojaens gheslacht.

41 Cf. the edition in van Anrooij (ed.), De Haarlemse gravenportretten, section "Aquitanië en de herkomst" 119 and 121.

42 Ibidem 119.

43 Ibidem. 


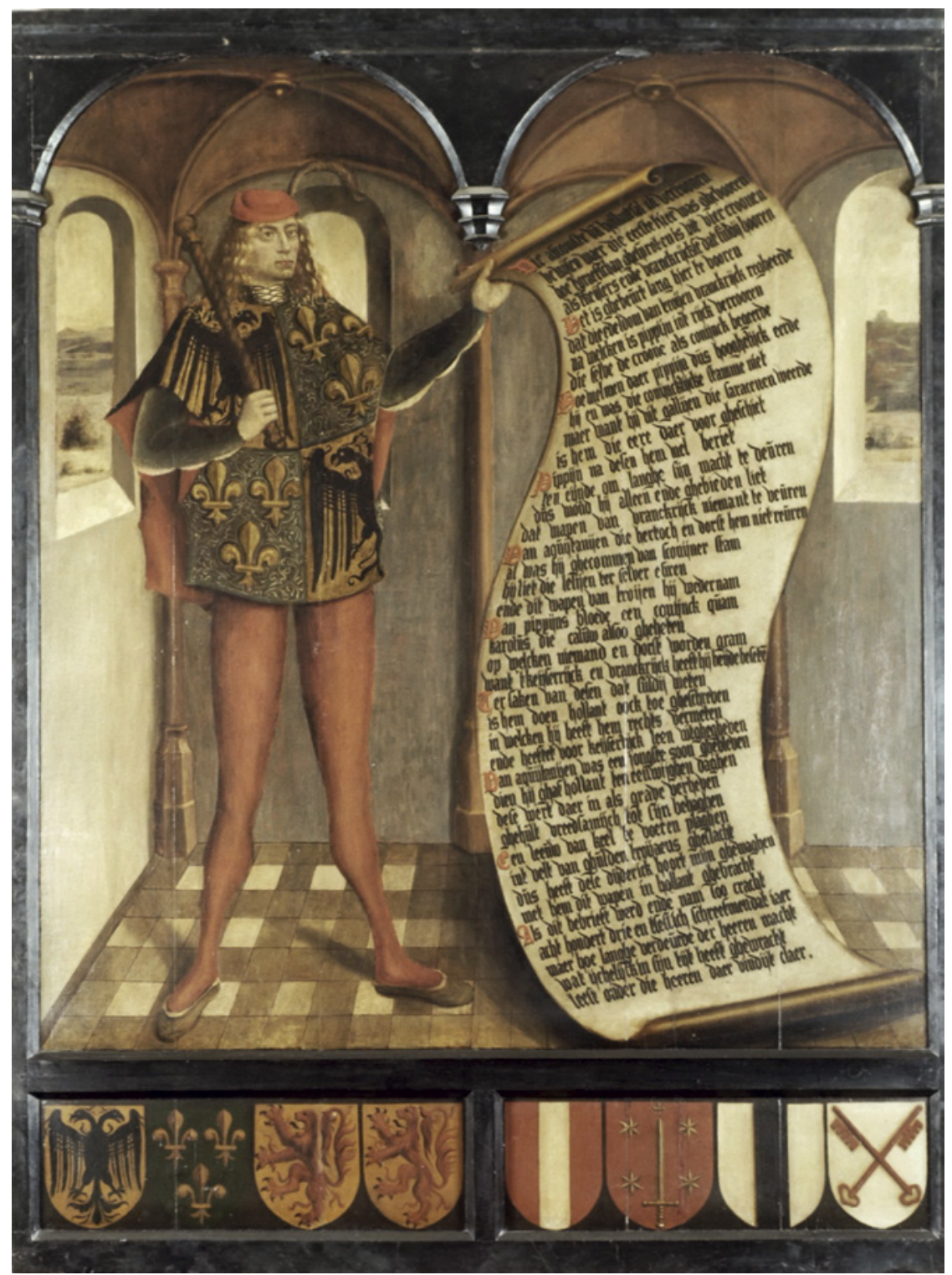

FIGURE 10.8 Herald narrating the origins of the Counts of Holland. Haarlem Town hall, Gravenzaal, first painted panel in the series Counts of Holland (ca. 1486-1491). Oil on panel

IMAGE (C) NOORD-HOLLANDS ARCHIEF, HAARLEM 


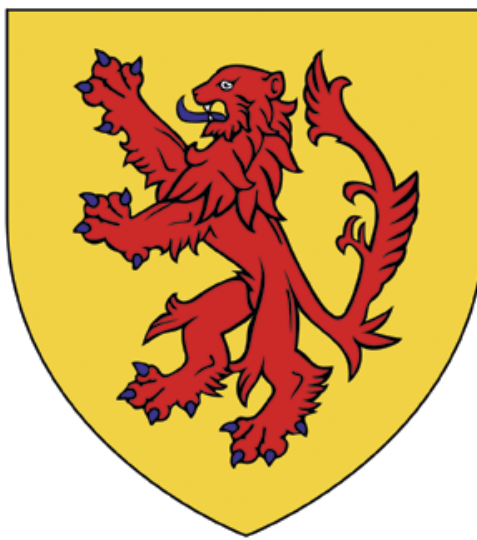

FIGURES 10.9A Coat of arms of the Counts of Holland: red lion on yellow field

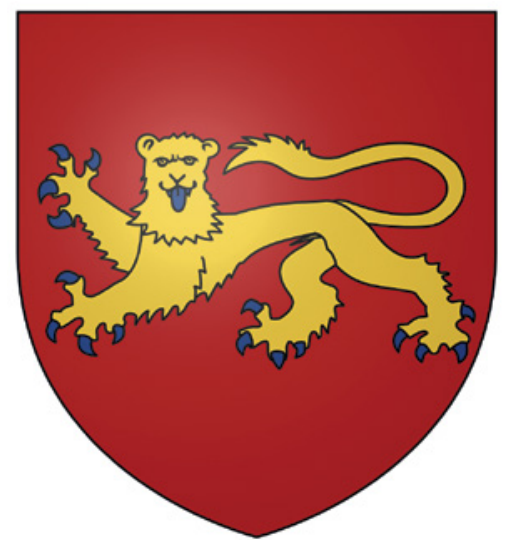

FIGURE 10.9B Coat of arms of Aquitania (from 1259 onwards): yellow lion on red field

Dus heeft dese Dijderick, hoort mijn ghewaghen, Met hem dit wapen in Hollant ghebracht.

A red lion on a field of gold [cf. Fig. 10.9A] / The Trojan race used to bear as its arms. / So this Dirk, attend to my account, / Took these arms with him to Holland.

The background to this story is that the Dukes of Aquitania bore a lion in their coat of arms, as did the renowned Trojans of old [Fig. 10.9B]. It was thus presumed that the house itself must hail from Troy. In a marked difference from Vosmeer, the writer of the captions to the Haarlem portraits does not give the name of the 'Duke of Aquitania'. The name Dirk he does give to the Duke's son, but nevertheless he deliberately refuses to call Dirk Duke of Aquatania. Might he have feared that historical imagination would come to be seen as historical fraud?

It is indeed the case that historical and chronological problems - far from trivial ones - lurk behind this family tree construction. For one thing, in Pepin the Younger's reign $\left(75^{-}-768\right)$, the throne of the Duchy of Aquitania was occupied not by a 'relative', but by a certain Waifar. This Waifar, who as it happens had not a drop of Trojan blood (not even suspected) in his veins, was not the kind of man to accede to the king's authority as the imaginary relative of Pepin is said to have done. Quite the contrary: Waifar waged furious warfare against Pepin the Younger for seven years, costing him his duchy and his life. Another 
problem with the claim is that Pepin the Younger's regnal dates do not remotely match the year $(858)$ to which the Haarlem portrait series dates the gift of Holland. ${ }^{44}$ There is around a hundred years' difference. Pepin the Younger can in no way have been a contemporary of Dirk's father or Dirk himself.

Yet another issue is that in the Carolingian era, there was no duke or any other ruler of Aquitania who bore a lion in his crest. This heraldic design reached Aquitania only as late as 1259, when the Treaty of Paris awarded Henry III of England (1207-1272, r. from 1216 onwards) a subdivision of the old Duchy of Aquitania (namely the coastal regions of Saintonge and Gascony), which from then on became known as Guyenne. Moreover, the animal on the crest of this new Guyenne is the English lion, not the Trojan and not the one of the counts of Holland [Figs. 10.9A and B].

While the author of the poems accompanying the Haarlem series clearly claims Aquitanian and Trojan origins for the Counts of Holland, he mostly did not think this up himself. The stories of the Trojan origins of the Counts had already cropped up in the fourteenth century. ${ }^{45}$ The writer of the Haarlem captions was generally following genealogical constructions which he encountered in his sources. He was doing so, too, in his claim that Dirk I was married to the daughter of Pepin King of Italy (781-810), son of Charlemagne, a daughter whom he calls not 'Gena', but 'Geva':

Hij [Dirk I] had een wijf seer rijk van have, Geva ghenaemd, en was, soo ick bevroeden can, Pippijns conijnck van Italijen dochter, daer hij aan wan Dander Diederijck, een jongen van seden reene. ${ }^{46}$

He [Dirk I] dad a very wealthy wife, Named Geva, who was - as far as I can see [or: judge]

Daughter of Pepin, King of Italy; from her he took

Dirk II, a virtuous boy.

Here the phrase 'soo ick bevroeden can' - 'as far as I can see [or: judge]' indicates that the author of the Haarlem captions was a bit sceptical about this genealogical link with the Carolingians he found in the chronicles, and, via

44 Ibidem, 123: 'tjaer viIIc LVIII beghan / Sijn regijment [...]' - 'His reign began in the year $85^{8}[\ldots]$...

45 van Anrooij, "Aquitanië en de herkomst". Cf. the discussion above.

46 Cf. the edition in van Anrooij, De Haarlemse gravenportretten 123, "Dierderick I", lines 44-47. 
them, about the Counts' affiliation with the Trojans of old. However, he was not aware of the fact that Pepin of Italy had no daughter with the name 'Geva' (or with a similar name), and, actually, no daughter at all Dirk I could have married. ${ }^{47}$ In the end, the author of the Haarlem captions transmitted the genealogical implant without any specific historical criticism. ${ }^{48}$

The same is true for the pedigree of Arnout's consort, who was supposed to be the daughter of a Byzantine emperor. In the account of the author of the Haarlem captions the genealogical construction and its origin, i.e., the connection with Theophanou, Holy Roman Empress, become even more evident. The author plainly says that 'Luijtgaert' was not only the daughter of the Greek Emperor 'Theophanus', but also the sister of Theophanou, 'the famous Holy Roman Empress':

Aernout, Diedericx soone, regeerde daer na

En had een vrouwe geheeten Luijtgaert.

Theophanus, de keijser van de Griecken, soo ik versta,

Was haer vader, en die Roomsche keijserinne vermaert

Haer suster. ${ }^{49}$

Arnout, son of Dirk, reigned thereafter,

And had a consort called Luijtgaert.

Her father was, as far as I see, Theophanus,

And the famous Holy Roman Empress [i.e. Theophanou] was her sister.

Now it also becomes clear that the genealogical construction had two goals: first to link the Counts of Holland with the Byzantine emperors, second with the Ottonian dynasty, the family of the Holy Roman Emperors; of course both links added very much to the splendour of the Counts' nobility. Interestingly, there

47 Cf. the discussion in the previous section.

48 The author of the Haarlem captions was not aware of the tradition that Dirk II was married with Hildegarde, who is regarded a daughter of Count Arnulf I of Flanders. If Hildegarde was indeed the daughter of Arnulf of Flanders (and not his wife), she could boast of a descent from Charlemagne. Because the the Carolingians traced their family tree back to King Priam of Troy, this would mean that, via Hildegarde, another line of Trojan blood would be added to the genealogy of the Counts of Holland. De Boer Cordfunke, Graven van Holland 23, plainly state that 'Graaf Arnulf [...] via zijn moeder stamde hij [...] af van de Karolingen'.

49 Cf. the edition in van Anrooij, De Haarlemse gravenportretten 125, "Aernout I", lines 66-70. The French version of 1516/ 1518 renders 'Lutgaert's' pedigree in this way: 'Lutgaert [...], / La fille Teophanus [sic], empereur de Grece, tant renomme, / Et lemperesse de Romme tant louable fut sa soeur' (ibidem, "Bijlage III", p. 167, lines 71-72). 
were indeed close connections between Emperor Otto II, and Theophanou, and the counts: Arnout was among the cortege of twelf noblemen chosen to accompany the couple to Rome in 980, for their coronation as Holy Roman Emperor and Empress [Fig. 10.10]; in the same year Otto II honoured Arnout through attending his wedding with Lutgardis, and especially through acting as his best man. ${ }^{50}$ The close ties between the Counts of Holland and the Ottonian dynasty of the Holy Roman Empire remained alive even after Arnout's sudden death in 993: his widow Lutgardis (d. After 1005) received military and political support first by Emperor Otto III and Theophanou (983-1002), and thereafter by Otto III's son Henry II (973-1024,), who became Lutgardis' brother-in-law via her sister Cunigunde of Luxembourg (ca. 975-1040). Henry married Cunigunde in 1002 when he was coronated Roman King of the Germans (Rex Germanorum) and his consort 'Queen of the Germans'. As Theophanou, Cunigunde of Luxembourg became regent of the Holy Roman Empire, after her husband's death in 1024 .

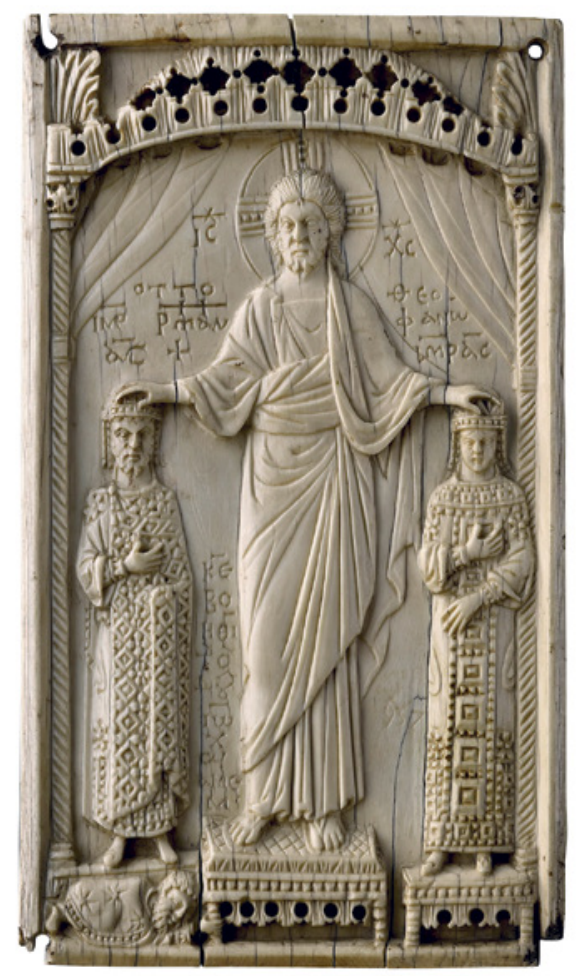

FIGURE 10.10

The coronation of Otto II and Theophanu as Holy Roman Emperor and Empress (982). Ivory panel, $18.5 \times 10.6 \mathrm{~cm}$. Musée de Cluny, Paris

IMAGE (C) MUSÉE DE CLUNY, PARIS

5o Cf. de Boer - Cordfunke, Graven van Holland 23. 
Here again, the author of the Haarlem captions displays a kind of cautious attitude (it appears from the words 'soo ick versta' - 'as far as I see), ${ }^{51}$ but nevertheless transmits the fantastical genealogical construction he had found in the chronicles. Evidently, he was himself not quite convinced, but on the other hand, he had apparently not the historical knowledge which would have been necessary to reject the claim. He was not aware of the fact that in reality there had never existed a Byzantine emperor with the name 'Theophanus', that the real father of Theophanou was not emperor 'Theophanus' or another Greek emperor, but general Konstantinos Skleros, brother-in-law of Emperor Johannes Tzimiskes I (Skleros' sister Maria had been the first wife of Johannes Tzimiskes), and that Arnulf's wife was not the sister of Theophanou, but the daughter of count Siegfried of Luxembourg, and sister of Cunigunde.

Although the Haarlem panels painted around 1490 were probably intended as a piece of pro-Habsburg propaganda, it must be borne in mind that their propagandistic effect remained limited to those who visited the Haarlem Carmelite monastery and saw them there. As the sixteenth century progressed, however, more potent media became available to carry these propagandistic aims out into society: primarily, printed images such as woodcuts, engravings and etchings. Printed imagery obviously had a much amplified propaganda effect compared with paintings. Prints could be disseminated in large print runs, reaching a much wider public. Printed portraits could end up anywhere in the Low Countries and even beyond. The 1578 engravings made by Philip Galle were published by the renowned printer and bookseller Christopher Plantin, who had a network spanning Europe. Plantin ensured that the Counts of Holland were disseminated as best they could be. Galle's series was a huge success: his Counts of Holland were reprinted several times during the Dutch Revolt (with various authors' texts), in 1583, 1584 (the year of William the Silent's assassination) and $1586,{ }^{52}$ both in the Northern and the Southern Netherlands. ${ }^{53}$

The usefulness of publicly displaying portraits was something also grasped in sixteenth-century Haarlem: it was no coincidence that in the same year in which the Haarlem artist Galle engraved the portraits, the painted ones were transferred to a key public space: they were moved from the Carmelite

$51 \quad$ Ibidem 125 .

$5^{2}$ The prints were used as illustrations for the book Galle Philip, Les vies et alliances des comtes de Hollande et Zélande, signeurs de Frise, published at Antwerp by Christopher Plantin (1583 and 1586); and in 1584, to illustrate Hadrianus Barlandus's Latin prose series on the Counts of Holland, Hollandiae Comitum historia et icones [...] (Christopher Plantin, Leiden: 1584).

53 The work was originally published under the title Barlandus Hadrianus, De Hollandiae principibus (Antwerp, Johannes Theobaldus: 1519). Cf. Haitsma Mulier E.O.G. - Lem G.A.C. van der (eds.), Repertorium van geschiedschrijvers in Nederland (The Hague: 1990) 21. 


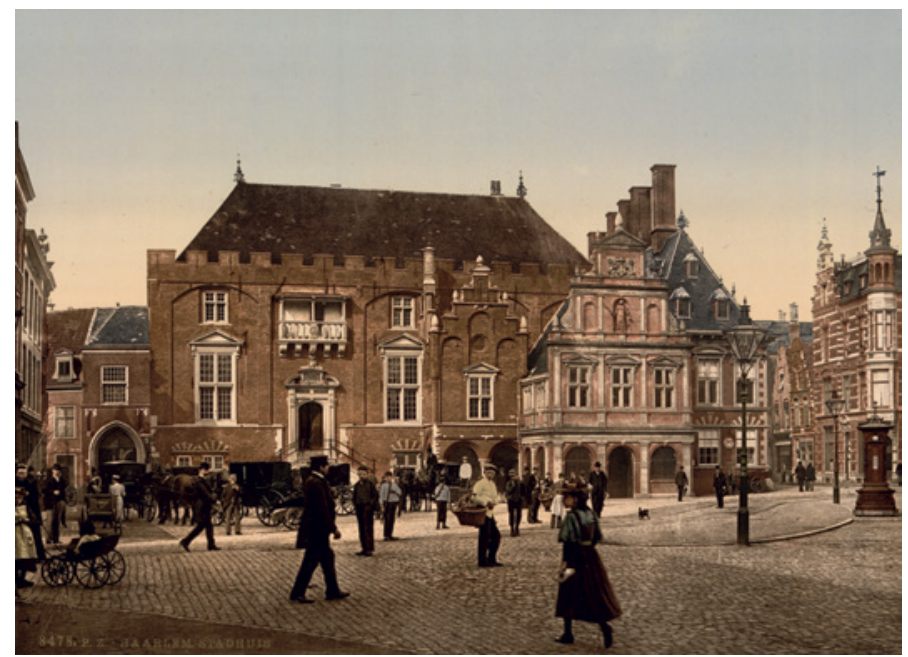

FIGURE 10.11 Haarlem Town Hall

IMAGE (C) NOORD-HOLLANDS ARCHIEF, HAARLEM

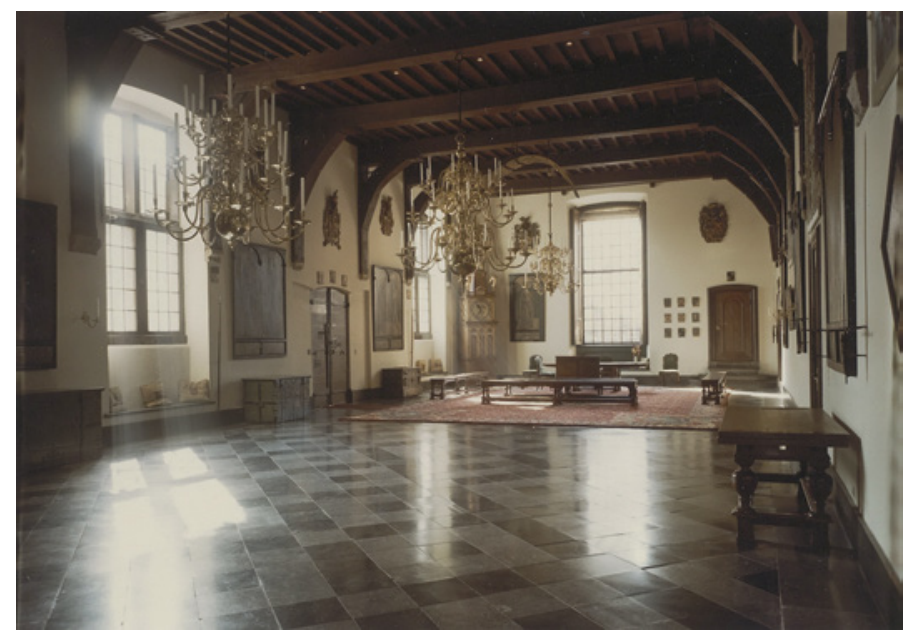

FIGURE 10.12 The Gravenzaal in the town hall of Haarlem

IMAGE (C) NOORD-HOLLANDS ARCHIEF, HAARLEM

monastery to the great reception hall of Haarlem Town hall [Fig. 10.11], which thereupon acquired the name Gravenzaal (Hall of Counts) [Fig. 10.12]. ${ }^{54}$ There, they served a different purpose than they had in the cloister: one more focused

54 Cf. Bueren T. van, "Van karmelietenklooster naar stadhuis", in Anrooij W. van (ed.), De Haarlemse gravenportretten. Hollandse geschiedenis in woord en beeld (Hilversum: 1997) 73-77. 
upon Haarlem city council's political agenda. The city fathers were probably wanting to use the portraits of the counts to remind visitors of the city's privileges, which had been honoured by the Counts of Holland up to and including Emperor Charles V. ${ }^{55}$ It is fairly certain, though, that there were more intentions besides: by putting the portraits on display, the city was seeking to boost its prestige as one of Holland's leading cities. Actually, Dordrecht had the honour of being Holland's oldest and most prestigious city, because it was said to have been founded by Count Dirk I, who had his residence there on the dike. Haarlem had been founded later (by Count William II) and held only second place chronologically. By publicly exhibiting a portrait gallery of the Counts of Holland in its 'city fortress', Haarlem was now giving itself out to be the hub of power in Holland and was profiling itself - at least in an ideal sense - as the counts' true home city. ${ }^{56}$

Other cities envied Haarlem's portraits of the counts. It is, then, no surprise that the painter who had discovered the portraits of the Counts of Holland and first copied them, Willem Thybaut, ${ }^{57}$ was commissioned by other cities in the Province of Holland. In 1587-1588, he was working on stained-glass windows in grisaille with of the Counts of Holland for the militia hall (Schuttersdoelen) at Leiden [Fig. 10.13], of which twelve windows with the portraits of Counts survive (in Museum De Lakenhal at Leiden) ${ }^{58}$ [Figs. 10.14 and 10.15], and furthermore 35 templates (cartoons) which are preserved now in the Municipal Archive at Leiden. ${ }^{59}$ Interestingly, Thybaut depicted several of the Counts as fancifully oriental, i.e. Trojan, princes with a turban adorned with a bunch of feathers, e.g. Count William I [Fig. 10.15]. Of course, this was an important ideological statement that the Counts of Holland had been chosen as historical figures to adorn the Schuttersdoelen: they were supposed to serve as examples of virtue for the members of the militia of Leiden and, thus, for the defenders of the Dutch Revolt. For the same reasons, between 1580 and approximately 1650 , public spaces in the cities of Holland were festooned with series of portraits of the Counts of Holland. Unfortunately, quite a number of them have been lost.

$55 \quad$ Ibidem 73 .

56 Volmert, Grenzzeichen und Erinnerungsräume 75. Incidentally, the conclusions that Volmert draws from the publication of the series by Vosmeer and Galle are wrong; see footnote 8 .

57 Cf. van Winter, "Willem Thybaut en de Hollandse gravenportretten".

$5^{8}$ Museum De Lakenhal, inv. nos. 349-36o.

59 Cf. Vogelaar C., "De gravenramen door Willem Thybaut", Lakenhal nieuws 1,9 (1996); Pelinck E., "De gravenramen van Willem Thybout en andere merkwaardigheden van de Leidse Doelens", Jaarboekje voor geschiedenis en oudheidkunde van Leiden en omstreken 43 (1951) 85-91; Ruyven-Zeman Z. van, "Willem Thybaut" 493-500; de Jong, "Gravenportretten" 209, no. 13. 


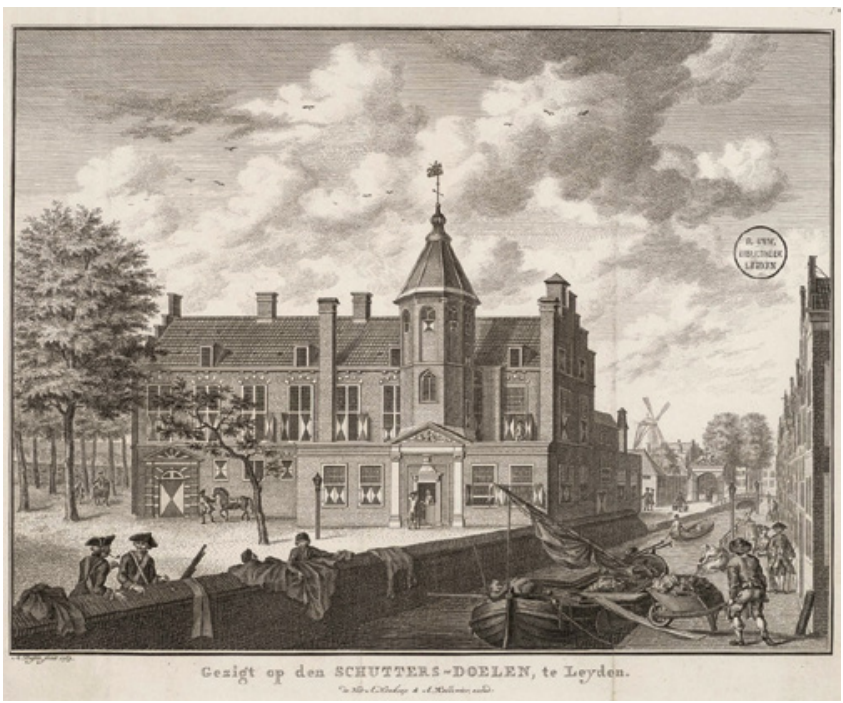

FIGURE 10.13 The militia hall (Schuttersdoelen) at Leiden. Engraving by Abraham Delfos, taken from: Frans van Mieris, Beschrijving der stad Leijden, 2 vols. (Leiden: 1770), vol. II, 408. The building was demolished in 1821 IMAGE (C) PRENTVERZAMELING GEMEENTELIJKE ARCHIEFDIENST LEIDEN

From 1578 onwards, series of portraits of the Counts also started finding their way into the castles of the Dutch nobility. For example, in 1585 Johan II van Duivenvoorde (1547-1610), Lord of Warmont, who in 1576 was appointed Admiral of the Lakes of Leiden and Haarlem and who was regarded as one of the most important military leaders of the Dutch Revolt ${ }^{60}$ commissioned Willem Thybaut to produce a series of paintings of the Counts of Holland for his castle of Warmont (nowadays Huis te Warmond) [Figs. 10.16 and 10.17]. There is no doubt that Johan II van Duivenvoorde did so to raise his prestige as a nobleman. He saw the Counts of Holland as his forefathers and as the guarantee of his family's high standing. If this was true of the van Duivenvoordes, it was no less true of other noble houses. In some cases, such as that of the Brederodes, there was additionally a claim to a direct genealogical link, ${ }^{61}$ but in others, the issue was historical identity formation and prestige in a broader sense.

6 Cf. Steur A.G. van der, "Johan van Duvenvoirde en Woude (1547-1610), heer van Warmond, admiral van Holland", Hollandse studiën 8 (1975) 179-273.

61 Cf. also Beelaerts van Blokland W.A., "Stamreeksen in beeld. De graven van Holland en de heeren van Brederode door Jacob Cornelisz. van Oostzanen en Cornelis Anthonisz.", De Nederlandse leeuw 51 (1933) 202-207. 


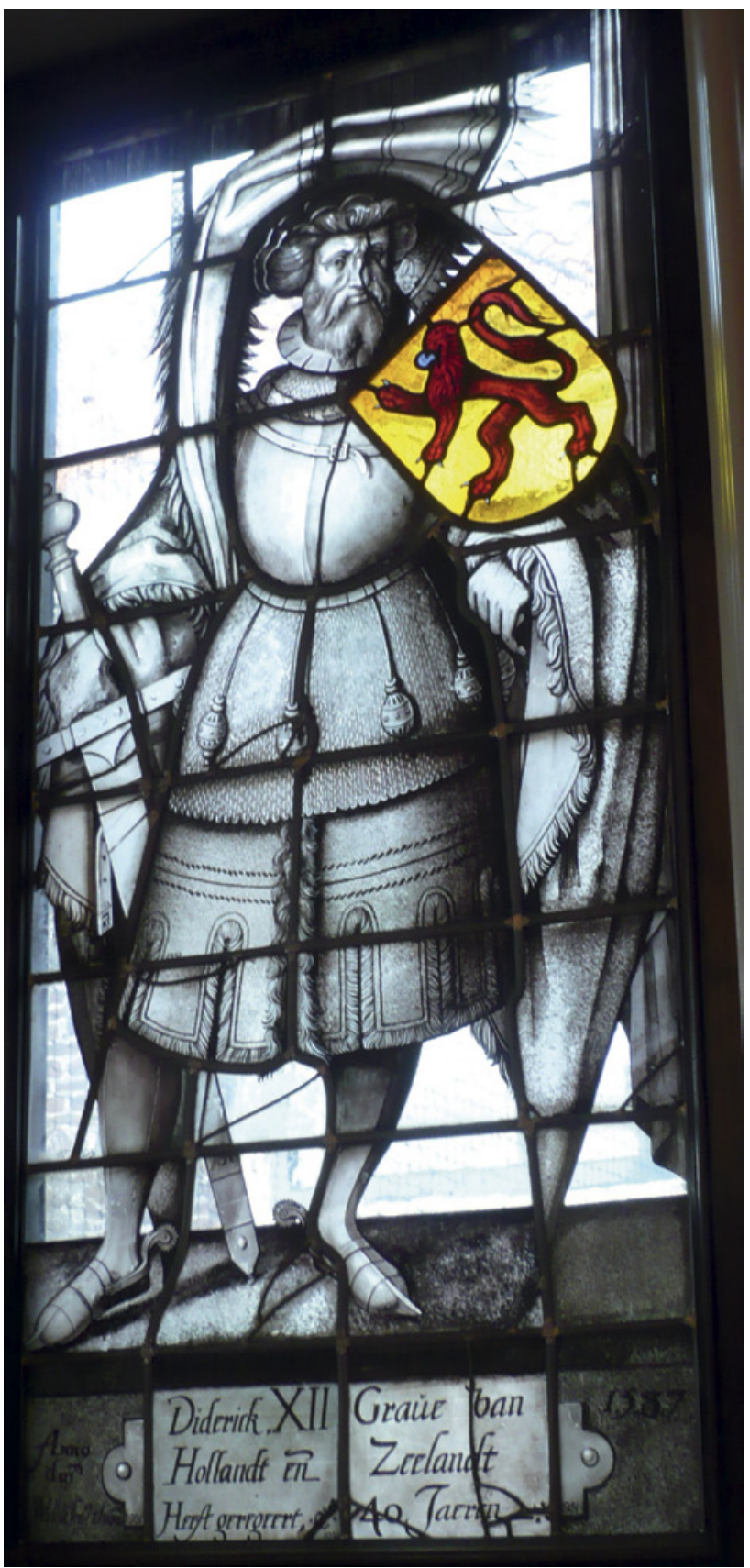

FIGURE 10.14 Willem Thybaut, Dirk VI, Count of Holland (1587). Stained-glass window made for the Schuttersdoelen of Leiden, $141 \times 66 \mathrm{~cm}$

IMAGE (C) MUSEUM DE LAKENHAL, LEIDEN 


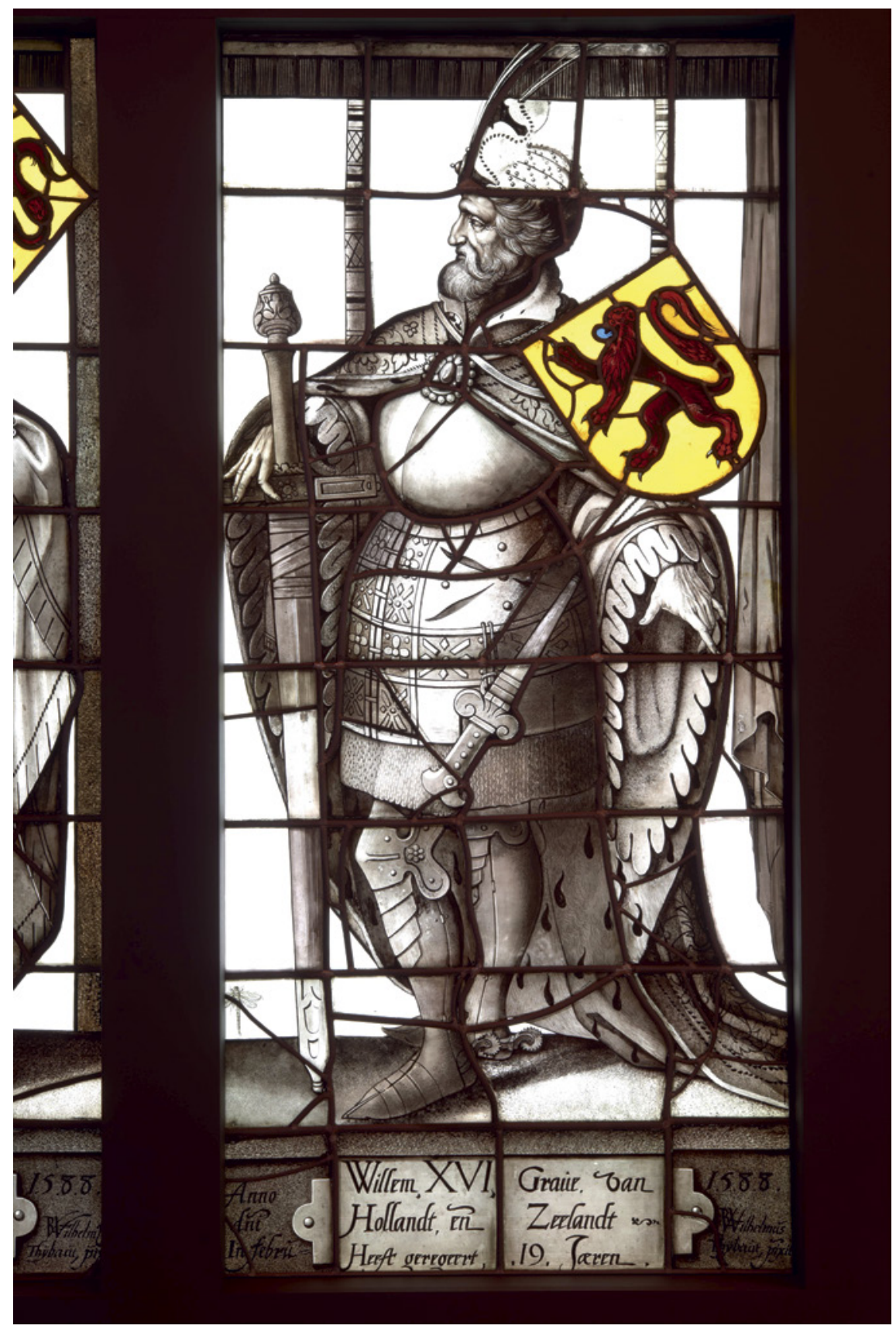

FIGURE 10.15 Willem Thybaut, William I, Count of Holland (1587). Stained-glass window made for the Schuttersdoelen of Leiden, $141 \times 66 \mathrm{~cm}$ IMAGE (C) MUSEUM DE LAKENHAL, LEIDEN 


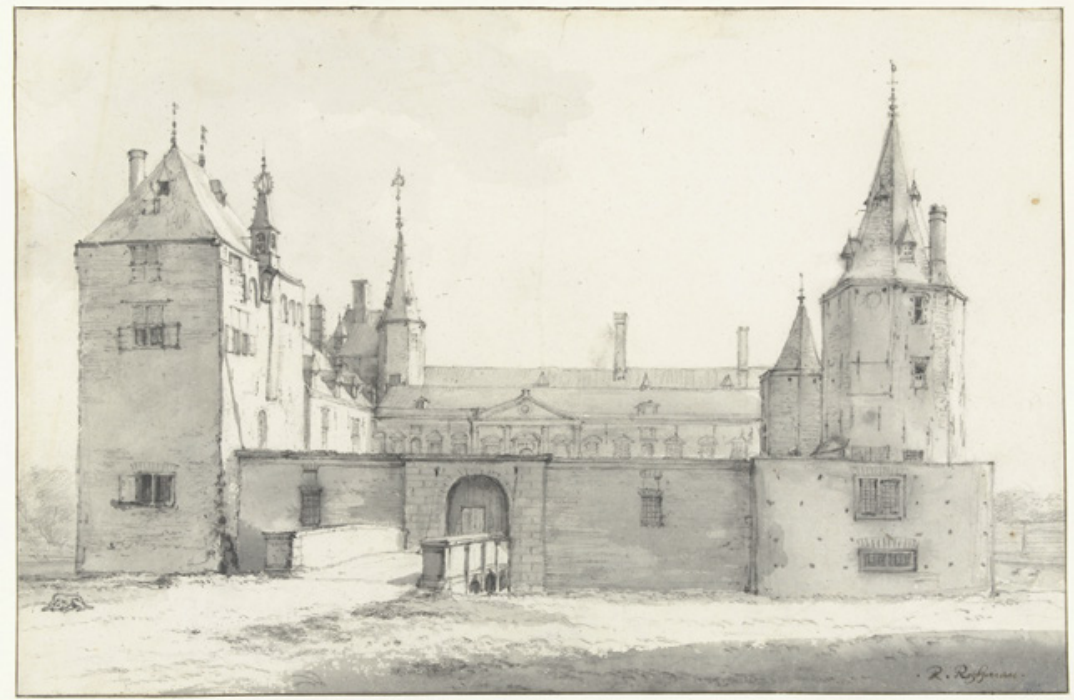

FIGURE 10.16 Roeland Roghman, The Castle of Warmond (ca. 1650). Drawing $31.2 \times 47.6 \mathrm{~cm}$. See also Fig. 12.5 IMAGE (C) RIJKSMUSEUM, AMSTERDAM

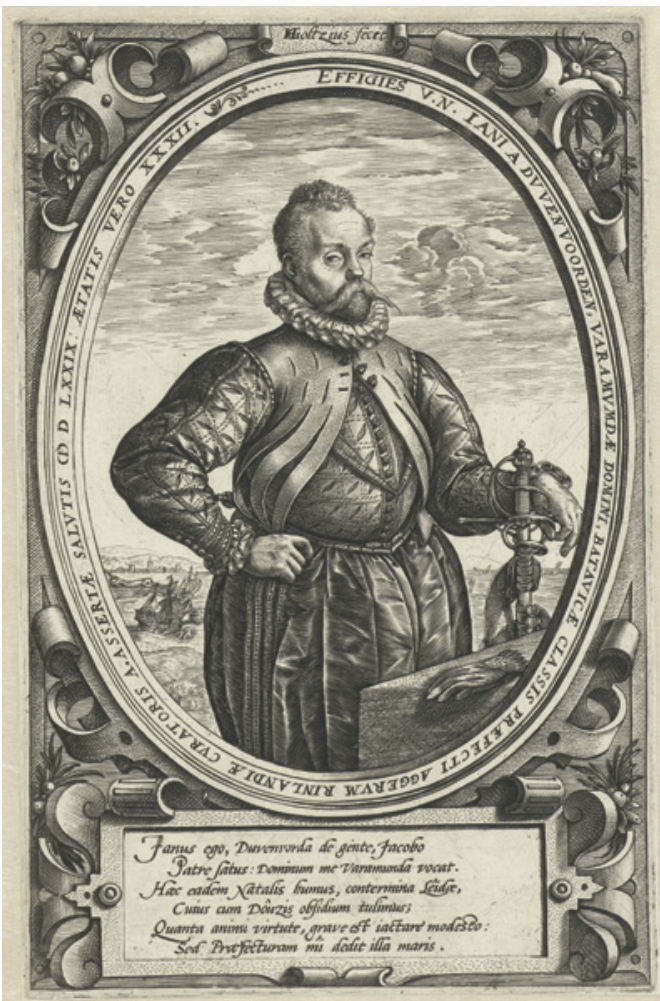

FIGURE 10.17

Johan II van Duivenvoorde (1547-1610), Lord of Warmond, at the age of thirty-two (1579). Engraving by Hendrik Goltzius IMAGE @ RIJKSMUSEUM 
The value and impact of printed series of portraits gradually became apparent across Europe during the sixteenth century. ${ }^{62}$ As the century wore on, and particularly in its latter half, the number of printed portrait series burgeoned. Some of the most highly influential of all were Heinrich Pantaleon's (1522-1595) series Prosopographia heroum atque illustrium virorum totius Germaniae (1565-1566) ${ }^{63}$ and, in German, Teutscher Nation Heldenbuch (1567$1570 ; 1578),{ }^{64}$ comprising in total 1700 portraits; the series of portraits of the

62 Cf. Pelc M, Illustrium imagines. Das Porträtbuch in der Renaissance (Leiden - Boston: 2002).

63 Pantaleon Heinrich, Prosopographia heroum atque illustrium virorum totius Germaniae, opus plane novum [...], ex omnium fere gentium chronicis, annalibus et historiis magna diligentia excerptum et vivis heroum imaginibus [...] illustratum, ac nunc primum ob patriae decorem in lucem editum, ita quod instar continuae historiae Germanorum esse queat [...] (Basel, Nicolaus Brylinger: 1565).

64 Pantaleon Heinrich, Teutscher Nation Heldenbuch: Inn diesem werden aller Hochuerrümpten Teutschen Personen, Geistlicher vnd Weltlicher, hohen vnnd nideren staths, Leben vnnd nammhafftige thaten gantz warhaftig beschriben, welliche durch jhre tugendt, grosse authoritet, starcke waffen, frommkeit, weißheit, vnd gute künst [...] jr vatterland Teutsche nation höchlich bezieret, vnd groß gemachet; mit sampt aller alten vnd neuwen Fürsten Teutscher nation Genealogey, Geburtstafflen vnd harkommen (Basel, Nicolaus Brylinger: 1567; ibidem: 1570); idem, Der ander Theil Teutscher Nation Heldenbuch: Inn diesem werden aller hochberümpten Teutschen Personen, Geistlicher und Weltlicher, hohen unnd nideren staths, Leben unnd namhaffte Thaten gantz warhafftig beschrieben [...] von dem Grossen Carolo [...] har, in die siebenhundert jar, biss auff Keyser Maximilian den ersten [...] / Erstlich durch den Hochgelerten Herren Heinrich Pantaleon fast auss aller voelckeren Historien [...] fleissig in Latein zusammen gezogen, unnd mit sampt aller beschribener personen büldtnussen [...] künstlich fürgestellet. Jetzmalen aber von dem [...] Authore selbs verteutschet, reichlich gemehret, und gebesseret [...] (Basel, Nicolaus Brylingers Erben: 1568); idem, Der dritte und letste Theil Teutscher Nation Heldenbuch: In diesem werden aller hochberümpten Teutschen Personen, Geistlicher und Weltlicher, hohen und nideren staths, Leben und nammhaffte Thaten gantz waarhafftig beschrieben [...] under den vier letsten Keyseren Maximilian I. Carolo V. Ferdinando, und Maximilian II. von dem 1500 biss auff das lauffende 1570 jar [...] / Erstlich durch den Hochgelehrten Herren Heinrich Pantaleon, zum theil auss vieler voelckeren Historien [...] in Latein zusamen gebracht, und mit sampt vieler personen bildnussen fürgestellet. Jetzmalen aber von dem Authore selbs verteutschet, reichlich gemehret, geenderet, und gebesseret [...] (Basel, Nicolaus Brylingers Erben: 1568); idem, Teutscher Nation warhafften Helden, Erstlich durch den Hochgelehrten Herren Heinrich Pantaleon, fastauß vieler völckern Historien, Chronecken, und geschichtrodlen, mit grosser arbeit fleissig zu Latein zusammen gezogen, und mit sampt aller beschriebener personen bildnussen (so viel möglich) künstlich fürgestellet. Jetzmalen aber von dem ersten Authore selbs verteutschet, reichlich gemehret, und gebesseret, auch zu lob Teutscher Nation inn Truck verfertiget. Also das der gemeine mann alle Teutschen Historien, von anfang der welt biß zu gemeldeter zeit, inn fürgestelleten Personen leichtlich vermercken. Allen Fürstlichen, Hohen 
master painters of the Low Countries by Domenicus Lampsonius (Dominique Lampsone, 1532-1599) and Hieronymus Cock (1518-1570), Pictorum aliquot celebrium Germaniae inferioris effigies (Antwerp: 1572), ${ }^{65}$ enlarged by Philip Galle (160o), and reissued by Theodor Galle (1615, with the title Illustrium quos Belgium habuit pictorum effigies), and Hendrik Hondius's (1573-1650) work on the same topic, Pictorum aliquot celebrium, praecipue Germaniae Inferioris effgies (1610);66 Philip Galle's series of important humanist scholars, the Virorum doctorum de disciplinis benemerentium effigies $(1572),{ }^{67}$ and the illustrated editions of Paolo Giovio's biographical series of great kings and military leaders (1575), and of great humanists (1577), accompanied by the woodcuts of Tobias Stimmer (1539-1584), which were published by the Italian printer Petrus Perna

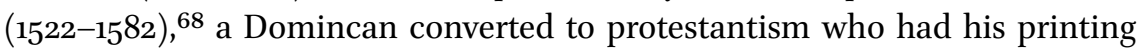
press in Basel, and Jean-Jacques Boissard's series of humanist scholars from the 14th to the 16th century, Icones virorum illustrium doctrina et eruditione praestantium (1597-1599). ${ }^{69}$ With his Prosopographia heroum atque illustrium virorum totius Germaniae and Teutscher Nation Heldenbuch, Heinrich Pantaleon delivered the public an awe-inspiring national honour gallery of German heroes. Domenicus Lampsonius, Hieronymus Cock and Philip Galle showed the public that the Low Countries had produced a great succession of brilliant painters; Giovio and his publisher Petrus Perna took for their gallery of

Rittermeßigen, und Adelspersonen Teutscher nation gantz lustig, kurtzweilig, und nutzlich von iren altvorderen und vorfaren zulesen (Basel, Oststein: 1578). For this work cf. especially Buscher H., Heinrich Pantaleon und sein Heldenbuch (Diss. Basel 1946) Basler Beiträge zur Geschichtswissenschaft, vol. 26, and Rave P.O., "Paolo Giovio und die Bildnisvitenbücher des Humanismus”, Jahrbücher der Berliner Museen 1 (1959) (119-154) 147-148.

65 Published and printed by the same Hieronymus Cock. For Lampsonius and his gallery of portraits cf. Denhaene G., Lambert Lombard: Renaissance et humanisme à Liège (Antwerp: 1990); Puraye J., Dominique Lampson humaniste, 1532-1599 (Liège: 1950); Galley N., De l'original à l'excentrique: l'émergence de l'individualité artistique au nord des Alpes, chapter 2, "La genèse d'une histoire de l'artiste nordique" (Fribourg: 2005) 99-155. For Hieronymus Cock cf. van Grieken J. - Luijten G. - van der Stock J., Hieronymus Cock - De renaissance in prent, exh. cat. Leuven - Paris - Brussels: 2013).

66 Printed at The Hague.

67 Antwerp, Philip Galle: 1572. Cf. also Philip Galle's Imagines L doctorum virorum qui bene de studiis literarum meruere (Antwerp, Philip Galle and Franciscus Raphelengius: 1587).

68 For Perna, cf. Rotondò A., Pietro Perna e la vita culturale e religiosa di Basilea fra il 1570 e il 1580, Studi e ricerche di storia ereticale italiana del Cinquecento. (Turin: 1974); Welti M.E., Kleine Geschichte der italienischen Reformation (Gütersloh: 1985) 25-135 (= Schriften des Vereins für Reformationsgeschichte, vol. 193); Perini L., La vita e i tempi di Pietro Perna (Rome: 2002), with a numbered catalogue of the 430 editions printed by Perna, 1549-1582.

69 Giovio Paolo, Elogia virorum bellica virtute illustrium (Basel, Petrus Perna: 1575); idem, Elogia virorum literis illustrium (Basel, Petrus Perna: 1575). Cf. Rave, "Paolo Giovio und die Bildnisvitenbücher" (119-154) 150-153. 


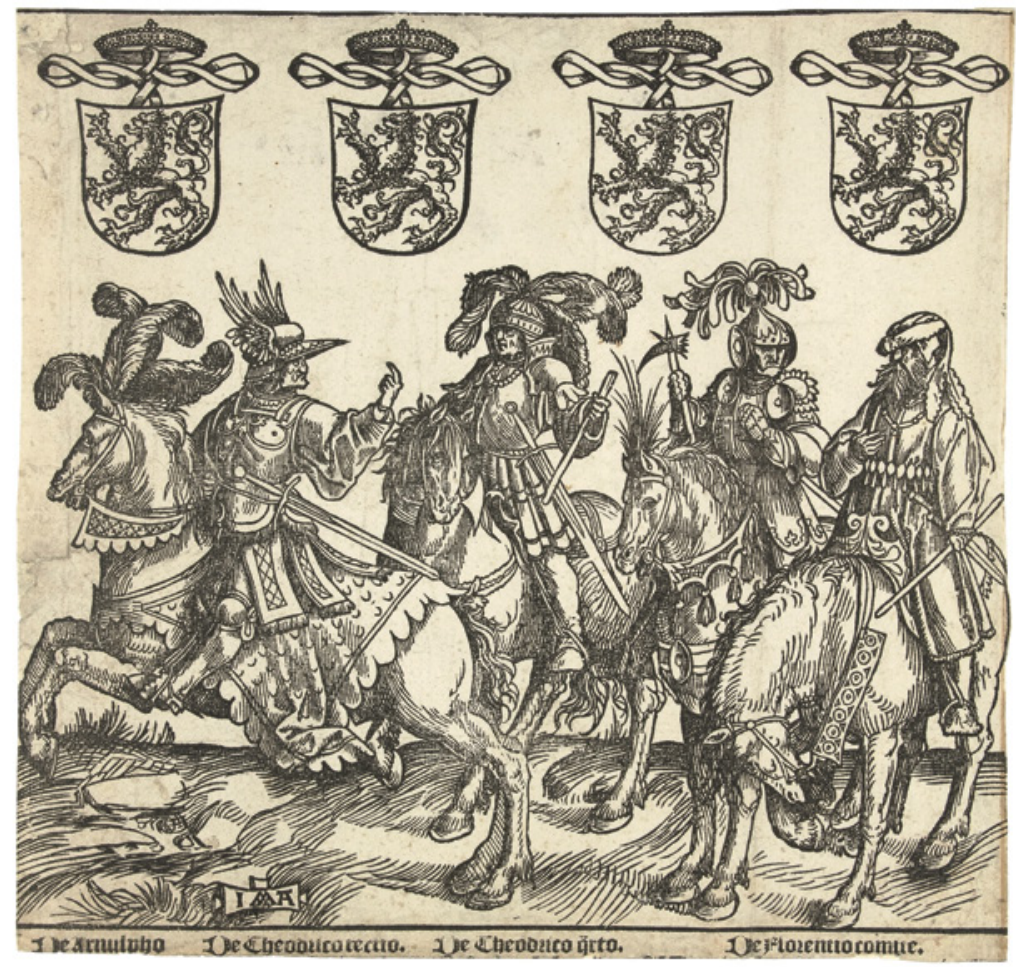

FIGURE 10.18 Jacob Cornelisz. van Oostsanen, The counts of Holland, from left to right: Count Aernout I, Dirk III, Dirk IV, and Floris I IMAGE (C) RIJKSMUSEUM, AMSTERDAM

honour on the one hand the humanists who had left all previously-published works far behind them, on the other hand the famous kings and military leaders. It is notable that the series of the Counts of Holland was one of the earliestprinted illustrated biographical series. As far back as 1518, Amsterdam printer Doen Pieterz. had come out with a series of the Counts of Holland coupled with a French translation of the Dutch poems found on the Haarlem panels. ${ }^{70}$ The woodcuts were by Jakob Cornelisz. van Oostzanen [Figs. 10.18 and 10.19]. ${ }^{71}$ Doen Pieterz.'s publication of the portraits of the counts appears to have been a

70 Cf. van Anrooij, De Haarlemse gravenportretten 159. The text of the French translations was published by van Anrooij, ibidem, 161-197.

71 For the wood carvings, see Beelaerts van Blokland W.A., "Stamreeksen in beeld. De graven van Holland en de heeren van Brederode door Jacob Cornelisz. van Oostzanen en Cornelis Anthonisz.", De Nederlandse leeuw 51 (1933) 202-207; Nijhoff W., "De graven van Holland, houtsneden van Jacob Cornelisz, met Franse tekst. Amsterdam, Doen Pieterszoon, 1518", Het boek 25 (1938-1939) 51-52; Ward J.P., "Hadrianus Barlandus and a 


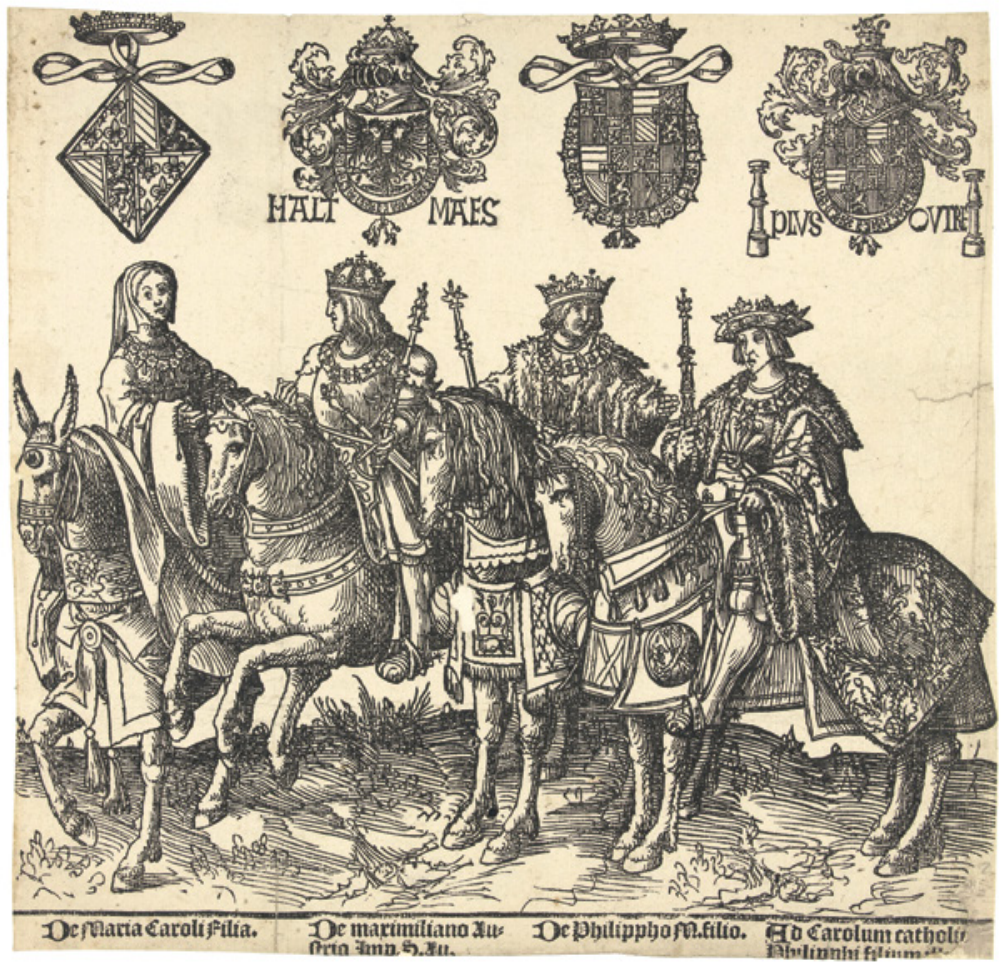

FIGURE 10.19 Jacob Cornelisz. van Oostsanen, The counts of Holland, from left to right: Maria of Burgundy, Maximilian I, Philip the Handsome, and Charles $\mathrm{v}$

IMAGE (C) RIJKSMUSEUM, AMSTERDAM

success: shortly thereafter, he reissued the series, this time with the Latin texts of the humanist historian Hadrianus Barlandus, whose Principes Hollandiae had just appeared in print in Antwerp. ${ }^{72}$

Catalogue of the Counts and Countesses of Holland Published at Amsterdam by Doen Pietersz", Humanistica Lovaniensia 55 (2006) 71-110.

72 Barlandus Hadrianus, De Hollandiae principibus (Antwerp, Johannes Theobaldus: July 1519), followed very quickly by a second edition in idem, Libelli tres [...] uno principum Hollandiae, altero episcoporum insignis ecclesiae Traiectensis, tercio res gestae continentur invictissimi principis Caroli Burgundiae ducis [...] (Antwerp, Michael Hillenius: January 1520). For Doen Pieterz's publication with the title Catalogus comitum Hollandiae (Amsterdam: 1519/ 1520), see Ward, "Hadrianus Barlandus". Doen Pieterz's publication is apparently not mentioned in Haitsma Mulier - van der Lem (eds.), Repertorium. Ward, "Hadrianus Barlandus", especially 75, has identified the author of the texts accompanying Doen Pieterz's publication as Hadrianus Barlandus. 


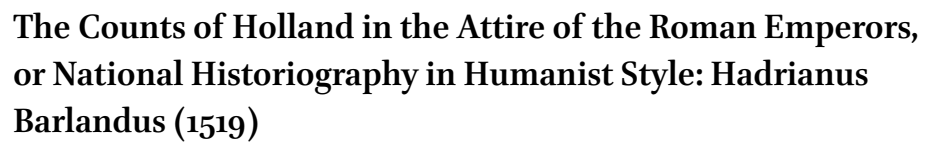

Another series of the Counts of Holland which likewise was made from a Habsburg perspective was that of the humanist Hadrianus Barlandus (14861538), born in Baarland on the Zeeland island of Zuid-Beveland, who was a disciple and friend of Erasmus. ${ }^{73}$ Barlandus had studied at the University of Louvain and took holy orders in 1515 . In 1518, he was appointed a professor at the Collegium Trilingue, which had just been founded at Erasmus's initiative. This new humanist institute of education aimed to teach Latin, Ancient Greek and Biblical Hebrew in the most accomplished manner. Barlandus already had a good number of philological publications to his name by this time, including commentaries on classical authors such as Pliny the Younger, paraphrases of the exempla of Valerius Maximus, and a work on the scholarly achievements of some Roman Caesars. ${ }^{74}$ In early 1519, however, he resolved to devote himself solely to the writing of history. His first historiographical work was Principes Hollandiae (Counts of Holland). The first edition appeared at Antwerp in 1519, rapidly followed by a second (early 1520$) ;{ }^{75}$ neither was illustrated. Later editions were, however, accompanied by portraits of the Counts: the first illustrated edition came out in 1520 (1519?), with woodcuts of Jakob Cornelisz. van Oostzanen, by Amsterdam printer Doen Pieterz. ${ }^{76}$ Later, Barlandus's Principes Hollandiae was published with Philip Galle's engravings by Christopher Plantin $(1584), 77$ with Jost Amman's woodcuts by Johannes Wechel (for Sigmund

73 For Barlandus, see Daxhelet E., Adrien Barlandus, humaniste belge, 1486-1538. Sa vie, son oeuvre, sa personnalité, Humanistica Lovaniensia 6 (Leuven: 1938); Bietenholz P.G. et alii (eds.), Contemporaries of Erasmus. A biographical register of the Renaissance and Reformation, 3 vols. (Toronto: 1985-1987) 95-96.

74 Barlandus Hadrianus, De literatis urbis Romae principibus opusculum (Louvain, [n.p.]: 1515); also in idem, Historica (Cologne, Bernardus Gualtherus: 1603) 1-13. Cf. Haitsma Mulier - van der Lem (eds.), Repertorium 21, no. 27 a.

75 Barlandus Hadrianus, De Hollandiae principibus (Antwerp, Johannes Theobaldus: July 1519); idem, Libelli tres [...] uno principum Hollandiae, altero episcoporum insignis ecclesiae Traiectensis, tercio res gestae continentur invictissimi principis Caroli Burgundiae ducis [...] (Antwerp, Michael Hillenius: January 1520). For both publications cf. Haitsma Mulier van der Lem (eds.), Repertorium 21, no. 27 b. Cf. also: http://www.dutchrevolt.leiden.edu/ dutch/geschiedschrijvers/Pages/Barlandus.aspx.

$7^{6}$ For this series, see Ward, "Hadrianus Barlandus".

77 Barlandus Hadrianus, Hollandiae Comitum historia et icones. Cum selectis scholis ad lectoris usum [...] (Christopher Plantin, Leiden: 1584). 
Feyerabend) in $1585,{ }^{78}$ with new woodcuts made by an unknown artist by Petrus Scriverius in 1609 (repeated in 1611), and, by the same Scriverius, with the engravings made by Cornelis Visscher in $1650 .{ }^{79}$

Barlandus's new Principes Hollandiae was introduced by an epigram on the title page. In it, the poet, his fellow humanist Hadrianus Cordatus, identifies Barlandus with the Roman historian Suetonius, the celebrated author of twelve biographies of Roman Caesars (De vita Caesarum, covering the emperors from Augustus to Domitian):

Romanos proceres scriptor Tranquillus adumbrans

Magna immortales reddidit arte viros.

Non secus Hollandos Comites Barlandus ab umbris

Evocat ad lucem candidore via.

Tranquillo Italia et Barlando Hollandia debet:

Hic Batavos, Latios colligit ille duces.

Suetonius Tranquillus immortalised the outstanding men of Rome / through his artfully drawn portraits. / Similarly, Barland now brings to life the Counts of Holland, summoning them / from the underworld to the bright light in a remarkably splendid way. / Italy is obliged to Suetonius Tranquillus, Holland to Barland: / because the latter has collected a series of Batavian rulers, as the former did of the rulers of Latium.

Just as Suetonius immortalised the Roman emperors in his biographies, so Barlandus intended to give the Counts of Holland an immortal memory through his work. It is important to note that Suetonius's Lives of the Caesars was a highly influential work in the Early Modern era, particularly in the visual arts. Plenty of series of portraits of the Caesars were made in the period, in paintings and sculptures, woodcuts and engravings, both in Italy and in transalpine lands. Their portraits were erected or hung in the residences and palazzi of noblemen and cardinals. It was no coincidence that most of these series consisted of exactly twelve Caesars: the same twelve whose biographies Suetonius had written. The fact that the Counts of Holland are equated with the Roman Caesars on the title page of Barlandus's work signified, of course, a huge boost to the cachet of the local rulers of this province.

78 Barlandus Hadrianus, Hollandiae Comitum historia et icones [...] (Frankfurt am Main, Johannes Wechel for Sigmund Feyerabend: 1585). 
Barlandus profiles himself in the letter of dedication of his book as a very serious historian. As he puts it, he has taken great pains to bring this work to fruition: in particular, he claims to have carried out an exhaustive survey of the sources, and that, for his research, he visited 'many different libraries'. This is a remarkable statement because this was not customary practice among Early Modern historiographers. What Barlandus reports about his acute study of the sources might also indicate an attempt to lend credibility to his identification with Suetonius, because Suetonius was well-known for having been an inveterate archivist with an enormous wealth of documentation at his disposal. However, as a matter of fact, Barlandus lagged far behind his Roman precursor: Suetonius had eagerly researched the imperial archive and the entire private correspondence of the Julio-Claudian emperors, whereas Barlandus had at most looked into a few chronicles. This is reflected in the respective quantities of information: while Suetonius's biographies of the Caesars average 25 pages in length, Barlandus's biography of each count runs to just a single page, and in some cases merely a few lines.

This could be seen as a serious shortcoming, but that is only one way of looking at the matter. The main reason for the author's brevity is his particular purpose. Barlandus sought to make his Counts of Holland primarily an easily accessible compendium, setting out the historically-reliable facts in modern, humanist Latin. This is why each count has only a short chapter about him. In a sense, the function of the individual chapters in fact resembles those of the captions for the Haarlem paintings of the Counts of Holland: the information on each count was required to be succinct, pithy and taken in at a glance. This historiographical aim determined Barlandus's methodology: what he dug up in the rambling sentences of prolix chronicles, he produced as short, carefullyworded and highly-polished humanist Latin, in a style meeting the demanding requirements of classical Roman historiography. Besides producing good style, a serious historian was also required to maintain a critical aloofness as regards his content. These were, after all, details handed down to the present day from the past; a serious historian must not give a new lease of life to any old fancies. In the sources which Barlandus consulted, the Dutch chronicles, there was no shortage of such nonsense, in his view: scarcely creditable tales, fables and long-winded descriptions containing details that could not square or that were irrelevant to history. In Barlandus's view, the writing of serious, worthy history was a matter of reducing, summarising and sifting sources so as to retain a trustworthy essence of historical truth. Only by means of this method could the aim be attained of integrating the Counts of Holland into the canon of classical Latin literature. 
With his Principes Hollandiae, Barlandus presented a kind of national historiography in a fresh, humanist style. The Counts now emerged in new, classical garb: that of Roman rulers and Caesars. This is apparent even in the title of the work: dispensing with the Latin noun customarily used for the rank of count in his day, comes, Barlandus uses the classical noun princeps, which in Roman antiquity was used for none less than the emperor himself. The wording Barlandus applies in his Principes Hollandiae often smacks of the Roman historians of the Silver Latin period, such as Valerius Maximus and Suetonius. For his description of Godfrey the Hunchback, for example, he refers to a detail of the description of the body of Galba Suetonius had inserted in his Lives of the Caesars ('a bulge of flesh had grown out of his body'). ${ }^{80}$ This kind of presentation gives Godfrey something of the air of a Roman Caesar, or even identifies him with Emperor Galba, who, like Godfrey, enjoyed only an extremely brief reign of less than a year. ${ }^{81}$

Barlandus's new-fangled writing of national history was also motivated by the main target audience he had in mind: the élite of the Province of Holland, particularly young patricians and noblemen. With this in mind, he dedicated his book to three young noblemen of Holland who had studied at Louvain: Joris and Philip of Egmond and Maximilian of IJsselstijn. One of Barlandus's aims with the work was pedagogical: by restricting his scope to facts and feats, and by editing out any morally-questionable conduct by his subjects, he expected that his historical work would contribute to the moral education of élite youth such as Joris and Philip of Egmond. The fact that the solid value of classical Roman historiography radiated from every page was meant to have a positive effect on the young men's identity formation. They could draw upon it to develop a sense of national (or regional) pride, since they were enabled now to partake in a national history of eternal value, just as classical Roman history had.

Besides addressing three young noblemen, Barlandus also dedicated his Principes Hollandiae to the reigning Count of Holland, Prince Charles of Habsburg, later Emperor Charles v [Fig. 10.20]. Rather than having a chapter about him in the book like his predecessor counts, Charles is given a dedicatory letter, in which Barlandus expresses the high hopes which society had for young Charles. Doubtless, he writes, Charles will exceed his exemplary forefathers

$80 \quad$ Suetonius, De vita Caesarum, "Galba" 21: 'excreverat etiam in dexteriore latere eius caro [...]'; Barlandus, Principes Hollandiae, ch. on "Godefridus": “[...] gibbosus dictus, quod grandis ei pectore gibbus excreverat".

81 Galba was Emperor only from June 8, AD 68 to January 15, AD 69; Godfrey the Hunchback had expelled Count Dirk v in 1075 and was murdered as shortly thereafter as February 27, 1076. 


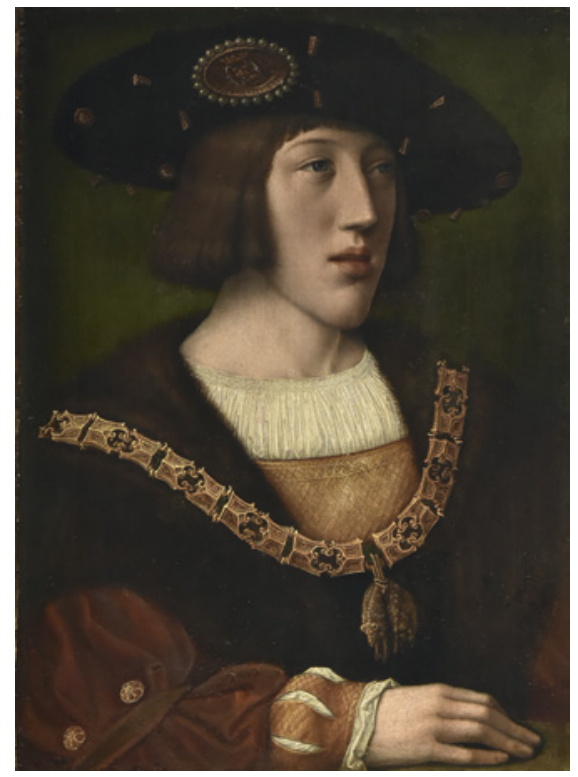

FIGURE 10.20

Bernard of Orley, Portrait of Prince Charles. Oil on panel, $37 \times 27 \mathrm{~cm}$

IMAGE (C) BOURG-EN-PRESSE, MUSÉE DE BROU

in virtue: Philip the Good (1428/33-1467) in piety (pietate), Charles the Bold (1467-1477), after whom he was named, in martial valour (bellica virtute); great Maximilian of Habsburg in mercy and clemency (clementia); and, finally, his own father, Philip the Handsome (1482-1506) in courtesy and suaveness (comitate facilitateque). This letter - in combination with the preceding chapters on the Burgundian and Habsburg Counts of Holland - was intended to function as a mirror of princes: Barlandus is holding up to Charles the ideal qualities of a prince and the high expectations there are for his coming reign, and at the same time is assuring him that he will be able to live up to those expectations, since he has it within him, as it were, due to having inherited the fine qualities of his illustrious forebears.

Charles's great importance is also seen in the genesis of the Principes Hollandiae. Barlandus started to compose the work shortly after the death of Emperor Maximilian (January 1519). ${ }^{82}$ The position of Holy Roman Emperor was now vacant, and the Louvain circles to which Barlandus belonged had fixed their hopes upon the election of Prince Charles. In this regard, the propagandistic function of the Principes Hollandiae hoves into view: the work contained the portrait gallery of the Habsburg Counts of Holland, and by being disseminated, it would boost Prince Charles's esteem. Charles's candidature for the imperial crown proved to be successful. Barlandus had completed his

82 As seen from Chapter 32 of the Principes Hollandiae, Barlandus expresses the hope that it might prove possible to secure a peaceful succession to Maximilian. 
Principes Hollandiae just before Charles was elected Holy Roman Emperor, on 28 June 1519: when the work appeared in print a few days later, Charles had already been proclaimed Emperor.

Barlandus's historiographical method had several repercussions for the early historical record of the Counts of Holland. For one thing, Barlandus entirely dispensed with the genealogical link to the Dukes of Aquitania. He no longer calls Dirk I 'Theodoricus of Aquitania' or 'the youngest son of the Duke of Aquitania'; nor, for him, does Aquitania's coat of arms have any connection with that of the Counts of Holland. Since Barlandus certainly will have encountered the genealogical connection with the House of Aquitania in his sources, we can be sure that this omission was due to his historical criticism. Barlandus regarded Dirk I's romantic origin story as a fairy tale, as also the assertion that he was of Trojan blood. Only for the sake of form does Barlandus mention Trojan blood at all, and he does so in such a manner as to distance himself from the claim: it is simply something 'as annals relate'.83 Moreover, Barlandus remains silent about the other infusions of Trojan blood into the counts' lineage, those supposedly derived from Dirk's wife 'Geva' (or 'Gena' or 'Gunna'), and from Arnout's wife, Lutgardis, who was regarded as daughter of a Byzantine emperor. Barlandus removed the fantastical Geva, the supposed daughter of Pepin I, and the supposed Byzantine (or even Trojan by origin, as Vosmeer would have it) Lutgardis from history. Evidently, he regarded them as belonging to the realm of fable. Besides, he would never have been minded to put down the Byzantine emperor as a 'Trojan'; his attitude was to put paid to all the fake Trojans. Barlandus was keen to present his counts as worthy figures, who while externally resembling knights, displayed a moral attitude very much like the one of the heroes of ancient Roman history.

\section{6 The Counts as Figureheads of the Revolt: Plantin's Edition of Barlandus's Biographical Series (1584)}

In 1583, the renowned Antwerp printer Christopher Plantin, who had brought out many books in the service of Philip II of Spain (including, as recently as 1578, Vosmeer's Principes Hollandiae), moved his business to Leiden. The States of Holland had recently awarded him the tender as printer for the newly-founded (1575) University of Leiden. Remarkably, the first work Plantin published in Latin was none other than the series of Counts of Holland, Hollandiae comitum historia et icones. Plantin dedicated this work to the new political authority,

83 Ibidem, fol. Aiii r: ‘[...] Theoderico cuidam, Troiani sanguinis viro, ut annales tradunt'. 
the States of Holland. ${ }^{84}$ This was a conscious choice, a political statement on his part. Even on the title page [Fig. 10.21], Plantin makes great play of his ties with the rebel province: within the secure garden of Holland sits Hollandia personified. She is not, as she is in Vosmeer's 1578 series, holding a palm frond of victory in her hand [cf. Fig. 10.2]. Instead, she bears four arms in her hands, in a highly revealing combination: the shields are of William the Silent, leader of the rebel faction; of the Province of Holland (the lion); of the City of Leiden (the keys); and finally of the University of Leiden (Pallas Athene). His personal emblem as printer, the golden compasses, Plantin symbolically places at the garden's access gate. This represents his pledge to set his printing press to work in the interests of the Province of Holland and to give his all in her defence.

We shall not be considering here what Plantin's actual political and religious convictions were; in that regard, this celebrated publisher and printer was rather a chameleon. His considerable nous consistently allowed him to have it both ways: he published for the Spanish king and the Catholics as well as for the rebels and Calvinists. What he grasped very well was that in the rebel provinces, a series on the Counts of Holland might be a highly useful asset, even if the texts had been written by a Habsburg loyalist, and even a Catholic, as Barlandus. Plantin saw that a Counts of Holland series could do service in his own day as a source for "national" or regional identity. This would give rise to a new national pride, one which could enmesh with the disdain or hatred generally felt towards the Spanish "tyrant". With his Counts of Holland series, Plantin was evidently meeting the requirements of his new employers' political agenda. As he sets out in his dedication, he wished this to be a work suited to enhancing the respectability of the States of Holland. ${ }^{85}$ The counts are presented in it as role models and as exempla historica for that political assembly. It was, then, by design that the series of portraits of the counts were reproduced in large numbers between 1584 and 1650, and that they were used as an early national portrait gallery.

It is understandable that Plantin opted not to print Vosmeer's poems to accompany Galle's portraits; the authorities in Holland would have taken this as effrontery. It was thus an obvious choice to use Hadrianus Barlandus's text, which was in various aspects neutral and which was compact and compendium-like in form. A further benefit of Barlandus's text was that it did not mention Philip II (as he had not yet been born at the time of its composition).

\footnotetext{
84 See the letter of dedication: "Amplissimis prudentissimisque Hollandiae provinciae Ordinibus Christophorus Plantinus S.D.", in Barlandus Hadrianus, Hollandiae comitum historia et icones [...] (Leiden, Christopher Plantin: 1584), fol. *2r $-\mathrm{v}$.

85 Ibidem, fol. *2r.
} 


\section{Hadriani Barlandi HO L L A N D I AE COMITVM HISTORIA \\ E T I C O N E S:}

Cum Jelectis fcholis ad Lectoris lacem.

Eiufdem Barlandi

CAROLI BVRGVNDIA DVCIS VITA.

I T E M

VLTRAIECTENSIVM EPISCO:

P O R V M C A T A L O G V S E T RES GESTA:

Eiufdem argumenti Libellus GERARDO NOVIOMAGO auctore.

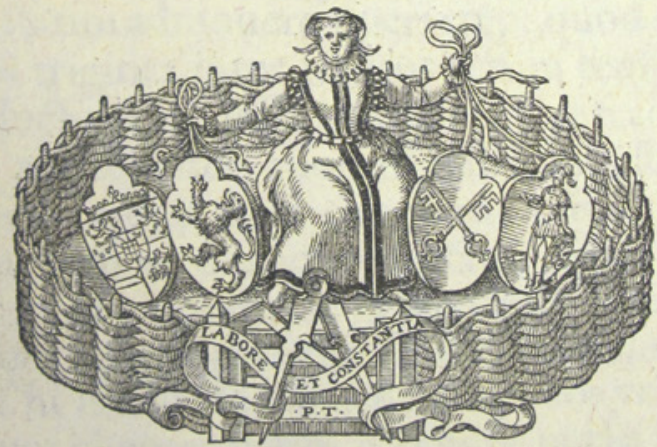

LVGDVNI BATAVORV M;

Ex officina Chriftophori Plantini. cIj. Iว. LXXXIV.

FIGURE 10.21 Hadrianus Barlandus, Hollandiae comitum historia et icones (Leiden, Christopher Plantin: 1984), title page IMAGE (C) UTRECHT UNIVERSITY LIBRARY 
To the Hollanders, praise of Philip would have been like a red rag to a bull. For this reason, he was not given a chapter in Plantin's 1584 edition, although Plantin did have - precisely because of the Vosmeer edition - an image to hand of this Spanish king in copperplate. ${ }^{86}$

It is worth noting that Plantin amended Barlandus's text at various points. He evidently found Barlandus's reticence to report the Aquitanian and Trojan roots of the Counts of Holland regrettable, so he (or one of his assistants) added to Barlandus's text that Dirk I was the son of an 'Aquitanian'! Even more remarkably, the highly elusive, unhistorical dark horse Sigisbertus crops up anew. In Plantin's text of Barlandus, Dirk I is presented as 'the son of Sigisbertus of Aquitania, a man of Trojan blood'. This text appears alongside Galle's imposing portrait of Dirk I [Fig. 10.4]. It is clear that in the political context of the Dutch Revolt, the Trojans had by no means shuffled off the stage as forefathers of the Counts of Holland. Seemingly, a link to the extreme antiquity of Troy was considered to be particularly valuable in this time of such felt need of legitimacy in the rebel province.

Plantin's fresh grafting-in of 'Sigisbertus of Aquitania' into the family tree, thereby reviving the Trojans and Aquitanians as progenitors of the Counts of Holland, would prove to have major consequences later on: through this addition, 'Sigisbertus of Aquitania' and the Trojans even outlived the Eighty Years' War and the Peace of Münster (1648). Largely responsible for this survival was the Leiden antiquarian Petrus Scriverius, who from 1609 onwards published several series of portraits of the Counts of Holland based on Plantin's edition of 1584, using Plantin's 'take' on the text of Barlandus's Principes Hollandiae. Due to this, the supposed Trojan and Aquitanian father of Dirk I still featured in the portrait gallery Scriverius published at Haarlem in 1650, which displayed the beautiful new engravings of Cornelisz. Visscher [Fig. 10.22].$^{87}$ The poem under the portrait asserts that Dirk I boasted Trojan blood. ${ }^{88}$

86 Moreover, this Leiden version of the counts omits John III, Duke of Bavaria (the 28th Count of Holland), who was bishop-elect of Liège and the rival of Jacqueline of Hainaut (alias Jacoba, Countess of Bavaria). It would seem that this episcopal usurper of the county was no longer counted worthy of ornamenting the history of Holland.

87 Principes Hollandiae et Westphrisiae (Haarlem, Pieter Soutman: 1650).

88 It is a curious detail that another important historian of the Dutch Republic, Hugo Grotius, acknowledged even in 1610 the fantastical marriage of Count Arnout I with a daughter of the Byzantine emperor, and moreover the fake that Arnout's wife was the sister of the Byzantine princess who married the German Emperor (i.e. Theophanou). Cf. Grotius Hugo, De antiquitate Reipublicae Batavicae, chapter v, 22: 'Arnulfo comitum tertio coniunx Constantinopolitani Imperatoris filia, cuius soror Germaniae Imperatori nupserat' - 'The third Count of Holland, Arnout, obtained as his consort the daughter of the Byzantine Emperor, whose sister married the German Emperor' (translation 


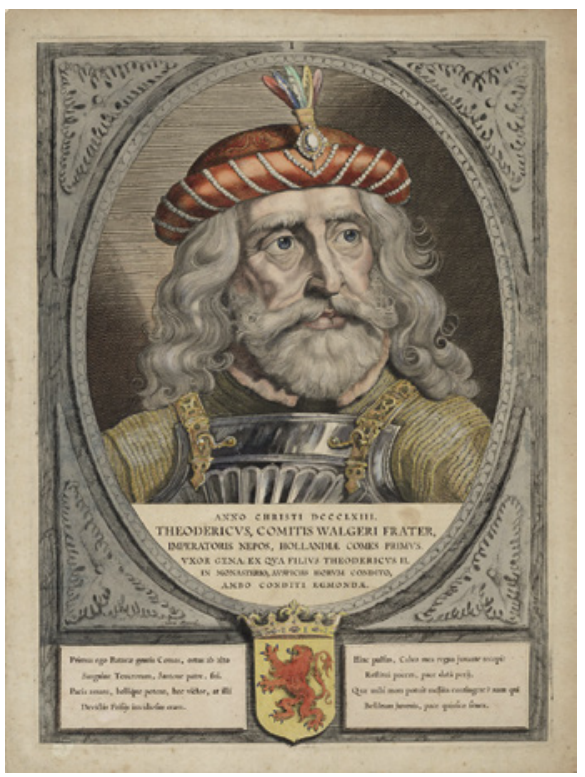

FIGURE 10.22

Dirk I, Count of Holland. Engraving by Cornelis Visscher II (1650), taken from: Petrus Scriverius, Principes Hollandiae [...] (Haarlem: 1650) IMAGE (C) RIJKSMUSEUM, AMSTERDAM

\section{The Counts in the National Gallery of Honour: Georgius Benedicti Wertelos's Epitaphs and Petrus Scriverius's Series}

The Calvinist theologian and Neo-Latin poet Georgius Benedicti Wertelos (1563-1588) was inspired by Plantin's illustrated edition of the Counts of Holland, with its wonderful portraits by Philip Galle. Benedicti was one of a group of promising young Dutch Neo-Latin poets who died far too young (another being Janus Dousa junior, the brilliant son of the curator of the University of Leiden). The Haarlem-born Benedicti was already composing Latin verse at a very tender age. At 22, he had his first poetry volumes published at Delft and Leiden: epigrams, epitaphs, laments, national songs and a heroic epos. However, he did not live to witness some of his poems see the light of day: they were published posthumously by the aforementioned Petrus Scriverius. ${ }^{89}$ A highly gifted boy, Benedicti went up to Leiden in 1577 to

mine). Cf. Grotius Hugo, Liber de antiquitate reipublicae Batavicae (Leiden, Franciscus Raphelengius: 1610); idem, The Antiquity of the Batavian Republic, ed. and transl. by Jan Waszink et al. (Assen: 2000) 96 (V, 22; in their commentary, the editors did not identify the sister mentioned by Grotius as Theophanou). The proliferation of this error is all the more remarkable, because Grotius's work was reprinted a couple of times.

89 Benedicti Georgius, Poemata posthuma, in quis Epigrammata, Epitaphia, Elegiae, ed. Petrus Scriverius (Leiden, Christoph Guyot: 1601). 


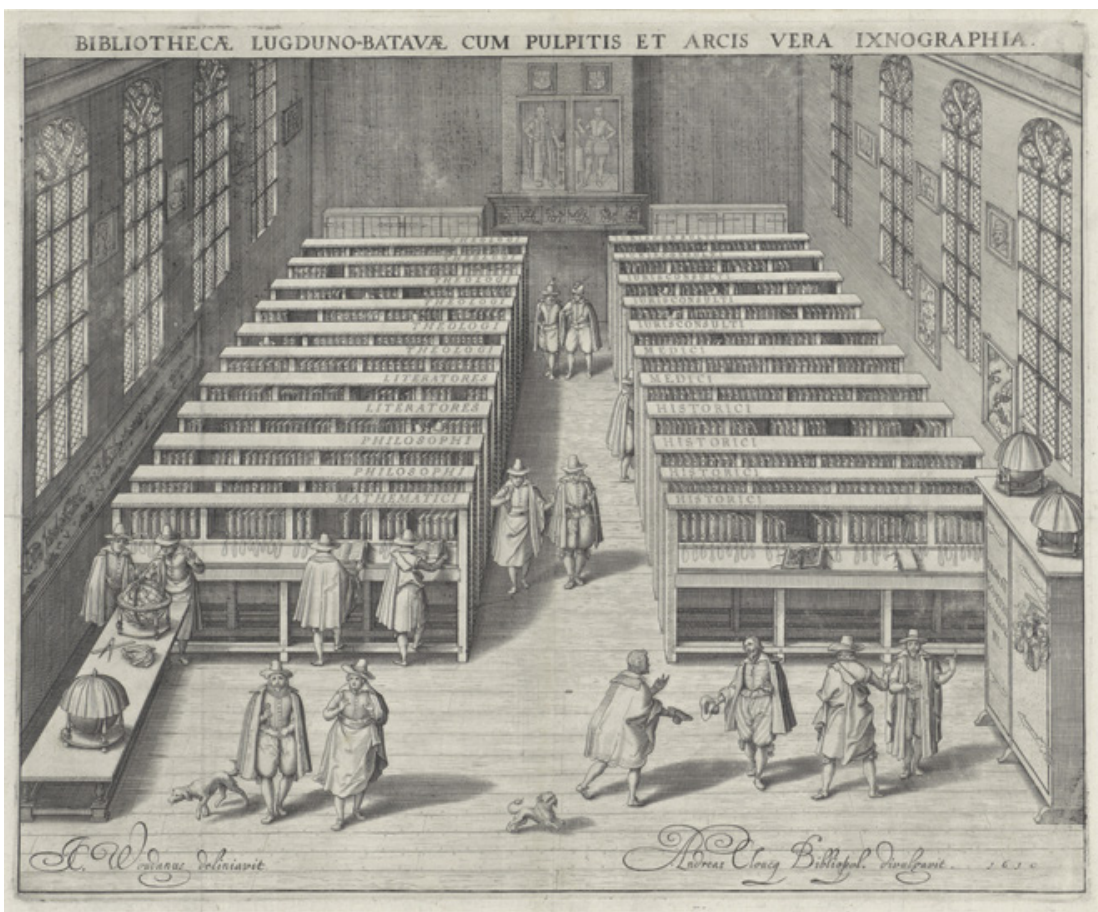

FIGURE 10.23 The university library of Leiden in 1610. Engraving by Willem Isaacsz. van Swanenburg, after Jan Cornelisz. van 't Woudt, $33 \times 40.3 \mathrm{~cm}$ IMAGE (C) RIJKSMUSEUM, AMSTERDAM

matriculate at the brand new university there [Fig. 10.23]. ${ }^{90}$ There, he roomed with Janus Gruterus (Jan de Gruytere, 1560-1627) and Petrus Bertius (Pieter de Bert, 1565-1629) - later to gain renown as excellent scholars - at the house of his mentor, the Hebrew professor Herman Reneker (Rennecherus, 1550after 1605), who had been appointed in 1575 at the personal recommandation of Prince William of Orange. In 1583, Benedicti continued his studies at Cambridge at the household seminary of the celebrated Protestant theologian William Whitaker (1548-1595). He found acceptance in the scholarly literary circle around the noble poet Sir Philip Sidney (1554-1586), Earl of Leicester; the Neo-Latin poet Janus Dousa junior was also in this coterie. These were the years in which Holland and the other northern provinces were eagerly seeking the support of the English crown and trying to persuade Queen Elizabeth I to

9o For Benedicti's biographical details, see de Schepper M., "Quem patrem patriae voluit/ (Deus): Georgius Benedicti Wertelos over Willem van Oranje”, Hermeneus 56 (1984) 244-245. 
take them on as her subjects. It was from this historical context that Sir Philip Sidney's mission to the Low Countries arose in 1586. In June of that year, Benedicti returned to the University of Leiden, but before long he had gone on to Heidelberg to round off his theological studies with the leading Calvinist theologian Franciscus Junius the Elder (later to become a professor at Leiden). Sidney's mission culminated in a hero's death, and Benedicti commemorated him in a series of Latin elegies and epitaphs. In 1588, Benedicti died unexpectedly at Heidelberg of a feverish infection.

Benedicti made no secret of his political sympathies. He was an adherent of the Dutch Revolt, of William of Orange, of Sir Philip Sidney and of the States of Holland. After William's assassination, he published a whole series of national poems: solemn Latin epitaphs and laments for 'the Father of the Fatherland' $(1585),{ }^{91}$ together with epigrams and, in the same year, a long-form national poem, an epos for William. It was at the very height of this rash of national poetry that Benedicti composed his series of poems on the Counts of Holland in 1586. He had them published in combination with his heroic epos on William of Orange. ${ }^{92}$ The poems on the counts were given the form of epitaphia, which in their celebration of national heroes resonated well with his epitaphs for William of Orange. Benedicti's series is an outstanding example of the way in which the Counts of Holland were invoked by a committed supporter of the Dutch Revolt, namely in a very direct manner indeed to help shape a new national or regional identity. The publication of the series is intimately connected with the assassination of William of Orange (1584). Its intended purpose was the honouring of national heroes and the fostering of national sentiment.

Benedicti's epitaphia on the Counts of Holland remained influential in the seventeenth century. They gained widespread recognition through their inclusion in internationally-renowned scholar Janus Gruterus's political history of the world, Chronicon Chronicorum politicum (Frankfurt, officiana Aubriana: 1614), ${ }^{93}$ and in his corpus of Dutch Neo-Latin poets, Deliciae poetarum Belgarum

91 Benedicti Georgius, Carmina quaedam in funere Guilielmi, Principis Arausionensis, Delphis parricidali manu occisi anno LXXXV [sic]. Additus est Epigrammatum libellus (Delft, Albertus Henricus: 1585).

92 Benedicti Georgius, De rebus gestis Principis Guilielmi comitis Nassovii, Principis Nassovii, libri duo. Item Epinicia, Epigrammata varia et Epitaphia comitum Hollandiae (Leiden, Joannes Paetsius: 1585). The epos has in modern times been republished, along with a Dutch translation, by the Leiden collegium classicum E.D.E.P.O.L.: De krijgsdaden van Willem van Oranje, Leiden, stichting dimensie, 1990 (A. de Best et al.). For the epos, see also Wijdeveld J., "Princeps Auriacus. De Prins van Oranje in het Neolatijnse epos en drama", Hermeneus 56 (1984) 234-243.

93 Gruterus Janus, Chronicum chronicorum politicum, in quo Imperatores, Reges, Duces, Principes, Marchiones etc. recensentur [...] (Frankfurt am Main, officiana Aubriana: 1614) 1007-1018. 
(Frankfurt am Main, officiana Aubriana: 1614); ${ }^{4}$ through their being printed in the influential The Republic of Holland and its Cities, Respublica Hollandiae et urbes, published by Johannes Maire (Leiden: 1630), which presented the new Republic to an international audience of readers; and also, and by no means least, through their inclusion in Leiden scholar Petrus Scriverius's Latin publications of the series of Counts of Holland in 1609, 1611 and 1650, enriched with gorgeous illustrations, first in woodcuts and later in engravings. ${ }^{95}$ By placing the poems as captions under these illustrations, Scriverius enhanced their status and impact. Benedicti had already conceived of these poems as national heroic poetry, but now, as poetic accompaniment to the counts' portraits, they formed part of a national gallery of honour, a sort of Dutch Valhalla.

Comparing Benedicti's poems with the texts on the Haarlem paintings and with Vosmeer's poems, one is struck by the far lesser interest which this young Leiden alumnus had in familial data, genealogical questions and precise dates. In the Haarlem series, each poem identifies the spouse(s) and children of the count in question; Vosmeer's epigrams name at least the consort. Yet even major events and breaches in the genealogical line meet with hardly any attention by Benedicti. For instance, he tacitly passes over the fact that Godfrey the Hunchback was not in the counts' bloodline, that he actually was the son of Godfrey the Bearded (997-1069) and had succeeded his father as Duke of Lower Lorraine (r. 1069-1076), that he conquered Holland as a foreign usurper, and that his reign did not last longer than a few months. Benedicti, only with the greatest of vagueness mentions that Godfrey had obtained 'his reign' (regna) in 'a bad manner', by force of arms. ${ }^{96}$ Far from rejecting Godfrey the Hunchback as a usurper, Benedicti lauds him for his 'justice' (iustitia) and for his having founded the splendid city of Delft, which 'would go on to obtain immortal fame. ${ }^{97}$ Benedicti is here referring to the Prinsenhof, from which the Prince of Orange governed the Northern Netherlands for a few years, and more particularly to the national tragedy, the assassination of that prince on 10 July 1584 [Fig. 10.24]. Benedicti even made his own contribution to 'Delft's

94 Gruterus Janus, Delitiae C poetarum Belgicorum, huius superiorisque aevi illustrium (Frankfurt a.M., Aubriana: 1614).

95 Scriverius Petrus, Illustrissimorum Hollandiae Zelandiaeque Comitum ac dominorum Frisiae Icones et historia, in: idem, Batavia illustrata [...] (Leiden, Ludovicus Elzevir: 1609; 1611) 1-184; idem, Principes Hollandiae et Westphrisiae (Haarlem, Pieter Soutman: 1650).

96 Cf. Benedicti, "Godifredus Gibbus", in Scriverius, Illustrissimorum Hollandiae Zelandiaeque Comitum ac dominorum Frisiae Icones et historia (1611), p. 20: 'Quid male parta meis, hospes, regna obiicis armis? / Quid poenam exposcis? [...]'.

97 Ibidem: 'Respice fundatas celebres me Principe Delphos. / Mox tangent ipsis sidera verticibus'. 


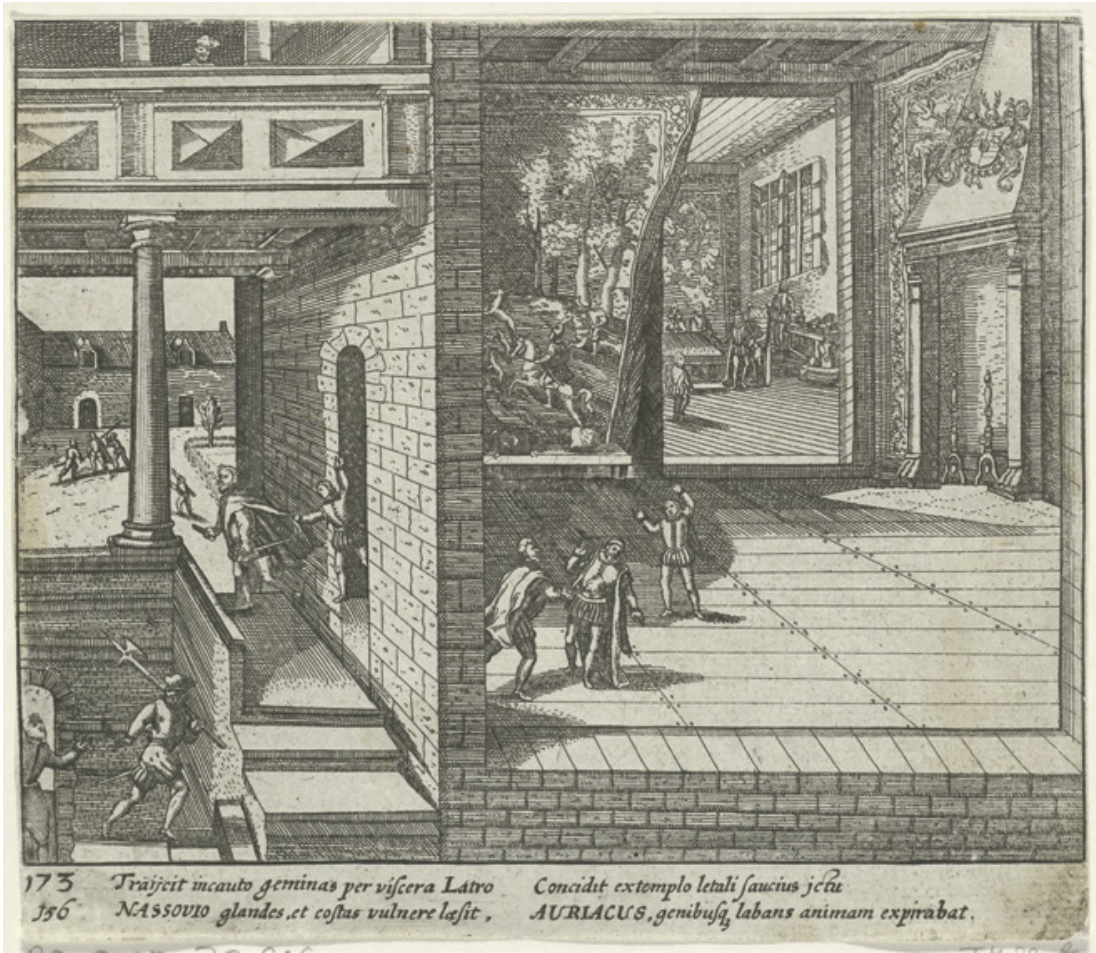

FIGURE 10.24 The assassination of William of Orange in 1584, in the Prinsenhof (Delft). Anonymous engraving after Frans Hogenberg, 1613-1615 IMAGE (C) RIJKSMUSEUM, AMSTERDAM

immortal fame' with his heroic epos on William of Orange, the 'Father of the Fatherland'.

While stressing the counts' virtues, Benedicti paid hardly any attention to courtly decorum. In the Haarlem paintings, the counts are introduced with great panache by a herald, delivering a suitable dose of such class. This creates a setting of courtly festivity: each count, as it were, makes his stately entrance in the festival hall and his arrival is solemnly declaimed by the herold to the court retainers. In Benedicti's poems, on the other hand, the counts introduce themselves in the first person: 'I am so and so [...]'; 'I accomplished such and such [...]'. In literary terms, Benedicti was revivifying the antique genre of the grave epitaph (epitaphium), a form which presumes that a passer-by has his attention arrested at the ruler's tomb by the deceased speaking to him. Perhaps the most famous is the inscription on the stele of the Spartan king Leonidas, who perished at the Battle of Thermopylae in $480 \mathrm{BC}$ while holding back the Persians. In his epigram, Leonidas tells the passer-by: 


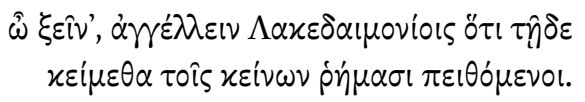

Stranger, tell them in Sparta that we rest in this place Because we were obedient to their order. ${ }^{98}$

Benedicti's epigrams are construed in the same way. He conceives of his texts as grave-inscriptions being reviewed by a visitor to the sepulchres. Indeed, he literally calls his poems epitaphia. Thus, the counts are addressing the visitor, or 'stranger'. Benedicti's Count William II, for example, tells of how he lost his life on the field of battle and asks the visitor: 'Why do you sigh, stranger? / You would be a fool not to wish for the same kind of death!.99 Floris IV is sure that the visitor will be wanting to hurry on past his tomb, and tells him that there is no need to admire his portrait; he can calmly walk on by. Should he be interested in Floris's heroic deeds, then he merely need ask anyone he comes across on the street to enumerate them. ${ }^{100}$ Countess Ada, on the other hand, makes a kind of gendered remark to the visitor: 'Stranger, just look what a woman can accomplish!!101

Benedicti presumes that the visitor will be reading his epitaphs through a moral lens. His Dirk IV shares that understanding, and asks exasperatedly: 'Traveller, why do you judge my career, my victories? / Be content with the fact that I was felled by the foe's hand'.102 Due to the atmosphere evoked by the epitaphs, it seems at times as though the 'visitor' were taking a tour around Egmond Abbey, scene of the graves of some of the comites Hollandiae. Poem 13 is a playful exception: the epigram for Floris III (1140-1190). To his surprise, the passer-by suddenly finds himself transported to Asia Minor, which was inacccessible to the Christian in Benedicti's day because it was in Turkish hands. Nevertheless, the visitor, now located in an oriental city, is peering at Floris III's grave, who pipes up: 'Visitor, why are you surprised to find a stranger's grave in Seleucus's city, / Chiselled marble on an unknown patch of earth? / Cease your wonderment [...].' 'Seleucus's city' is Antioch, the capital of the Seleucid

98 Meier M., Die Thermopylen - „Wanderer, kommst du nach Spa(rta)“, in Hölkeskamp H.J. Stein-Hölkeskamp E. (eds.):Erinnerungsorte der Antike. Die griechische Welt (Munich:2010) 98-113.

99 Ibidem, ch. XVIII, "Gulielmus II": 'Quid gemis, hospes? / Insanis, ni optes sic quoque posse mori'.

$100 \quad$ Ibidem, ch. XVII.

101 Ibidem, ch. XV: 'Foemina quid possit, cerne hospes!'.

102 Ibidem, ch. v: 'Quid vitam carpis, quid prelia gesta, Viator? / Sit satis hostili me periisse manu'. 


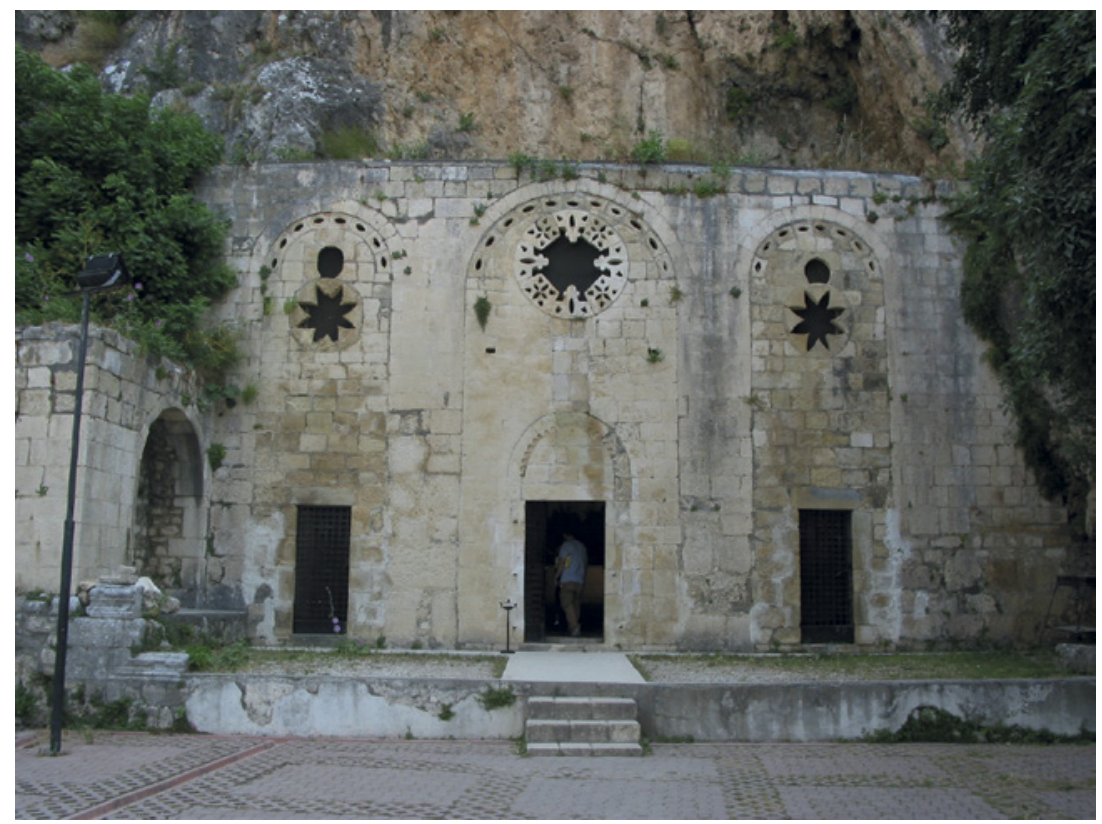

FIGURE 10.25 St Peter's Cathedral in Antakya (Antioch), Turkey IMAGE (C) VOLKAN HATTAN

Empire, the successor to Alexander the Great's oriental possessions. In the seventeenth century, Antioch had come to be known as Antakya by the Turks. Floris III died of plague there in 1190 while joining in the Third Crusade under Frederick I Barbarossa (1189-1192). In Benedicti's poetic presentation, we are standing in Antakya in front of the hero's grave of a brave Hollander. He was really buried there, in the cathedral of St Peter [Fig. 10.25], next to the altar, beside Emperor Frederick's own grave, who drowned during the crusade while crossing the Saleph river. ${ }^{103}$ In Scriverius' series of the Counts of Holland (1650), Benedicti's poem is accompanied by an impressive representation of Floris III as a fantastic oriental prince that wears a turban with a bunch of feathers [Fig. 10.26].

Through these poetic devices, Benedicti is equating the Counts of Holland with celebrated figures of classical antiquity: Leonidas, Pericles, Alexander the Great, Julius Caesar, Augustus, and the like. By his outline and judgement of their lives in his epigrams, he lends the counts a classical appearance. They become hardly distinguishable from the heroes of Ancient Greece and Rome. The concern here is to display their virtue and to reflect it in the moral

103 Cf. de Boer - Cordfunke, Graven van Holland 51. 


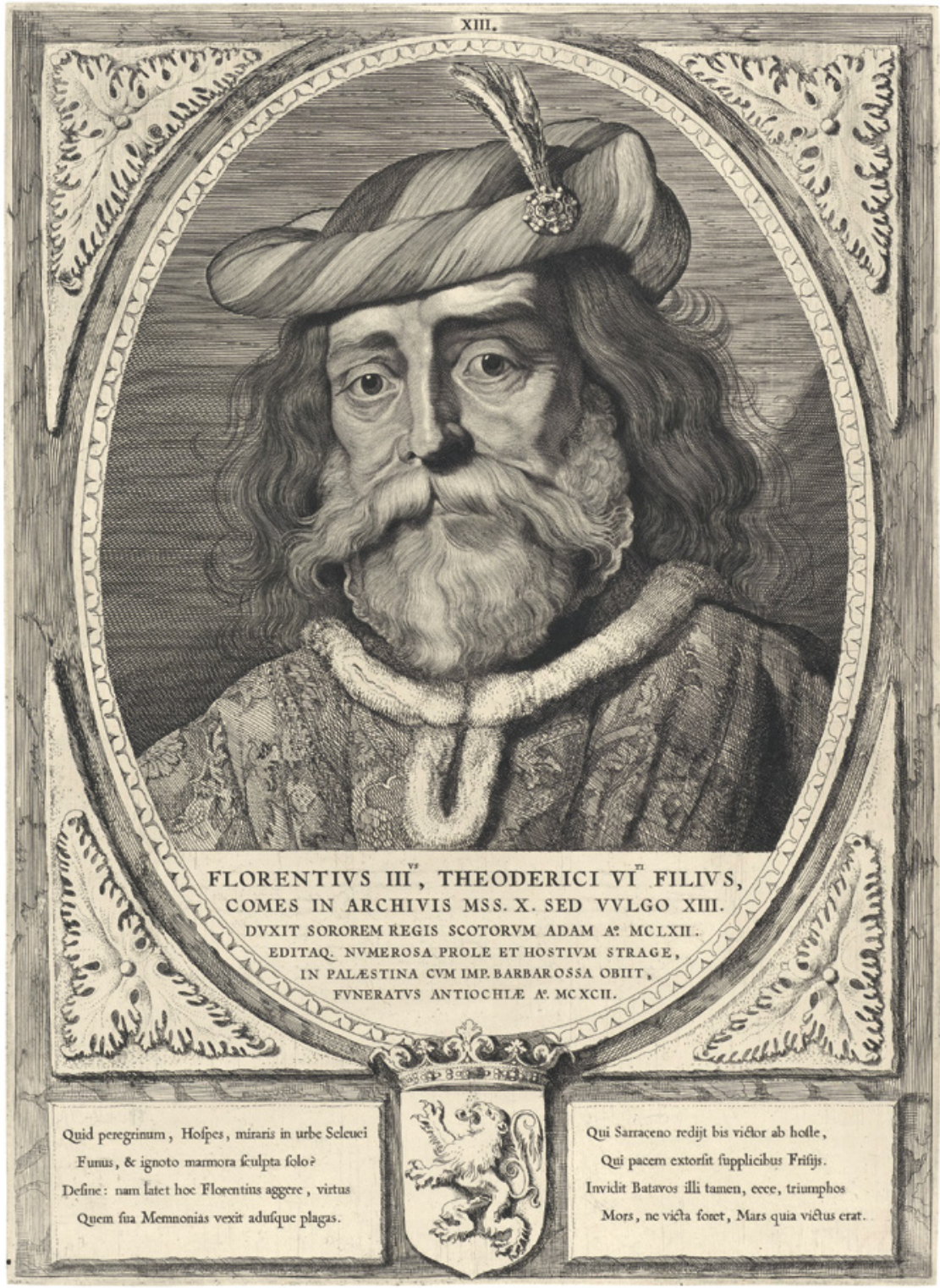

FIGURE 10.26 Floris II, Count of Holland. Engraving by Cornelis Visscher II (1650), taken from: Petrus Scriverius, Principes Hollandiae [...] (Haarlem: 1650) IMAGE (C) RIJKSMUSEUM, AMSTERDAM 
judgement of their descendants (posteritas). In fact, the literary visitor to the monuments of the counts embodies this progeny: he is the posteritas and it is he who judges. The epigram already cited demonstrates that King Leonidas fought the Persians like his namesake lion, to the last drop of his blood, out of pure duty. So the Counts of Holland had also often fought: Dirk III, for instance, 'defended his fathers' lion [the counts' arms, depicting a lion] as a lion would defend his lionly father and a father his own father'.104 Like Emperor Charles v, Dirk I was in principle striving for a peaceful settlement, but he was no slacker in warfare either: 'pacis amans bellique potens.' ${ }^{105}$

In his epigrammatic evaluations, Benedicti adopts the premise of classical and humanist historians: in their view, the chief aim of historiography is to hand on the deeds of famous men to following generations, to evaluate them, and, through the apportioning of praise and blame, to provide moral exempla for the generations to come. It is important that history be a school for life (historia vitae magistra) and that the reader be furnished with moral examples that teach him what to commit, or omit, in his life. References to posteritas (progeny), fama (fame), virtus (virtue) and exemplum (historical example) are found in almost every epigram.

In his moral evaluations, Benedicti likes using comparisons, such as ones between a given count and his predecessor or his successor (who was more virtuous, who more successful?) or his military opponents (who was morally in the right?); and comparisons between given virtues and vices, achievements and propensities. As well as judging the counts' own deeds, Benedicti also considers those of their foes, particularly the Frisians and the Bishop of Utrecht. The counts' episcopal opponents tend to come off badly. As regards the counts themselves, Benedicti is glad of opportunities to present moral dilemmas or considerations, such as: is it better to die in harness on the battlefield or to expire peacefully on one's own bed?106 Is a ruler demonstrating more virtue when he rapidly overruns a territory with few reverses, or when he retakes land that had been lost to the enemy? May a woman rule? Can a woman show virtue by exercising tasks of government? What is preferable: that an illegitimate prince hold sway for good ends, or that a legitimate prince fritters away or even abuses his power?

104 Benedicti, “Theodericus tertius", in Scriverius, Illustrissimorum Hollandiae Zelandiaeque Comitum ac dominorum Frisiae Icones et historia (1611), ch. IV, p. 10: Defendi patrium, patre non minor ipse, Leonem, / Proque parente parens, proque Leone Leo'.

105 Benedicti, “Theodericus primus", in ibidem, ch. I, p. 4: 'peace-loving, but mighty in war'.

106 E.g. ibidem, ch. I and III. 


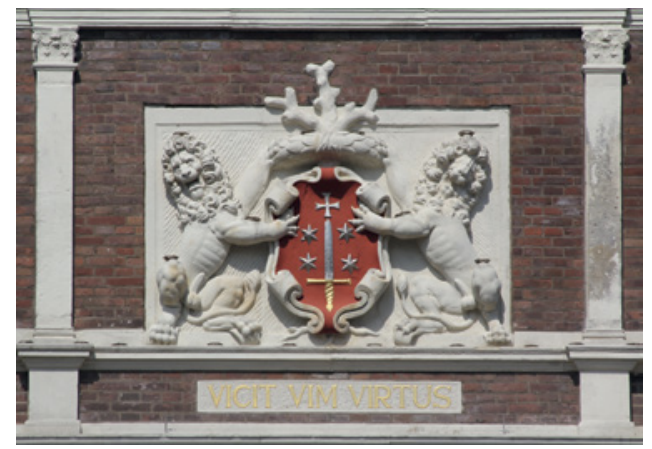

FIGURE 10.27

Coat of Arms of the City of Haarlem

(Town hall, Grote Vierschaar)

Moral excellence (virtus) is indeed the central theme of Benedicti's poems, in both a general and a specific sense. The way in which he expresses his moral meditations is often emphatic and solemn, as would have befitted the Romans of old, such as Cato the Younger, who defended the Roman Republic to his dying breath. 'Vicit vim virtus' ('Virtue overcomes violence'), as Benedicti proclaims in his tenth epigram, could just as well have been a phrase uttered by Cato. Wittily, Benedicti is here citing the motto of his native city of Haarlem, VICIT VIM VIRTUS [Fig. 10.27]. Here, Benedicti is engaging in literary play with his the expectations of his readers, who certainly knew the city motto. Haarlem's motto is a boast about the deeds of the city's sons, particularly in regard to a Haarlem continent under the command of the Count of Holland, William I, who had conquered the Egyptian city of Damietta in 1218, during the Fifth Crusade. ${ }^{107}$

In his poems, Benedicti uses the motto 'vicit vim virtus' in the epigram for Count Dirk v, who had laboured hard to reconquer his possessions after he had been expelled from the county of Holland by Godfrey the Hunchback (in 1075). ${ }^{108}$ Dirk v's virtue was characterised by his persistence. In other regards, too, Benedicti ascribes particular virtues to given counts. Dirk I excelled in valour and peaceableness; Arnout I in martial valour alone - being the first Count of Holland to die on the battlefield; Dirk III distinguished himself by his sense of filial duty, perseverance and courage; Godfrey the Hunchback and Floris II by their sense of justice (iustitia), and the latter was also dutiful,

107 Cf. van Anrooij W., "Middeleeuwse sporen van de Haarlemse Damiate-legende", in Grootes E.K. (ed.), Haarlems Helicon. Literatuur en toneel te Haarlem, before 1800 (Hilversum: 1993) 11-25.

108 Benedicti, "Theodericus quintus", in Scriverius, Illustrissimorum Hollandiae Zelandiaeque Comitum ac dominorum Frisiae Icones et historia (1611), ch. X, p. 22. 
peaceable and pious. Thus, the counts become exemplary embodiments of individual virtues.

It is evident that the old counts with their virtues, and particularly their military virtues, were intended to serve as examples to the elite of the rebel province. With his epitaphia, Benedicti created a national heroes' gallery. The epitaphia on the counts were of no less importance for the formation of Holland's new identity than Benedicti's epitaphia on William of Orange or his epos on the same hero. The counts are presented as heroes of the Fatherland and are connected with both the ancient and the modern race of the 'Batavians'.

In fact, the great importance of the Counts of Holland as sources of national identity does not imply that the creator of the series necessarily had to acknowledge the actual legitimacy of their rule. This is seen plainly from Benedicti's poem alongside the portrait of Philip II (as Count Philip III of Holland), the prince whom the States-General had abjured in 1581. In this epigram, Philip considers himself a loser: his power and military might did not prevail against the Batavians. The Batavians, the poem recounts, were not impressed by his swagger and not persuaded to desist from their warfare against the king. Philip is made to reflect that although he still bears the title of thirty-sixth Count of Holland, he is no longer recognised. He himself admits as much by being made to say that the the Hollanders have become a 'free people', one 'that will never again recognise monarchic rulers' ('libera gens, nullos umquam admissura monarchas'). ${ }^{109}$ Naturally, this does not please him, but the very fact that he acknowledges it is appropriated to legitimise the rebels. The Hollanders' love of freedom is in "the nature of their people" - in their genes, one would say today - and none will be able to affect that, the epigram proclaims. A true Batavian will not brook of any king or emperor lording it over him. This largely concurs with the image of the ancient Batavians as sketched by antiquarians and writers in the sixteenth and seventeenth centuries.

What, though, of the Trojans? Given that Benedicti had little interest in genealogy, family questions and courtly customs, instead paring almost everything down to moral issues, one might expect that he would leave the Trojans aside. It is, in a way, surprising that he in fact does not: he reports that Dirk I 'sprang from the Trojans' noble blood' ('ortus ab alto / Sanguine Teucrorum') [cf. Fig. 10.22].110 The wording Benedicti chooses is particular: it comes from from Virgil's Aeneid, the epos about the Trojan founder of Rome, Aeneas. The quotation is taken from the mouth of the Roman chief god, Jupiter, who predicts that 'from the noble blood of Teucer a people will some day arise which

109 Benedicti, "Philippus Rex Hispaniae", in: ibidem, ch. Xxxvı, p. 154.

110 Ibidem, ch. I. 
will rule Italy' ('Italiam regeret genus alto a sanguine Teucri', Aeneid IV, 228229). Teucer is the ancestor and national hero of the Trojans, whom Virgil also calls the Teucri ('people of Teucer'). That Benedicti should say the same about Dirk I as Virgil does about Aeneas indicates that he is likening the founder of the County of Holland to the founder of Rome.

\section{8}

\section{Petrus Scriverius}

The Leiden scholar Petrus Scriverius (1576-166o), already mentioned several times in the present work, played a key role in the production of series of portraits of the Counts of Holland. He published no fewer than six series during his lifetime, in both Latin and Dutch; the first was dated 1609, the last $165^{0}$. Scriverius (a Latinisation of the surname Schrijver) came from a well-to-do Haarlem family and studied in Leiden, where he remained after graduation.111 He felt at home in the humanist environment of Leiden professors and scholars. Although he never obtained a chair or other academic appointment, he devoted his whole life to scholarship. He had a pronounced interest in antiquariansm, neo-Latin poetry and above all national history.112 Scriverius had accumulated a celebrated library, which he called his 'musaeum' ('temple of the Muses'). Through his publications, he was keen to give a wider public access to the works he had collected. Scriverius was not remarkable as an original writer; he preferred to function as a collector and publisher of various kinds of texts, especially neo-Latin poetry and works of history. Most of the books he published, therefore, were the works of other authors. The problem is that he does not always indicate what is his own text and what is not. Scriverius tends to deliver only small gobbets of commentary on his collated material. $\mathrm{He}$ prefers to make his 'sources' accessible than to voice his own opinions about them in print.

These propensities also play a major role in his publications on the Counts of Holland. ${ }^{113}$ In the first editions, those of 1609 and 1611 , almost all his texts are derived from other authors. He combined the Latin epigrams (epitaphia) of Georgius Benedicti with the prose chapters of Hadrianus Barlandus, and fragments from Jacob Meier's chronicle with brief explanatory notes which he had

111 For Scriverius's biographical details, see Langereis S., Geschiedenis als Ambacht. Oudheidkunde in de Gouden Eeuw: Arnoldus Buchelius en Petrus Scriverius, Hollandse Studiën 37 (Hilversum: 2001) 104-112.

112 For Scriverius as an antiquary and keen national historian, cf. ibidem, $112 \mathrm{ff}$.

113 For his series of counts, cf. ibidem, $255^{-264}$. 
copied from Plantin's edition of the 1584 Hollandiae comitum historia et icones. ${ }^{114}$ However, he leaves the reader in the dark about this, so that it remains opaque which authors wrote which sections of the text. There is only one exception: the quotations from Meier's chronicle (which, in fact, Scriverius had also retrieved from Plantin's edition, not taken direct from source) are given a succinct sub-heading stating the author's name. Many readers will have assumed that Scriverius himself had penned the rest of the book. Modern historians long continued to think the same, until around the year 2000. ${ }^{115}$ The aim here is not to imply that Scriverius was a plagiarist, but it is necessary to give this background to his method of working and to show how his series of the counts was composed. The key consideration is that the texts he used were ones which he believed important to be noted by the intellectuals of his age.

Not by chance was his collection of sources on the ancient history of Holland, the Batavia illustrata, his first major publication. ${ }^{116}$ The series on the counts, Illustrissimorum Hollandiae Zelandiaeque comitum ac dominorum Frisiae icones et historia, is a component of that work. Scriverius thought that it was an apt moment in 1609 to present the counts to the general public. The main reason behind his decision was the political situation during the Twelve Years' Truce, which was officially promulgated on 9 April that year. This indicated de-facto acknowledgement that the rebel provinces now formed an independent state. England and France immediately entered into diplomatic relations with the United Provinces; other states followed later. Scriverius thought that his history would go down very well in this climate: the time had come to foster in Holland an independent historical consciousness and a sense of national pride and independence. Scriverius expresses this thinking in the dedicatory letter to his Batavia illustrata, which he appropriately dedicates to the States of Holland and West-Friesland. It is in this light that we must interpret the publication of his series: as a national portrait gallery intended to serve as a source of national identity. The Truce took effect on 9 April and by

114 See following footnote.

115 E.g. Tuynman P., "Petrus Scriverius. 12 January 1576-30 April 166o", Quaerendo 7 (1977) 4-45, and Haitsma Mulier - van der Lem (eds.), Repertorium 376, under no. 436b, where we read that the texts accompanying the woodcuts of the Illustrissimorum Hollandiae Zelandiaeque comitum ac dominorum Frisiae icones et historia were a Latin 'adaptation' by Scriverius of a text whose title is given as 'Duym's History of the Counts of Holland, Zeeland and Friesland'. Langereis, Geschiedenis als Ambacht 125, rightly points out that these were texts which Scriverius had taken from Plantin's edition of 1584, particularly of Barlandus's Principes Hollandiae. However, Langereis does not mention the poems by Georgius Benedicti, which incidentally were not included in Plantin's edition. Scriverius took these from the 1586 Leiden edition, published by Benedicti himself.

116 Leiden, Lodewijk Elzevier: 16og. 
early June, Scriverius already had his large collection of sources of national history ready to hand. His letter of dedication to the States of Holland and West-Friesland is dated 13 June.

As an historian, Scriverius was not very keen on the Trojans. He was sceptical of the family tree claims which he encountered in the chronicles. In the 1609 Batavia illustrata and its 1611 second edition, the Inferiores Germaniae provinciarum unitarum antiquitates, however, he refrains from giving an opinion on their veracity. Since Scriverius reproduces in these works Benedicti's epigrams on the counts, however, the Trojan forefathers are still present in these series. The same applies, in fact, to the last series which appeared during Scriverius's lifetime, that of $1650.1{ }^{117}$ Contemporary politics again played a role in the compiling of this edition. The 1648 Peace of Münster had ensured the recognition of the rebel Netherlands as a fully-fledged state. It was now time, then, to celebrate the glorious achievement and further burnish national pride. In collaboration with the Haarlem painter and printmaker Pieter Soutman (c. 1580-1657) and the young but extremely talented engraver Cornelis Visscher (1629-1658) [Fig. 10.28], Scriverius brought out the most sumptuous edition of

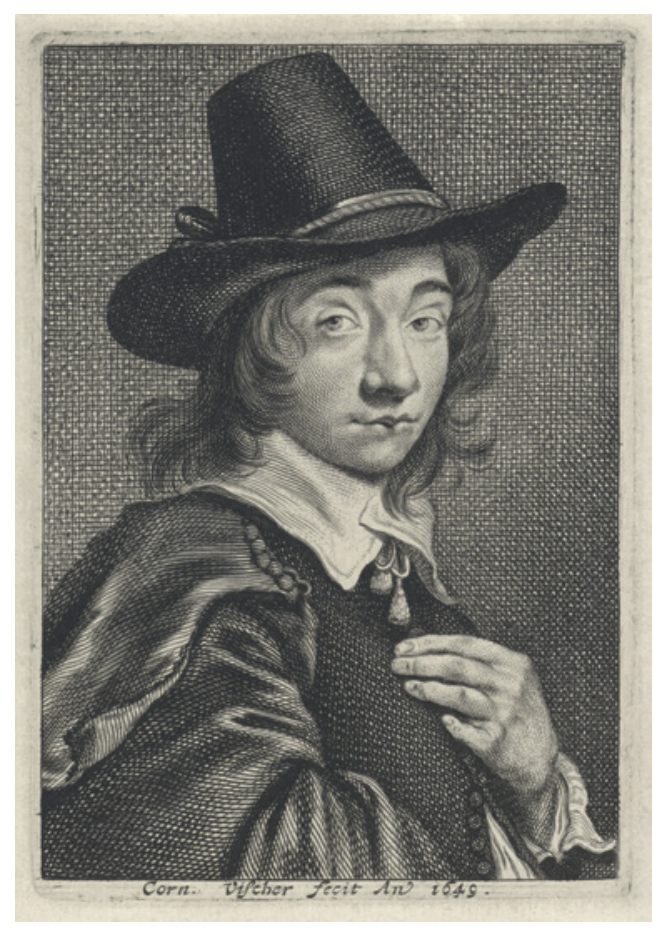

FIGURE 10.28

Cornelis Visscher, Self-portrait (1649). Engraving IMAGE (C) RIJKSMUSEUM, AMSTERDAM

117 Scriverius Petrus, Principes Hollandiae et Westphrisiae (Haarlem, Pieter Soutman: 1650). 
the Counts of Holland that one could imagine. The portrait series, printed in prestigious folio format, was now being presented as a national monument to the eternal memory of the counts, as well as serving to celebrate national independence. The monumental character of this series is underlined by the colossal inscription of honour in antique Roman style [Fig. 10.32]. Here, the counts are addressed as one would address a deity in Roman times. Just as one 'offered' and 'dedicated' gifts to the gods in antiquity, so this inscription ends with the religious formula 'offert, dedicat et consecrat'. In this sense, the counts had become the subject of a divine cult. Scriverius and Soutman erected this monument to the counts to have them praised as superhuman national cult figures.

Accordingly, the title page depicts an apotheosis (deification): the counts, and with them the Province of Holland for which they stand (represented by the arms of its key cities), are made divine [Fig. 10.29]. The representation oozes the new national self-confidence. Victorious Hollandia's garden is full of arms. It would appear that Holland has brought the whole world under her sway: behind the personification of her as a young woman, we see the globe, upon which her heraldic animal, a realistically-depicted, giant lion, has rested his front left paw to demonstrate his might and lordship. With typological significance, the central figure, young Lady Holland, makes the same gesture: she, too, lays her left hand on the globe as a token of her supremacy. This imperialist impression is reinforced by the presence of an angel, holding a crown atop Lady Hollandia. In this way, Lady Hollandia is unmistakably characterised as an imperial ruler. In her right hand, she holds an ocean-going ship to symbolise Dutch supremacy at sea. She is seated on a powerful canon bearing an inscription which makes plain why it is being triumphantly fired. It reads 'Haec libertatis ergo' - 'This on account of freedom'. The cities of Holland (represented by their arms) and her counts (represented by the titular inscription and by the crowns) are conveyed to heaven by the angels. This portrayal is of great political import: the counts are deified here like Roman Caesars, thereby acquiring imperial status, one to which the province too (since it is embodied by the counts) lays claim.

Cornelis Visscher's engravings are highly refined. Although Visscher cannot of course have had the faintest idea what the pre-140o counts looked like, his engravings were meant to suggest that the portrayals were 'real' and authentic, 'true to life', as the title page asserts. As regards their form, however, the counts are still Trojans, as we see from Dirk I's fantastical oriental turban. Notwithstanding this, his face sems to radiate some personal characteristics. As noted earlier, there was (and still is) no indication of Dirk's true appearance. A curious detail is that the son of the Aquitanian Trojan Sigisbertus, 


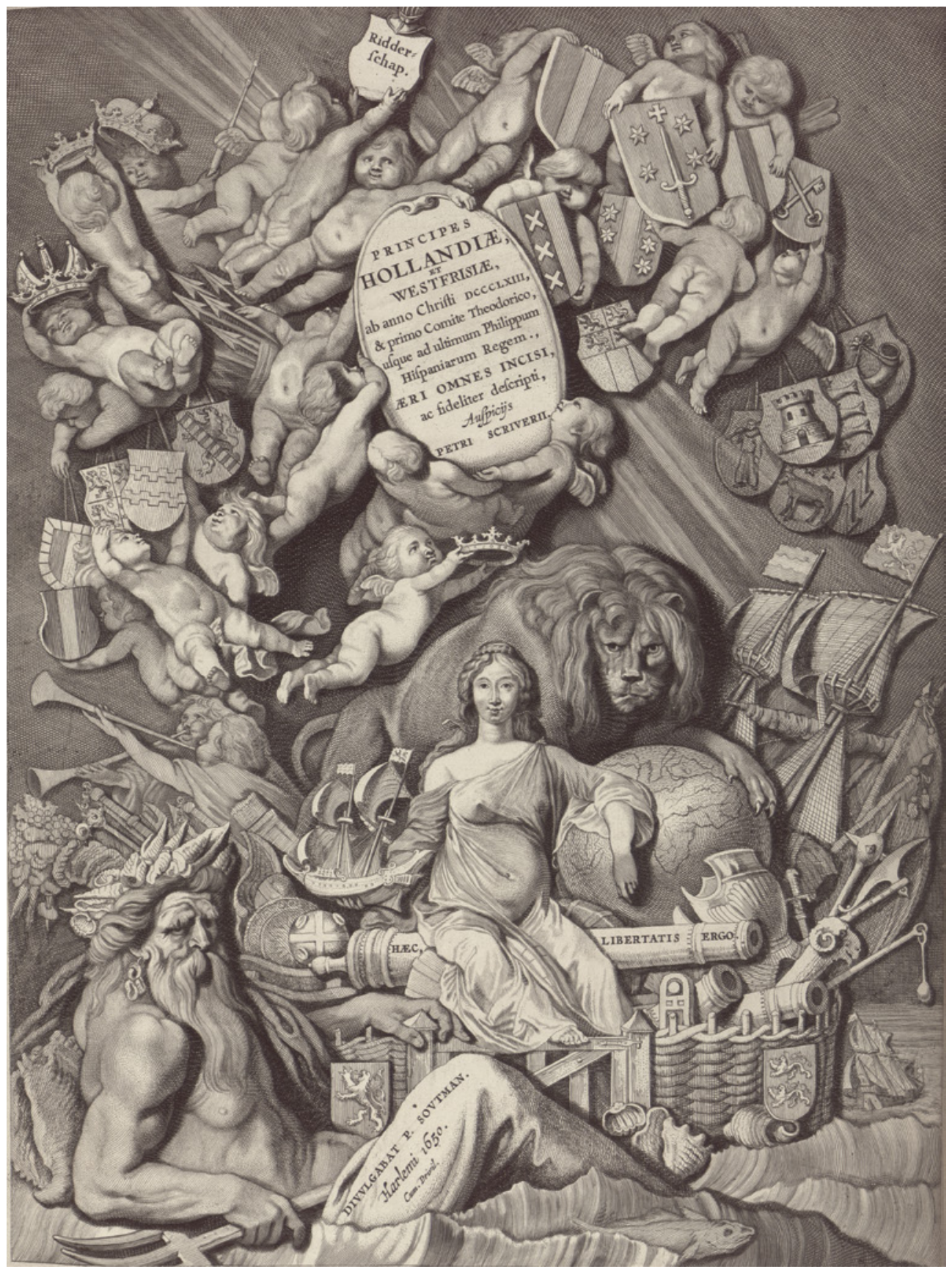

FIGU Re 10.29 Frontispice of Petrus Scriverius, Principes Hollandiae [...] (Haarlem: 1650) (C) RIJKSMUSEUM, AMSTERDAM 


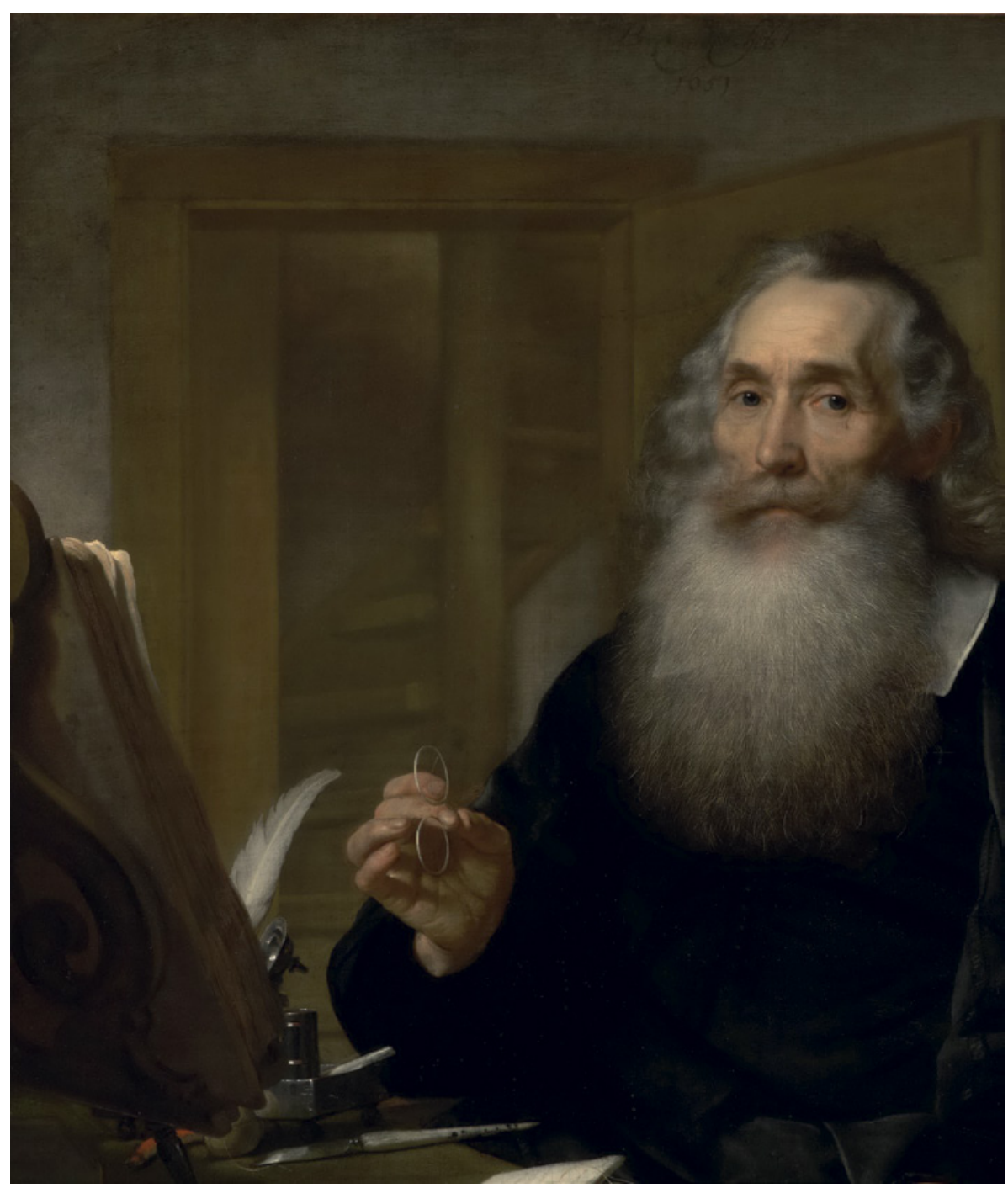

FIG URE 10.30 Bartolomeus van der Helst, Portrait of Petrus Scriverius (1651). Oil on canvas, $115.2 \times 98.5 \mathrm{~cm}$

IMAGE (C) MUSEUM DE LAKENHAL, LEIDEN 


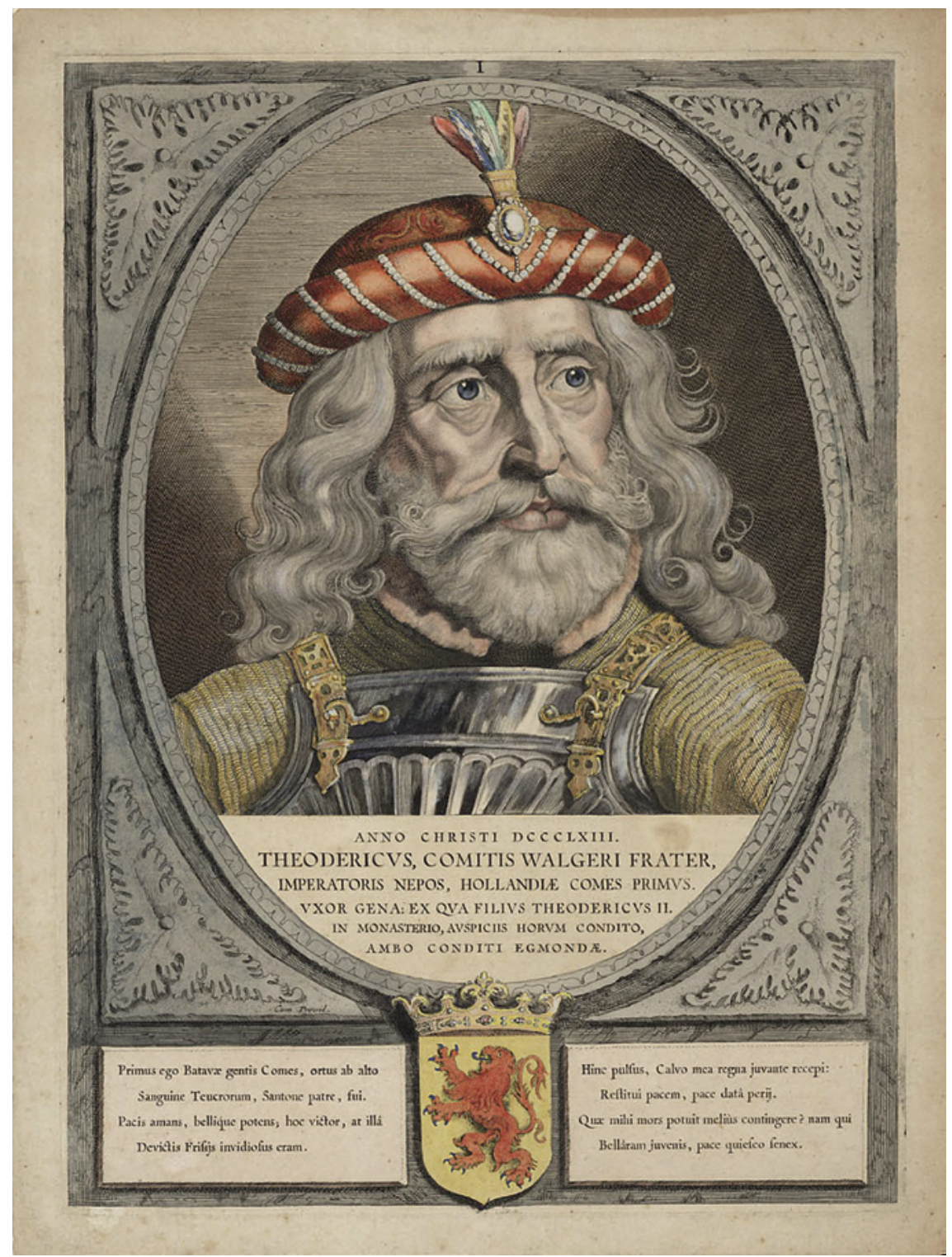

FIGURE 10.31 Dirk I, Count of Holland. Engraving by Cornelis Visscher II (1650), in Petrus Scriverius, Principes Hollandiae [...] (Haarlem: 1650)

IMAGE (C) RIJKSMUSEUM, AMSTERDAM 


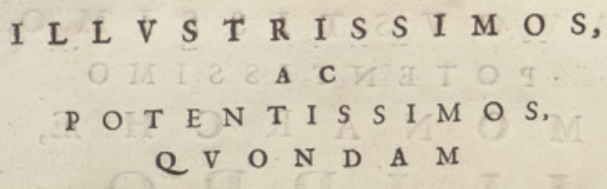

\section{HOLLANDIE, ZEELANDIE, FRISI压}

\section{$\begin{array}{lllllllll}P & R & I & N & C & I & P & E & S\end{array}$}

OPERAVIVERSORVM PICTORVM

OLIM AD VIVVM DEPICTOS, NVNC AVTEM OMNES VSQVE AD VLTIMVM,

I $O$ SVM P TIB VS, ET DIRECTIONE

P. SOVTMANNI HARLEMENSIS,

P I C TOR I S QVONDA M

SIGISMVNDI III POLONORVM REGIS

$P$ O T E N T I S S I M I;

AVGVSTA, ET ARTIFICIOSA ADMODVM FORMA,

CERI INCISOS; ET INDVSTRIA

P. $S C R \quad I \quad V \quad R \quad I$

C E LEBERRIMI HISTORIOGRAPH I

EX ANTIQVIS INCORRVPTE FIDEI

ANNALIBVS MANVSCRIPTIS, ET ARCHIVIS,

$S V M M A C V M$ FIDE DESCRIPTOS;

IN PERPETVAM HORVM NOBILISSIMORVM

PR I N I P V M M E M OR I A M,

A C I N VI PERPET V I

CVLTVS MONVMENTVM

I D E M

P. S O V T M A N N V S

$V$ E N E R A B V N D V S

OFFERT, DICAT, C ONSECRAT.

FIGURE 10.32 Dedication (inscription) of Petrus Scriverius, Principes Hollandiae [...]

(Haarlem: 1650)

IMAGE (C) UTRECHT UNIVERSITY LIBRARY 
the renowned Dirk I, bears a striking resemblance to the series author, Petrus Scriverius, in his latter years [Figs. 10.31 and 10.32]. It may be that Cornelis Visser portrayed Dirk so in honour of Scriverius, or at the least as a nod to him. If so, then Scriverius, the patriotic historian, lent his facial features to the supposed Trojan founder of the lineage of Counts of Holland.

\section{Selective Bibliography}

Acker K.G., "Iconografische beschouwingen in verband met de 16e eeuwse gegraveerde 'portreten' der graven van Vlaanderen", Oud-Holland 83 (1968) 95-116.

Anrooij W. van, "Aquitanië en de herkomst van de Hollandse graven, een 14e-eeuwse traditie", in Boer D.E.H. de - Cordfunke E.H.P. - Hugenholtz F.W.N. (eds.), Holland in wording. De ontstaansgeschiedenis van het graafschap Holland tot het begin van de vïftiende eeuw, Muiderberg symposia 5 (Hilversum: 1991) 125-142.

Anrooij W. van, "Middeleeuwse sporen van de Haarlemse Damiate-legende", in Grootes E.K. (ed.), Haarlems Helicon. Literatuur en toneel te Haarlem vó́r 1800 (Hilversum: 1993) 11-25.

Anrooij W. van (ed.), De Haarlemse gravenportretten. Hollandse geschiedenis in woord en beeld (Hilversum: 1997).

Barlandus Hadrianus, De Hollandiae principibus (Antwerp, Johannes Theobaldus: 1519). Barlandus Hadrianus, Libelli tres [...] uno principum Hollandiae, altero episcoporum insignis ecclesiae Traiectensis, tercio res gestae continentur invictissimi principis Caroli Burgundiae ducis [...] (Antwerp, Michael Hillenius: 1520).

Barlandus Hadrianus, Catalogus comitum Hollandiae (Amsterdam, Doen Pieterz.: 1519/ 1520).

Barlandus Hadrianus, Hollandiae Comitum historia et icones. Cum selectis scholis ad lectoris usum [...] (Leiden, Christopher Plantin: 1584).

Barlandus Hadrianus, Hollandiae Comitum historia et icones [...] (Frankfurt a.M., Johannes Wechel for Sigmund Feyerabend: 1585).

Beelaerts van Blokland W.A., "Stamreeksen in beeld. De graven van Holland en de heeren van Brederode door Jacob Cornelisz. van Oostzanen en Cornelis Anthonisz.", De Nederlandse leeuw 51 (1933) 202-207.

Benedicti Georgius, see Wertelos, Georgius Benedicti.

Boer D.E.H. de - Cordfunke E.H.P., Graven van Holland. Portretten in word en beeld (880-1580) (Zutphen: 1995).

Bueren T. van, "Van karmelietenklooster naar stadhuis", in Anrooij W. van (ed.), De Haarlemse gravenportretten. Hollandse geschiedenis in woord en beeld (Hilversum: 1997) 73-77. 
Buscher H., Heinrich Pantaleon und sein Heldenbuch (Diss. Basel: 1946), Basler Beiträge zur Geschichtswissenschaft, vol. 26.

Carasso-Kok M., Repertorium van verhalende historische bronnen uit de Middeleeuwen. Heiligenlevens, annalen, kronieken en andere in Nederland geschreven verhalende bronnen, Bibliografische reeks van het Nederlands Historisch Genootschap 2 (The Hague: 1981).

Dek A.W.E., Genealogie der graven van Holland (Zaltbommel: 1969).

Falkenburg R., "Politiek en propaganda omstreeks 149o", in Anrooij W. van (ed.), De Haarlemse gravenportretten. Hollandse geschiedenis in woord en beeld (Hilversum: 1997) 69-72.

Galle Philip, Imagines L doctorum virorum qui bene de studiis literarum meruere (Antwerp, Philip Galle and Franciscus Raphelengius: 1587).

Galle Philip - Vosmeer Michiel, Principes Hollandiae en Zelandiae, domini Frisiae [...]. Cum genuinis ipsorum iconibus [...] (Antwerp, Christopher Plantin for Philip Galle: 1578).

Galle Philip, Les vies et alliances des comtes de Hollande et Zélande, signeurs de Frise (Antwerp, Christopher Plantin: 1583 and 1586).

Giovio Paolo, Elogia virorum bellica virtute illustrium (Basel, Petrus Perna: 1575).

Giovio Paolo, Elogia virorum literis illustrium (Basel, Petrus Perna: 1575).

Gruterus Janus, Chronicum chronicorum politicum, in quo Imperatores, Reges, Duces, Principes, Marchiones etc. recensentur [...] (Frankfurt a.M., officina Aubriana: 1614).

Gruterus Janus, Delitiae C poetarum Belgicorum, huius superiorisque aevi illustrium (Frankfurt a.M., officina Aubriana: 1614).

Haitsma Mulier E.O.G. - Lem G.A.C. van der (eds.), Repertorium van geschiedschrijvers in Nederland (The Hague: 1990).

Jong J. de, "Gravenportretten in de zestiende en zeventiende eeuw", in Anrooij W. van (ed.), De Haarlemse gravenportretten. Hollandse geschiedenis in woord en beeld (Hilversum: 1997) 78-102.

Kurtz G.H. (ed.), "De afbeeldingen der graven en gravinnen van Holland op het stadhuis te Haarlem", Jaarboek Haerlem (1958) 40-58.

Keesman W., "Troje in de middeleeuwse literatuur. Antiek verleden in dienst van eigen tijd", Literatuur 4 (1987) 257-265.

Keesman W., De eindeloze stad. Troje en de Trojaanse oorsprongsmythen in de (laat)middeleeuwse en vroegmoderne Nederlanden (Hilversum: 2017).

Langereis S., Geschiedenis als Ambacht. Oudheidkunde in de Gouden Eeuw: Arnoldus Buchelius en Petrus Scriverius, Hollandse Studiën 37 (Hilversum: 2001).

Levy-van Halm K. - Runia E. - Sliggers B. et al. (eds.), De trots van Haarlem. Promotie van een stad in kunst en historie (Haarlem: 1995).

Lulofs M., 'Die van Brero heeft men eens gezien. De 'Brederode-kroniek' van Jan van Leyden”, in Ebels-Hoving B. - Santing C.G. - Tilmans C.P.H.M. (eds.), Genoechelijcke 
ende lustige historiën. Laatmiddeleeuwse geschiedschrijving in Nederland (Hilversum: 1987) 79-99.

Martindale A., Heroes, ancestors, relatives and the birth of the portrait (Maarssen: 1988). Nijhoff W., "De graven van Holland, houtsneden van Jacob Cornelisz, met Franse tekst. Amsterdam, Doen Pieterszoon, 1518", Het boek 25 (1938-1939) 51-52.

Overvoorde J.C., "De portretten der Hollandsche graven in het stadhuis te Leiden", in Hofstede de Groot C. (ed.), Feest-bundel dr. Abraham Bredius aangeboden den achttienden april 1915, vol. I: Opstellen (Amsterdam: 1915) 221-229.

Pantaleon Heinrich, Prosopographia heroum atque illustrium virorum totius Germaniae opus plane novum [...], ex omnium fere gentium chronicis, annalibus et historiis magna diligentia excerptum et vivis heroum imaginibus [...] illustratum, ac nunc primum ob patriae decorem in lucem editum, ita quod instar continuae historiae Germanorum esse queat [...] (Basel, Nicolaus Brylinger: 1565).

Pantaleon Heinrich, Teutscher Nation Heldenbuch: Inn diesem werden aller Hochuerrümpten Teutschen Personen, Geistlicher vnd Weltlicher, hohen vnnd nideren staths, Leben vnnd nam $[\mathrm{m}]$ hafftige thaten gantz warhaftig beschriben, welliche durch jhre tugendt, grosse authoritet, starcke waffen, from $[m]$ keit, weißheit, vnd gute künst [...] jr vatterland Teutsche nation höchlich bezieret, vnd groß gemachet; Mit sampt aller alten vnd neuwen Fürsten Teutscher nation Genealogey, Geburtstafflen vnd harkommen (Basel, Nicolaus Brylinger: 1567; heirs of Nicolaus Brylinger: 1570).

Pantaleon Heinrich, Der ander Theil Teutscher Nation Heldenbuch: Inn diesem werden aller hochberümpten Teutschen Personen, Geistlicher und Welticher, hohen unnd nideren staths, Leben unnd namhaffte Thaten gantz warhafftig beschrieben [...] von dem Grossen Carolo [...] har, in die siebenhundert jar, biss auff Keyser Maximilian den ersten [...] / Erstlich durch den Hochgelerten Herren Heinrich Pantaleon fast auss aller voelckeren Historien [...] fleissig in Latein zusammen gezogen, unnd mit sampt aller beschribener personen büldtnussen [...] künstlich fürgestellet. Jetzmalen aber von dem [...] Authore selbs verteutschet, reichlich gemehret, und gebesseret [...] (Basel, heirs of Nicolaus Brylinger: 1568).

Pantaleon Heinrich, Der dritte und letste Theil Teutscher Nation Heldenbuch: In diesem werden aller hochberümpten Teutschen Personen, Geistlicher und Weltlicher, hohen und nideren staths, Leben und nammhaffte Thaten gantz waarhafftig beschrieben [...] under den vier letsten Keyseren Maximilian I. Carolo V. Ferdinando, und Maximilian II.von dem 1500 biss auff das lauffende 1570 jar [...] / Erstlich durch den Hochgelehrten Herren Heinrich Pantaleon, zum theil auss vieler voelckeren Historien [...] in Latein zusamen gebracht, und mit sampt vieler personen bildnussen fürgestellet. Jetzmalen aber von dem Authore selbs verteutschet, reichlich gemehret, geenderet, und gebesseret [...] (Basel, heirs of Nicolaus Brylinger Erben: 1570).

Pantaleon Heinrich, Teutscher Nation warhafften Helden, Erstlich durch den Hochgelehrten Herren Heinrich Pantaleon, fastauß vieler völckern Historien, 
Chronecken, und geschichtrodlen, mit grosser arbeit fleissig zu Latein zusammen gezogen, und mit sampt aller beschriebener personen bildnussen (so viel möglich) künstlich fürgestellet. Jetzmalen aber von dem ersten Authore selbs verteutschet, reichlich gemehret, und gebesseret, auch zu lob Teutscher Nation inn Truck verfertiget. Also das der gemeine mann alle Teutschen Historien, von anfang der welt biß zu gemeldeter zeit, inn fürgestelleten Personen leichtlich vermercken. Allen Fürstlichen, Hohen Rittermeßigen, und Adelspersonen Teutscher nation gantz lustig, kurtzweilig, und nutzlich von iren altvorderen und vorfaren zulesen (Basel, Oststein: 1578).

Pelc M., Illustrium imagines. Das Porträtbuch in der Renaissance (Leiden - Boston: 2002).

Pelinck E., "De gravenramen van Willem Thybout en andere merkwaardigheden van de Leidse Doelens", Jaarboekje voor geschiedenis en oudheidkunde van Leiden en omstreken 43 (1951) 77-93.

Rave P.O., "Paolo Giovio und die Bildnisvitenbücher des Humanismus”, Jahrbücher der Berliner Museen 1 (1959) 119-154.

Romein J., "De functie van een historische fictie. De vermeende afstamming der Germanen uit Troje in verband met het begrip der translation imperii", in Romein J. (ed.), Het onvoltooid verleden. Cultuurhistorische studies (Amsterdam:1948) 209-220.

Ruyven-Zeman Z. van, "Willem Thybaut", in Luijten G. - Suchtelen A. van Baarsen R. et alii (eds.), The Dawn of the Golden Age. Northern Netherlandish Art 1580-1620 (Zwolle: 1993) 493-500 [exhibition catalogue Rijksmuseum Amsterdam].

Schepper M. de, "Quem patrem patriae voluit/(Deus): Georgius Benedicti Wertelos over Willem van Oranje", Hermeneus 56 (1984) 244-245.

Scriverius Petrus, Batavia illustrata [...] (Leiden, Ludovicus Elzevir: 16og; 1611).

Scriverius Petrus, Illustrissimorum Hollandiae Zelandiaeque Comitum ac dominorum Frisiae Icones et historia, in idem, Batavia illustrata [...] (Leiden, Ludovicus Elzevir: 1609; 1611) 1-184.

Scriverius Petrus, Principes Hollandiae et Westphrisiae (Haarlem, Pieter Soutman: 1650). Smit C.G.M., "Pieter Langendijk, 'De graaven van Holland' (1745). Een dichter verstrikt tussen pacifisme en vaderlandsliefde", in Grootes E.K. (ed.), Haarlems Helicon. Literatuur en toneel te Haarlem vóór 1800 (Hilversum: 1993) 163-175.

Tuynman P., "Petrus Scriverius. 12 January 1576-30 April 166o", Quaerendo 7 (1977) 4-45. Verheyen R.A.M., "Graven en gravinnen, getekend en vertekend. Een beschouwing over het vroege Hollandse vorstenportret", in Duindam H.F.J. (ed.), Holland in de dertiende eeuw. Leven, wonen en werken in Holland aan het einde van de dertiende eeuw (The Hague: 1982) 50-69.

Vogelaar C., "De gravenramen door Willem Thybaut", Lakenhal nieuws 1,9 (1996).

Volmert M., Grenzzeichen und Erinnerungsräume. Holländische Identität in Landschaftsbildern des 15.-17.Jahrhunderts (Berlin - New York: 2013). 
Vosmeer Michiel - Galle Philip, Principes Hollandiae en Zelandiae, domini Frisiae [...]. Cum genuinis ipsorum iconibus [...] (Antwerp, Christopher Plantin for Philip Galle: 1578).

Ward J.P., "Hadrianus Barlandus and a Catalogue of the Counts and Countesses of Holland Published at Amsterdam by Doen Pietersz", Humanistica Lovaniensia 55 (2006) 71-110.

Wertelos, Georgius Benedicti, Poemata posthuma, in quis Epigrammata, Epitaphia, Elegiae, ed. Petrus Scriverius (Leiden, Christoph Guyot: 1601).

Wertelos, Georgius Benedicti, Carmina quaedam in funere Guilielmi, Principis Arausionensis, Delphis parricidali manu occisi anno LXXXV [sic]. Additus est Epigrammatum libellus (Delft, Albertus Henricus: 1585).

Wertelos, Georgius Benedicti, De rebus gestis Principis Guilielmi comitis Nassovii, Principis Nassovii, libri duo. Item Epinicia, Epigrammata varia et Epitaphia comitum Hollandiae (Leiden, Joannes Paetsius: 1585).

Weissman A.W., "De portretten der graven van Holland te Haarlem", Oud-Holland 35 (1917) 61-70.

Winter J.M. van, "Willem Thybaut en de Hollandse gravenportretten", Spieghel historiael 6 (1971) 614-623. 